Prepared in cooperation with the city of Portland, the city of Gresham, the city of Milwaukie, Clackamas County's Water Environment Services, and Multnomah County

\title{
Hydrology of the Johnson Creek Basin, Oregon
}

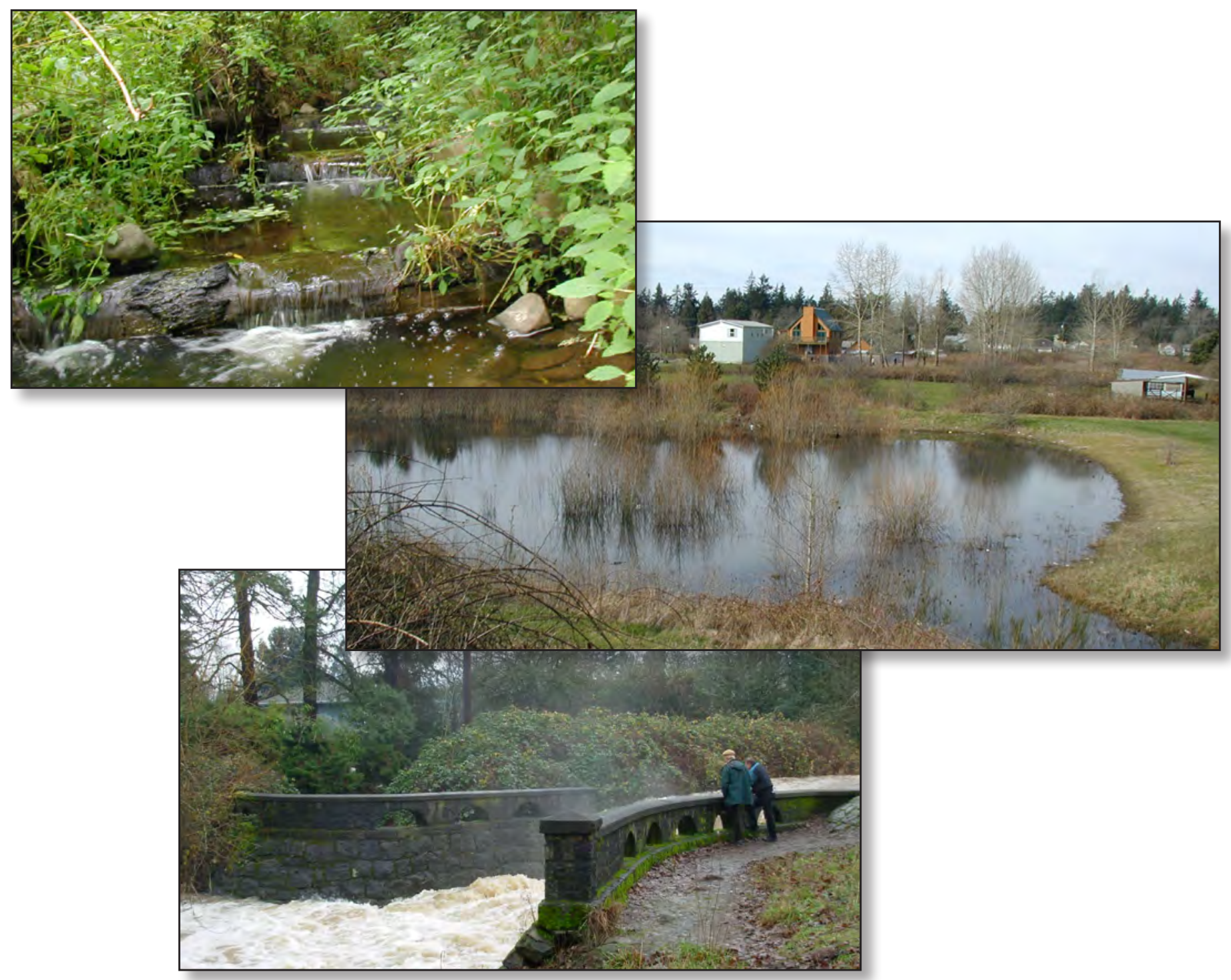

Scientific Investigations Report 2009-5123

U.S. Department of the Interior

U.S. Geological Survey 
Cover:

Top: Photograph of Crystal Springs Creek at Reed College, Portland, Oregon, July 6, 2005.

Middle: Photograph of Holgate Lake at Portland, Oregon, March 13, 2006.

Bottom: Photograph of Johnson Creek at Portland, Oregon, December 25, 2006.

Photographs taken by Karl K. Lee, U.S. Geological Survey. 


\section{Hydrology of the Johnson Creek Basin, Oregon}

By Karl K. Lee and Daniel T. Snyder

Prepared in cooperation with the city of Portland, the city of Gresham, the city of Milwaukie, Clackamas County's Water Environment Services, and Multnomah County

Scientific Investigations Report 2009-5123 


\title{
U.S. Department of the Interior \\ KEN SALAZAR, Secretary \\ U.S. Geological Survey \\ Suzette M. Kimball, Acting Director
}

\section{U.S. Geological Survey, Reston, Virginia: 2009}

\author{
For more information on the USGS — the Federal source for science about the Earth, its natural and living resources, \\ natural hazards, and the environment, visit http://www.usgs.gov or call 1-888-ASK-USGS \\ For an overview of USGS information products, including maps, imagery, and publications, \\ visit http://www.usgs.gov/pubprod \\ To order this and other USGS information products, visit http://store.usgs.gov
}

Any use of trade, product, or firm names is for descriptive purposes only and does not imply endorsement by the U.S. Government.

Although this report is in the public domain, permission must be secured from the individual copyright owners to reproduce any copyrighted materials contained within this report.

Suggested citation:

Lee, K.K., and Snyder, D.T., 2009, Hydrology of the Johnson Creek basin, Oregon: U.S. Geological Survey Scientific Investigations Report 2009-5123, 56 p. 


\section{Contents}

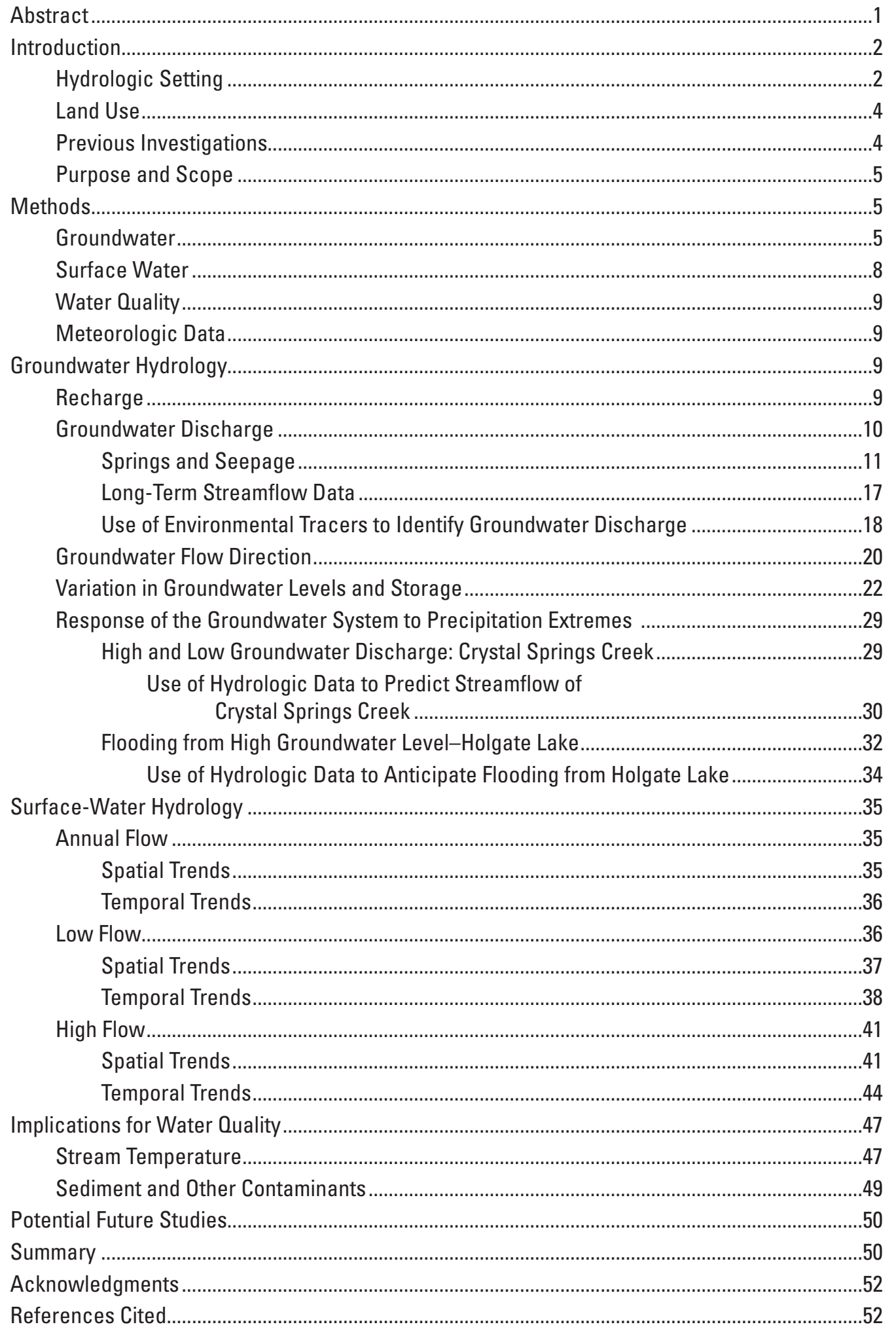




\section{Plate}

Plate 1. Map showing location of groundwater and surface-water sites in the Johnson Creek basin, Oregon.

\section{Figures}

Figure 1. Map showing location of the Johnson Creek basin, Oregon

Figure 2. Graph showing streamflow measurements of Crystal Springs Creek at Reed College, measurements and estimates of streamflow at the mouth of Crystal Springs Creek, and measurements of Errol Spring Creek, Portland, Oregon

Figure 3. Graph showing relation between average measured streamflow at the mouth of Crystal Springs Creek, Portland, Oregon, and consecutive 7-day average low streamflow of Johnson Creek at Milwaukie, Oregon, August to October 1989, 1997-2006

Figure 4. Graph showing seepage measurements during low flow in 1988, 1997-2000, 2006, and specific conductance measurements during low flow in 1998, 1999, and 2006, Johnson Creek, Oregon

Figure 5. Graph showing annual, 3-year average, and cumulative departure from average precipitation at Portland Airport, Oregon, 1911-2006

Figure 6. Graph showing gain in consecutive 7-day average low streamflow between Johnson Creek at Regner Road at Gresham, Oregon, and Johnson Creek at Sycamore, Oregon, and between Johnson Creek at Sycamore and Johnson Creek at Milwaukie, Oregon

Figure 7. Graph showing temperature at river mile (RM) 7.8, RM 5.5, and RM 3.2, Johnson Creek, Oregon

Figure 8. Map showing estimated water table elevation, Johnson Creek basin, Oregon..... 21

Figure 9. Hydrographs showing water levels in selected long-term observation wells, Johnson Creek basin, Oregon

Figure 10. Graphs showing water level elevation and depth to water in wells: near 133rd Avenue and Raymond Street, at Brentwood Park, at Woodstock Park, and at Berkeley Park, Portland, Oregon

Figure 11. Graphs showing precipitation at Portland Airport, Oregon, water level elevation in the shallow well at Westmoreland Park and water level of Johnson Creek at Milwaukie, Oregon, and water level elevation in the deep well at Westmoreland Park, and level of the Willamette River at Portland, Oregon

Figure 12. Graph showing relation between water level elevation in wells at Berkeley Park, and at 32nd Avenue and Steele Street, Portland, Oregon

Figure 13. Graph showing relation between streamflow of Crystal Springs Creek at Reed College and mouth of Crystal Springs Creek at Portland, and water level elevation in the well at Berkeley Park, Portland, Oregon

Figure 14. Graph showing water level elevation (1999-2006) of Holgate Lake at Portland, Oregon, in the well near 133rd Avenue and Raymond Street, in the well in the bed of Holgate Lake, in the well adjacent to Holgate Lake, and cumulative precipitation (from October to September each year) at Portland Airport, Oregon 


\section{Figures-Continued}

Figure 15. Graph showing relation between annual rise in water level in a well near 133rd Avenue and Raymond Street, Portland, Oregon, and cumulative precipitation at the Portland Airport, Oregon, from October 1 of each year to date of maximum water level in well, water years 1999-2006

Figure 16. Graph showing cumulative departure from annual mean streamflow of Johnson Creek at Sycamore, Oregon, water years 1941-2006, Johnson Creek at Milwaukie, Oregon, water years 1990-2006, and annual total precipitation at the Portland Airport, Oregon (site number 356751), water years 1941-2006 ..... 37

Figure 17. Graph showing flow duration curves of the upper area of Johnson Creek basin at Gresham, Oregon, of the middle basin between Johnson Creek at Gresham and Johnson Creek at Sycamore, Oregon, and of the lower basin between Johnson Creek at Sycamore and Johnson Creek at Milwaukie, Oregon, water years 1999-2006....

Figure 18. Graphs showing consecutive 7-day and 30-day average low streamflow of Johnson Creek at Sycamore, Oregon, and of Little Sandy River near Bull Run, Oregon

Figure 19. Graph showing flow duration curves based on water years 1941-1962 (early), water years 1963-1984 (middle), and water years 1985-2006 (later), Johnson

Creek at Sycamore, Oregon

Figure 20. Graph showing annual peak streamflow of Johnson Creek at Sycamore, and Johnson Creek at Milwaukie, Oregon

Figure 21. Graph showing flood frequency curves based on log-Pearson Type III probability distribution, Johnson Creek at Sycamore, Oregon, water years 1941-2006 and 1990-2006, and Johnson Creek at Milwaukie, Oregon, water years 1990-2006.

Figure 22. Graph showing rating curve in use during water year 2006, and annual peak stream level and streamflow from water years 1941 to 2006, Johnson Creek at Sycamore, Oregon .

Figure 23. Graph showing temperature of streams in the Johnson Creek basin, Oregon, May to October 2005

Figure 24. Graph showing estimated temperature of Johnson Creek at Gresham, Oregon, and Johnson Creek at Milwaukie, Oregon, based on air temperature at the Portland Airport, Oregon (site number 356751), 1998-2006

\section{Tables}

Table 1. Groundwater and surface-water sites in the Johnson Creek basin, Oregon

Table 2. Streamflow and specific conductance measurements used in seepage analysis, Johnson Creek, Oregon.

Table 3. Annual peak streamflow and volume, Johnson Creek, Oregon, water years 1990-2006

Table 4. Magnitude and probability of peak streamflow of Johnson Creek, Oregon 


\section{Conversion Factors, Datums, and Abbreviations}

Conversion Factors

\begin{tabular}{|c|c|c|}
\hline Multiply & By & To obtain \\
\hline \multicolumn{3}{|c|}{ Length } \\
\hline inch (in.) & 2.54 & centimeter (cm) \\
\hline inch (in.) & 25.4 & millimeter (mm) \\
\hline foot (ft) & 0.3048 & meter $(\mathrm{m})$ \\
\hline mile (mi) & 1.609 & kilometer (km) \\
\hline \multicolumn{3}{|c|}{ Area } \\
\hline square mile $\left(\mathrm{mi}^{2}\right)$ & 259.0 & hectare (ha) \\
\hline square mile $\left(\mathrm{mi}^{2}\right)$ & 2.590 & square kilometer $\left(\mathrm{km}^{2}\right)$ \\
\hline \multicolumn{3}{|c|}{ Volume } \\
\hline acre-foot (acre-ft) & 1,233 & cubic meter $\left(\mathrm{m}^{3}\right)$ \\
\hline acre-foot (acre-ft) & 0.001233 & cubic hectometer $\left(\mathrm{hm}^{3}\right)$ \\
\hline million gallons per day (Mgal/d) & 0.04381 & cubic meter per sec $\left(\mathrm{m}^{3} / \mathrm{s}\right)$ \\
\hline \multicolumn{3}{|c|}{ Flow rate } \\
\hline acre-foot per year (acre-ft/yr) & 1,233 & cubic meter per year (m³/yr) \\
\hline acre-foot per year (acre-ft/yr) & 0.001233 & cubic hectometer per year $\left(\mathrm{hm}^{3} / \mathrm{yr}\right)$ \\
\hline cubic foot per second $\left(\mathrm{ft}^{3} / \mathrm{s}\right)$ & 0.02832 & cubic meter per second $\left(\mathrm{m}^{3} / \mathrm{s}\right)$ \\
\hline $\begin{array}{l}\text { cubic foot per second per square } \\
\text { mile }\left[\left(\mathrm{ft}^{3} / \mathrm{s}\right) / \mathrm{mi}^{2}\right]\end{array}$ & 0.01093 & $\begin{array}{l}\text { cubic meter per second per square } \\
\text { kilometer }\left[\left(\mathrm{m}^{3} / \mathrm{s}\right) / \mathrm{km}^{2}\right]\end{array}$ \\
\hline inch per year (in/yr) & 25.4 & millimeter per year (mm/yr) \\
\hline \multicolumn{3}{|c|}{ Hydraulic gradient } \\
\hline foot per mile (ft/mi) & 0.1894 & meter per kilometer (m/km) \\
\hline
\end{tabular}

Temperature in degrees Celsius $\left({ }^{\circ} \mathrm{C}\right)$ may be converted to degrees Fahrenheit $\left({ }^{\circ} \mathrm{F}\right)$ as follows:

$$
{ }^{\circ} \mathrm{F}=\left(1.8 x^{\circ} \mathrm{C}\right)+32 .
$$

Specific conductance is given in microsiemens per centimeter at 25 degrees Celsius $(\mu \mathrm{S} / \mathrm{cm}$ at $\left.25^{\circ} \mathrm{C}\right)$.

Datums

Vertical coordinate information is referenced to the National Geodetic Vertical Datum of 1929 (NGVD 1929), or to the North American Vertical Datum of 1988 (NAVD 1988), as indicated in text, plate, figures, and tables.

Horizontal coordinate information is referenced to the North American Datum of 1927 (NAD 1927), or to the North American Datum of 1983 (NAD 1983), as indicated in text, plate, figures, and tables.

Elevation, as used in this report, refers to distance above the vertical datum. 
Abbreviations

$\begin{array}{ll}\text { Abbreviation } & \text { Meaning } \\ \text { DEM } & \text { Digital elevation model } \\ \text { GPS } & \text { Global Positioning System } \\ \text { NWIS } & \text { National Water Information System } \\ \text { NWS } & \text { National Weather Service } \\ \text { OWRD } & \text { Oregon Water Resources Department } \\ \text { PRISM } & \text { Precipitation Elevation Regressions on Independent Slopes Model } \\ \text { RM } & \text { River mile } \\ \text { TMDL } & \text { Total Maximum Daily Load } \\ \text { UIC } & \text { Underground injection control } \\ \text { USGS } & \text { U.S. Geological Survey } \\ \text { UTM } & \text { Universal Transverse Mercator } \\ \text { WY } & \text { Water year, the 12-month period from October 1 through September 30, } \\ & \text { and is identified by the calendar year in which it ends }\end{array}$


This page intentionally left blank. 


\title{
Hydrology of the Johnson Creek Basin, Oregon
}

\author{
By Karl K. Lee and Daniel T. Snyder
}

\section{Abstract}

The Johnson Creek basin is an important resource in the Portland, Oregon, metropolitan area. Johnson Creek forms a wildlife and recreational corridor through densely populated areas of the cities of Milwaukie, Portland, and Gresham, and rural and agricultural areas of Multnomah and Clackamas Counties. The basin has changed as a result of agricultural and urban development, stream channelization, and construction of roads, drains, and other features characteristic of human occupation. Flooding of Johnson Creek is a concern for the public and for water management officials. The interaction of the groundwater and surface-water systems in the Johnson Creek basin also is important. The occurrence of flooding from high groundwater discharge and from a rising water table prompted this study. As the Portland metropolitan area continues to grow, human-induced effects on streams in the Johnson Creek basin will continue. This report provides information on the groundwater and surface-water systems over a range of hydrologic conditions, as well as the interaction these of systems, and will aid in management of water resources in the area.

High and low flows of Crystal Springs Creek, a tributary to Johnson Creek, were explained by streamflow and groundwater levels collected for this study, and results from previous studies. High flows of Crystal Springs Creek began in summer 1996, and did not diminish until 2000. Low streamflow of Crystal Springs Creek occurred in 2005. Flow of Crystal Springs Creek was related to waterlevel fluctuations in a nearby well, enabling prediction of streamflow based on groundwater level.

Holgate Lake is an ephemeral lake in Southeast Portland that has inundated residential areas several times since the 1940s. The water-surface elevation of the lake closely tracked the elevation of the water table in a nearby well, indicating that the occurrence of the lake is an expression of the water table. Antecedent conditions of the groundwater level and autumn and winter precipitation totals were used to anticipate flooding of Holgate Lake.

Several factors affect annual mean flow of Johnson Creek. More precipitation falls in the southeastern area of the basin because of the topographic setting. Runoff from much of the northern and western areas of the basin does not flow into Johnson Creek due to permeable deposits, interception by combined sewer systems, and by groundwater flow away from Johnson Creek. Inflow from Crystal Springs Creek accounts for one-half of the increase in streamflow of Johnson Creek between the Sycamore and Milwaukie sites.

Low flows of Johnson Creek vary as a result of fluctuations in groundwater discharge to the creek, although past water uses may have decreased flows. The groundwater contributions to streamflow upstream of river mile (RM) 5.5 are small compared to contributions downstream of this point. Comparison of flows to a nearby basin indicates that diversions of surface water may have resulted in a 50 percent decrease in low flows from about 1955 to 1977.

Runoff from the drainage basin area upstream of the Johnson Creek at Sycamore site contributes more to peak streamflow and peak volume than the drainage basin area between the Sycamore and Milwaukie sites. The average increase in annual peak streamflow and annual peak volume between the two sites was 11 and 24 percent, respectively. Decreased contribution in the lower area of the drainage basin is a result of infiltration, interception by drywell and combined sewer systems, and temporary overbank storage.

Trends in flow typically associated with increasing urban development were absent in Johnson Creek. Annual, low, and high flows showed no trend from 1941 to 2006. Much of the infrastructure that may affect runoff from agricultural, residential, and urban development was in place prior to collection of hydrologic data in the basin. Management of stormwater in the urban areas by routing runoff from impervious surfaces to drywell and combined sewer systems may have affected runoff characteristics.

Understanding the distribution of runoff in the Johnson Creek basin helps protect water quality. Summer temperature of Johnson Creek and tributary streams is affected by groundwater discharge and by exposure of the stream to the surrounding atmosphere. Although groundwater discharge cools the stream in some reaches, other stream reaches with relatively shallow, unshaded ponds show warming. High flow in Johnson Creek may entrain sediment and sediment-borne contaminants. Management of runoff, especially in the eastern area of the basin, will maintain and improve the ecological health of Johnson Creek. 


\section{Introduction}

The Johnson Creek basin is located in northwestern Oregon on the eastern side of the Portland metropolitan area in Multnomah and Clackamas Counties. Johnson Creek is about $24 \mathrm{mi}$ long and has a surface-water drainage basin that covers an area of $54 \mathrm{mi}^{2}$. The surface-water drainage basin is defined by the surface-water flow divide - a ridge in the land surface from which surface water moves away in both directions perpendicular to the ridge line. Johnson Creek flows generally westward from agricultural areas near Boring, through residential and industrial areas in the cities of Gresham and Portland, and enters the Willamette River in the city of Milwaukie (pl. 1, fig. 1).

Record rainfall in water years (WY) 1996 and 1997 resulted in two types of flooding in the Johnson Creek basin. Intense rainfall in February and November 1996 led to flooding of Johnson Creek. The cumulative effect of 2 years of high annual precipitation led to groundwater flooding, manifested in high streamflow of Crystal Springs Creek - an entirely groundwater fed tributary to Johnson Creek; and an elevated water table in the vicinity of Holgate Lake. Although the flooding of Johnson Creek lasted on a time scale of several days, the groundwater flooding persisted for months to years. These flooding events revealed the interaction of the groundwater and surface-water systems, and the need for better understanding of the hydrology of the Johnson Creek basin.

In addition to better understand specific flooding events, information was needed about spatial and temporal trends in streamflow, and the interaction of the groundwater system and streams in the basin at low flow for the protection of water quality. The U.S. Geological Survey (USGS) began a study in 1997 with the city of Portland. In 2000, the cities of Gresham and Milwaukie, and Clackamas County's Water Environment Services joined the cooperative study, followed in 2002 by Multnomah County.

The Johnson Creek basin has a temperate marine climate in which winters typically are wet and summers are dry. About two-thirds of the annual precipitation is from November through March, and less than 10 percent from July through September. Most precipitation falls as rain. Although snow falls several times each year, accumulation is uncommon and usually melts rapidly during subsequent rain storms. Annual precipitation in the Johnson Creek basin increases to the southeast from about $40 \mathrm{in}$. at the mouth of the creek to more than $60 \mathrm{in}$. in the upland area of the basin. Average annual precipitation (WY 1911-2006) in Portland is about 37 in. (Oregon Climate Service, 2007).

\section{Hydrologic Setting}

The Johnson Creek basin is within the southern end of the Portland basin, a large topographic and structural depression that includes most of the Portland metropolitan area in northwestern Oregon and that extends across the Columbia River into southwestern Washington. The Johnson Creek basin is bounded on the south by the Clackamas River and Kellogg Creek basins. A subtle surface-water divide separates the Johnson Creek basin from the Sandy River basin to the northeast and the basins of the Columbia River and Fairview Creek to the north.

The hydrogeologic setting of much of the Portland metropolitan area, including the Johnson Creek basin, is summarized in Snyder (2008, p. 8-9). The study area can be divided into three areas where geology and soils have important effects on groundwater discharge and streamflow:

1. A group of volcanic buttes that are the western extent of Cascade volcanoes arise on the south side of the basin. The highest elevation is about 1,100 ft (Trimble, 1963). The largest tributary to Johnson Creek in the area is Kelley Creek. The greatest component of soils is the Cascade silt loam group (U.S. Department of Agriculture Natural Resources Conservation Service, 2007). The steep slopes and silty soils contribute to low infiltration and rapid runoff.

2. Consolidated sands and gravels underlie the Gresham area and the lowlands on the southern side of the creek east of I-205, which is Troutdale Formation as identified in McFarland and Morgan (1996, p. 9-11) and the "middle sedimentary unit" as identified by Conlon and others (2005, p. 15). Soils in the area are Powell and Cascade silt loams. The runoff characteristics of these soil types are similar to those in the area of the buttes, although the terrain is less steeply sloped.

3. The northern side of the basin west of Gresham and the southern side of the basin west of I-205 is a distinct contrast to the more steeply sloped, less-permeable areas to the south and east. Except for isolated volcanic buttes, the landscape is relatively flat and has terrace deposits that are identified as the "unconsolidated sedimentary aquifer" (McFarland and Morgan, 1996, p. 9-10) and the upper sedimentary unit (Conlon and others, 2005, p. 9). This area of the basin was shaped by Missoula Floods after the last ice age, leaving a coarse mix of fluvial deposits (Waitt, 1985). Although surface drainage comes from the buttes on the northern area of the Johnson Creek basin, distinct stream channels from these features generally do not extend to Johnson Creek. The topographic setting and the highly permeable deposits explains the minimal stream-channel development in this area of the Johnson Creek basin (Hogenson and Foxworthy, 1965, p. 11). 


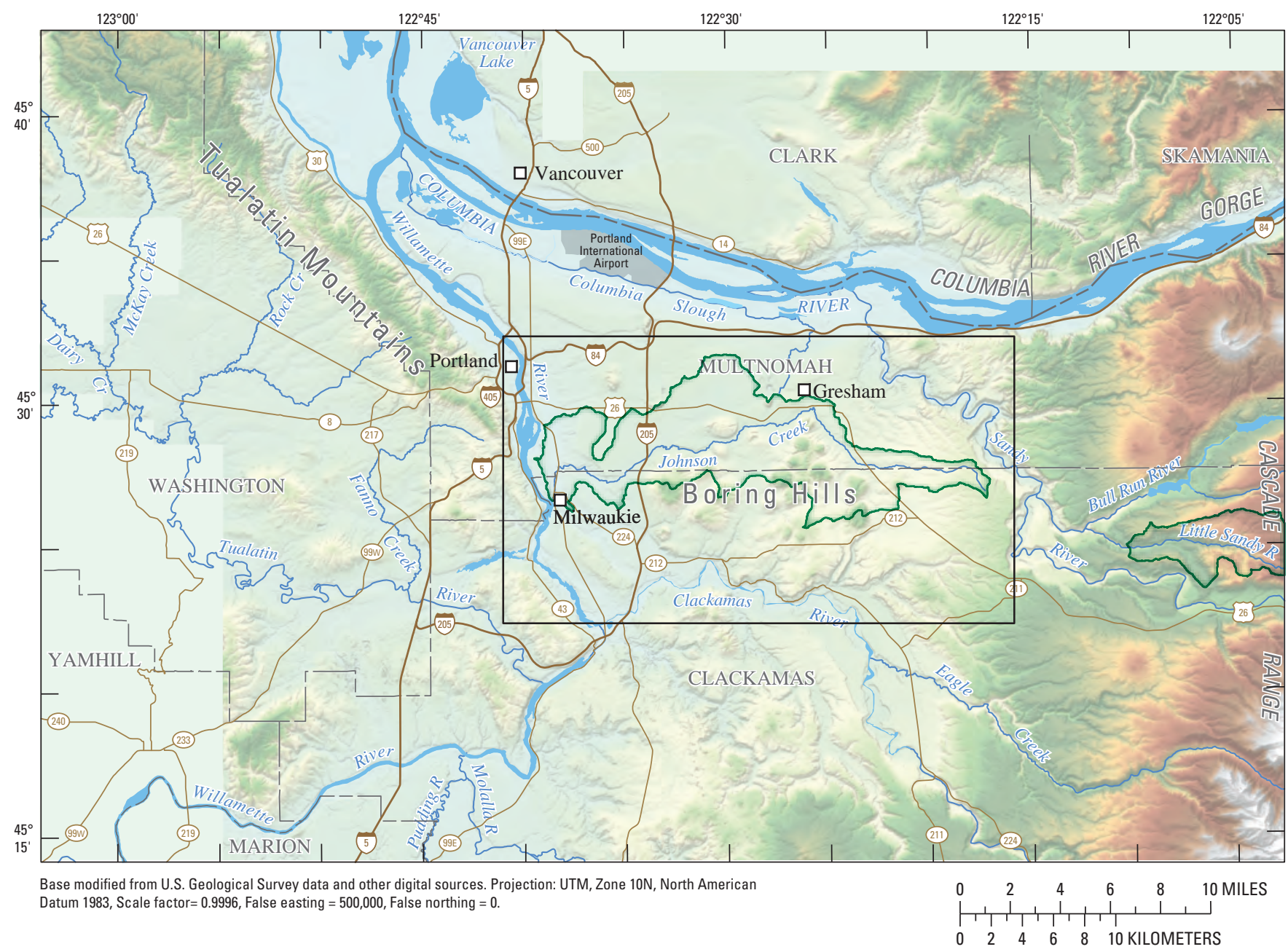

\section{EXPLANATION}

\section{$L$ and-surface elevation, in feet above}

North American Vertical Datum of 1988
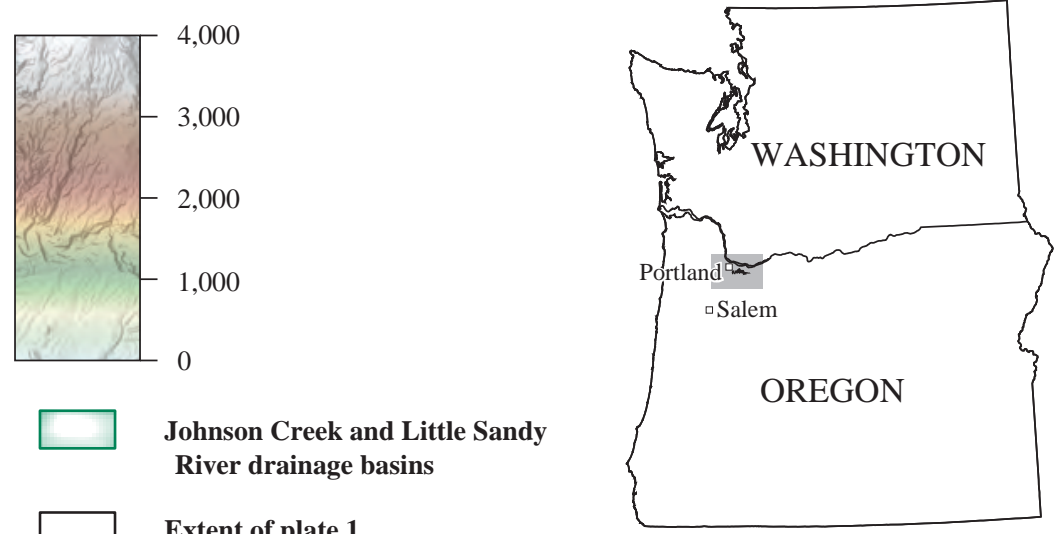

Extent of plate 1

Figure 1. Location of the Johnson Creek basin, Oregon. 
Except for Crystal Springs Creek and other spring inflows in the lower area of the Johnson Creek basin, no known perennial tributaries enter Johnson Creek from the north. Soils in the area are Multnomah and Latourelle loams, and some soils in areas near the creek midbasin are Wapato silt loam. In the lower area of the basin, Johnson Creek cuts through the terrace deposits as it flows toward the Willamette River. Near the confluence with Crystal Springs Creek, Johnson Creek enters an area of a former alluvial channel of the Clackamas River, the Willamette River, or both (Hogenson and Foxworthy, 1965, p. 10-11, 28). The creek turns south in the lower $1 \mathrm{mi}$ because of a bedrock outcrop near the confluence with the Willamette River.

Precipitation over the basin follows several pathways to groundwater and surface-water systems. In the eastern basin, delivery of stormwater to Johnson Creek is expedited by drains in agricultural areas, runoff from roads, ditches, and other hard surfaces, resulting in a rapid rise in response to precipitation. In the lower basin, some runoff is directed to the subsurface through drywells and to the sewer system that discharges outside the basin, resulting in lessened contribution to peak flows from the urban area. Summer flows of Johnson Creek are low through much of the basin because of low precipitation and, in places, minimal groundwater discharge. In some areas, regional groundwater flow paths lead away from Johnson Creek and toward nearby large rivers. In the lower basin, summer flow of Johnson Creek is sustained by groundwater discharge.

About three-fourths of the annual flow of Johnson Creek is from November through March, and less than 10 percent of the annual flow is in July through September. High-flow events typically begin with intense rainfall over 1 to 2 days during which prestorm conditions may include saturated soils, snow, or both.

\section{Land Use}

Land use varies in the Johnson Creek basin, and generally follows a gradient from forested, agricultural, and ruralresidential areas in the headwaters to urban and industrial areas in the lower basin. Land uses on the southern side of the basin include forest, nurseries, and light to dense residential. The northern side of the basin within the cities of Gresham and Portland is densely populated. Tanner and Lee (2004, p. 4, 6-7) discuss general land-cover categories for areas upstream of several monitoring sites on Johnson Creek.

The Johnson Creek basin, parts of which are in urban, suburban, and agricultural settings, has been affected by human occupation. Channel simplification, installation of storm drains, and paving over surfaces have affected the hydrologic character of the stream. In recent years, development has resulted in conversion of agricultural and light-residential areas to densely urban land uses, particularly in the southern and eastern areas of the Johnson Creek basin.
The stream channel of the lower $11 \mathrm{mi}$ of Johnson Creek was altered in a project of the Works Progress Administration in the 1930s. The primary purpose was flood control, and consisted of limiting the stream to a single, trapezoidal, masonry lined channel. Data collection in the basin did not begin until after the completion of this project. Although a systematic analysis of land use changes through time is beyond the scope of this report, the general grid of streets, drains, and ditches probably already was established by the 1940s.

Management of storm runoff in the basin varies considerably. As such, the fate of precipitation and subsequent runoff and/or groundwater recharge can differ, even within the same land-use category. For example, some agricultural areas are drained by a network of ditches and subsurface tile drains that facilitate rapid delivery of precipitation to the stream, whereas runoff from other areas may be managed by onsite infiltration through swales and ponds. Likewise, in urban areas, runoff can be routed out of the basin entirely through a combined sewer system (where sanitary sewage and stormwater runoff are combined in a single pipe), directed to the stream through storm-drain networks, or directed to onsite stormwater drainage systems that are designed to allow for the infiltration of stormwater. Stormwater drainage systems designed to divert stormwater runoff into the subsurface include underground injection control (UIC) systems (for example, stormwater injection systems, sumps, and drywells) and vegetated swales, pervious pavement, disconnected downspouts, and other diversion methods that are designed to allow for the infiltration of stormwater.

\section{Previous Investigations}

Previous investigations by the USGS in the Johnson Creek basin fall in three general categories: groundwater and geologic studies, surface-water studies including hydraulic and hydrologic modeling, and water-quality investigations. Although some results of these studies do not relate directly to the analyses in this report, most results contain relevant observations on the hydrology of the basin. For example, chemical characteristics reported in a water-quality study may offer new relevance in understanding the chemical signature of groundwater discharge to the stream.

Previous groundwater studies focused on the Portland basin, in which the Johnson Creek basin is located, and were the foundation for a regional groundwater flow model developed to identify the groundwater flow system and to provide a tool for groundwater managers to use in evaluating development scenarios. These studies and others are listed in Snyder (2008, p. 6, 33-37), a study estimating water-table elevation and unsaturated zone thickness throughout much of the Portland metropolitan area, including the Johnson Creek basin. 
Johnson Creek has been included in several surface-water studies, ranging in scope from the Portland metropolitan area to statewide. Laenen (1980) provided equations to estimate peak flow based on basin characteristics of the Portland urban area. Moffatt and others (1990) and Wellman and others (1993) provided statistical summaries of daily and peak streamflow data for streams throughout Oregon. Lee (1995) used dye-tracer methods to determine time of travel and dispersion characteristics of Willamette basin streams. Laenen and Risley (1997) constructed precipitation-runoff and streamflow-routing models of streams in the Willamette basin, and Lee and Risley (2002) estimated base flow of streams in the Willamette basin.

Water-quality studies include analyses and interpretation of whole-water, filtered, and bed sediment data. Edwards (1992), Edwards and Curtiss (1993), and Edwards (1994) provided analyses and interpretation, specific to the Johnson Creek basin, of physical characteristics (pH, dissolved oxygen, alkalinity, and specific conductance), nutrient, trace element, manmade organic compound, and sediment data during high- and low-flow periods. Johnson Creek was sampled in a Willamette River basin study for trace elements, organic compounds, and suspended sediment (Anderson and others, 1996). McCarthy and Gale (1999) used semipermeable membrane devices to assess the distribution of organic compound in a Columbia basin study. Finally, Tanner and Lee (2004) reported on organochlorine pesticides in whole-water samples from several locations on Johnson and Kelley Creeks, including changes in the relation of suspended sediment to pesticides over time.

\section{Purpose and Scope}

This report provides a quantitative description of the groundwater and surface-water hydrology of the Johnson Creek basin, including information about the interaction of the groundwater and surface-water systems, groundwater discharge to springs, surface manifestations of the water table, and groundwater influence on streamflow and stream temperature. This report also includes findings on spatial and temporal trends in annual, low, and high streamflow.

The results build upon previous investigations and longterm data. The previous investigations consist of a USGS regional groundwater study on the Portland metropolitan area and hydrologic and statistical studies of streamflow of Johnson Creek. The description of the groundwater system in this report is more general in nature. Conclusions of these investigations were derived from hydrogeologic mapping, well tests, groundwater level data, streamflow, and water-quality data. New data included measurements of groundwater level, streamflow, specific conductance, and stream temperature. Historic groundwater, streamflow, and climate data provided decade-scale context to the dynamics of the hydrologic system. New data collection and analyses provided explanation of specific hydrologic phenomena, particularly related to the interactions of the groundwater and surface water systems.

\section{Methods}

Hydrologic analyses in the Johnson Creek basin were based on data collected at numerous sites. Each groundwater and streamflow site has a unique 8 or 15 digit number and is associated with a map number that is used throughout the report (table 1; pl. 1). Map numbers 1 through 24 are groundwater sites and map numbers 25 through 45 are surface-water sites. Climate site numbers are assigned by the National Weather Service (NWS).

\section{Groundwater}

Groundwater level data were collected and evaluated using a monitoring well network consisting of wells measured quarterly or more frequently and supplemented by data from wells that were equipped with continuous groundwater level recorders for this study. Candidate wells were identified from previous USGS studies and from the Oregon Water Resources Department (OWRD) well database (http://www. oregon.gov/OWRD/PUBS/ToolsData.shtml). A criterion for selection was that the water level in a well should represent unconfined or water-table conditions. Priority was given to relatively shallow, recently constructed wells that had complete location information. Well information, including location, construction, and groundwater level measurements, was entered into the U.S. Geological Survey National Water Information System (NWIS), and is available online at http:// waterdata.usgs.gov/or/nwis/gw using the USGS site number (pl. 1; table 1). Groundwater levels relative to a measuring point on a well and the elevation of the groundwater relative to land surface were established using NGVD 1929 as the landsurface datum. The land-surface elevation at each well was determined from a topographic map or from a digital elevation model (DEM). The 2-m lateral resolution DEM covering most of the Portland metropolitan area was obtained from Metro (2002), the regional government agency serving the Portland metropolitan area. The vertical resolution of the 2-m DEM is reported as about $0.3 \mathrm{ft}$ (Metro, 2002). The land-surface elevations for wells used in the study were estimated using the 2-m DEM and calculated as the median land-surface elevation within a 100-ft radius of the reported locations. The buffer was used because most locations of wells and springs only are known to an accuracy of $100 \mathrm{ft}$, depending on the method of determination. The elevation of some wells additionally was determined by leveling from a known point, using methods established by Kennedy (1990). 
Table 1. Groundwater and surface-water sites in the Johnson Creek basin, Oregon.

[M ap No.: refers to the number on plate 1. USG S site No.: a unique 8 or 15 digit identification number. Additional information on groundwater and surfacewater sites are available from the USGS National Water Information System (NWIS) online at http://waterdata.usgs.gov/or/nwis using the USGS site number. OW R D well No.: Oregon Water Resources Department well number. Well reports (logs) documenting the well installation with information describing the well location, type of subsurface materials encountered, well depth, construction, and the depth to water are available online at http://www.wrd.state.or.us using the OWRD well number. Site name and location: All sites in Portland, Oregon, except as noted (name and approximate location). UTM E asting: The $\mathrm{X}$-coordinate used to identify the position of a feature based on the distance, in meters, east or west from the central meridian of the UTM zone (UTM zone 10; NAD 1927). UTM Northing: The Y-coordinate used to identify the position of a feature based on the distance, in meters, north of the equator (NAD 1927). L and-surface elevation: The elevation of the land-surface in feet above NGVD (1929) as determined from a digital elevation model (d) or from a topographic map (m). Elevation may differ from previously published values due to new method of determination. O pen interval: In a well, the screened part through which water enters. If open interval not known, used depth of well (e). Data type (a): PL, periodic water-level measurement; CL, continuous groundwater level recorder; PQ, periodic streamflow measurement; CQ, continuous stream level and streamflow recorder; CT, continuous stream temperature recorder; RT, realtime telemetry. A bbreviations: UTM, Universal Transverse Mercator; ft, foot; m, meter; -, not available]

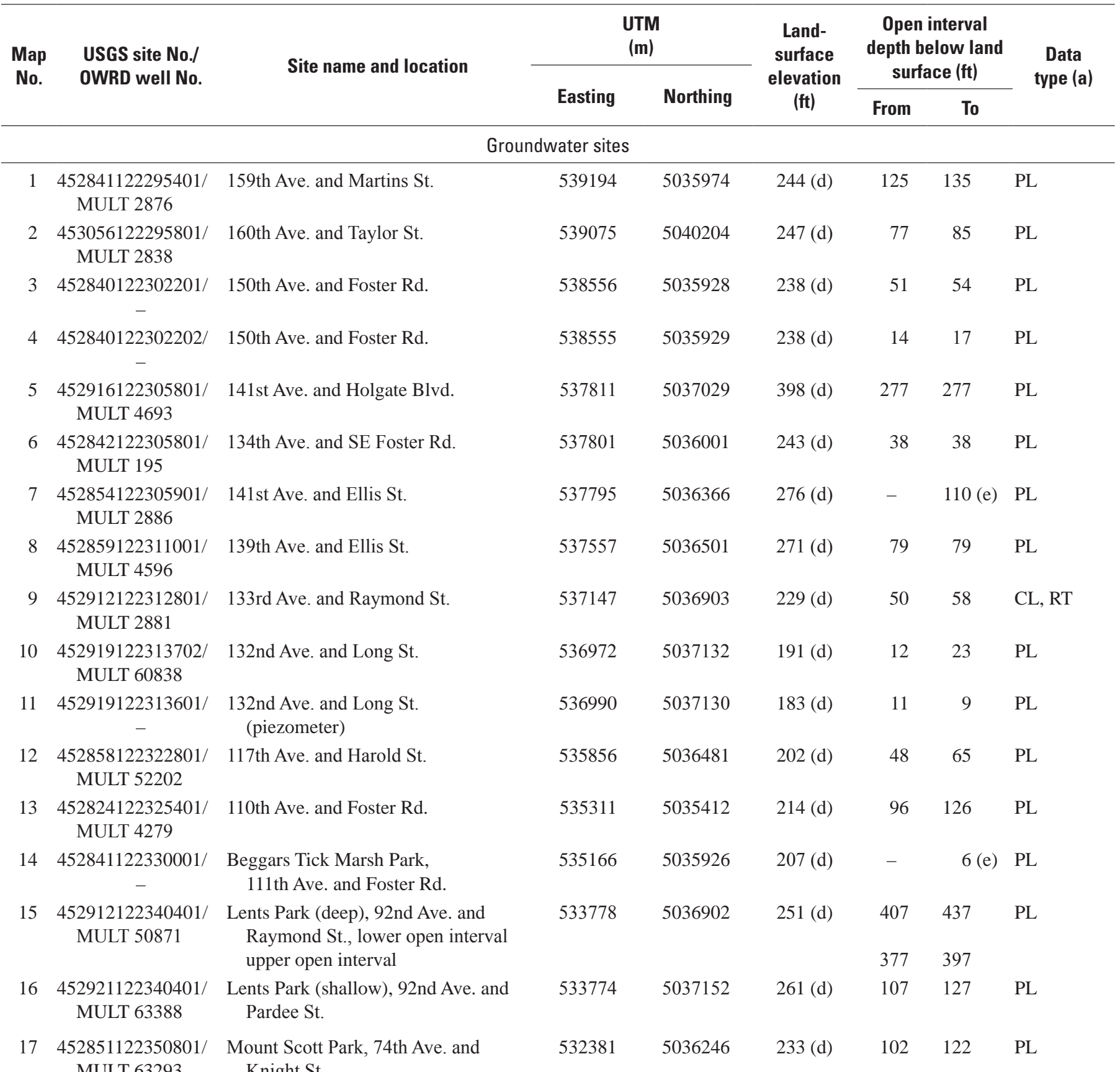


Table 1. Groundwater and surface-water sites in the Johnson Creek basin, Oregon.-Continued

\begin{tabular}{|c|c|c|c|c|c|c|c|c|}
\hline \multirow{3}{*}{$\begin{array}{l}\text { Map } \\
\text { No. }\end{array}$} & \multirow{3}{*}{$\begin{array}{l}\text { USGS site No./ } \\
\text { OWRD well No. }\end{array}$} & \multirow{3}{*}{ Site name and location } & \multicolumn{2}{|c|}{$\begin{array}{l}\text { UTM } \\
\text { (m) }\end{array}$} & \multirow{3}{*}{$\begin{array}{l}\text { Land- } \\
\text { surface } \\
\text { elevation } \\
\text { (ft) }\end{array}$} & \multirow{2}{*}{\multicolumn{2}{|c|}{$\begin{array}{c}\text { Open interval } \\
\text { depth below land } \\
\text { surface (ft) }\end{array}$}} & \multirow{3}{*}{$\begin{array}{l}\text { Data } \\
\text { type (a) }\end{array}$} \\
\hline & & & \multirow{2}{*}{ Easting } & \multirow{2}{*}{ Northing } & & & & \\
\hline & & & & & & From & To & \\
\hline \multicolumn{9}{|c|}{ Groundwater sites-Continued } \\
\hline 18 & $\begin{array}{l}\text { 452725122354301/ } \\
\text { CLAC } 347\end{array}$ & $\begin{array}{l}\text { 64th Ave. and Johnson Creek Blvd., } \\
\text { Milwaukie }\end{array}$ & 531607 & 5033575 & 149 (d) & 130 & 143 & PL \\
\hline 19 & $\begin{array}{l}\text { 452825122355501/ } \\
\text { MULT 63294 }\end{array}$ & $\begin{array}{l}\text { Brentwood Park, 62nd Ave. and } \\
\text { Cooper St. }\end{array}$ & 531376 & 5035423 & 255 (d) & 134 & 154 & CL \\
\hline 20 & $\begin{array}{l}\text { 452859122364701/ } \\
\text { MULT } 63237\end{array}$ & $\begin{array}{l}\text { Woodstock Park, 47th Ave. and } \\
\text { Harold St. }\end{array}$ & 530244 & 5036480 & 238 (d) & 147 & 167 & CL \\
\hline 21 & $\begin{array}{l}\text { 452822122372001/ } \\
\text { MULT } 63234\end{array}$ & $\begin{array}{l}\text { Berkeley Park, 39th Ave. and } \\
\text { Bybee Blvd. }\end{array}$ & 529538 & 5035326 & 194 (d) & 102 & 122 & CL \\
\hline 22 & $\begin{array}{l}\text { 452909122375001/ } \\
\text { MULT } 2784\end{array}$ & 32nd Ave. and Steele St. & 528867 & 5036780 & 137 (d) & 77 & 77 & PL \\
\hline 23 & $\begin{array}{l}\text { 452827122382401/ } \\
\text { MULT } 63238\end{array}$ & $\begin{array}{l}\text { Westmoreland Park (shallow), } \\
\text { 23rd Ave. and Bybee Blvd. }\end{array}$ & 528141 & 5035465 & $52(\mathrm{~d})$ & 20 & 25 & CL \\
\hline 24 & $\begin{array}{l}\text { 452827122382402/ } \\
\text { MULT } 63239\end{array}$ & $\begin{array}{l}\text { Westmoreland Park (deep), } \\
\text { 23rd Ave. and Bybee Blvd. }\end{array}$ & 528139 & 5035462 & $52(\mathrm{~d})$ & 76 & 96 & CL \\
\hline \multicolumn{9}{|c|}{ Surface-water sites } \\
\hline 25 & 452823122240900 & $\begin{array}{l}\text { Johnson Creek at Palmblad Rd. } \\
\text { near Gresham }\end{array}$ & 546724 & 5035448 & $360(\mathrm{~m})$ & - & - & PQ \\
\hline 26 & 14211400 & $\begin{array}{l}\text { Johnson Creek at Regner Rd. } \\
\text { at Gresham }\end{array}$ & 545282 & 5036930 & $305(\mathrm{~m})$ & - & - & CQ, CT, RT \\
\hline 27 & 452944122260000 & $\begin{array}{l}\text { Johnson Creek at Walters Rd. } \\
\text { at Gresham }\end{array}$ & 544276 & 5037910 & $290(\mathrm{~m})$ & - & - & PQ \\
\hline 28 & 452917122275700 & $\begin{array}{l}\text { Johnson Creek at 190th Ave. } \\
\text { at Gresham }\end{array}$ & 541707 & 5037098 & $260(\mathrm{~m})$ & - & - & PQ \\
\hline 29 & 14211499 & Kelley Creek at 159th Dr. & 539321 & 5035863 & $245(\mathrm{~m})$ & - & - & CQ, CT, RT \\
\hline 30 & 14211500 & Johnson Creek at Sycamore & 538559 & 5035928 & $228(\mathrm{~m})$ & - & - & CQ, CT, RT \\
\hline 31 & 452835122324200 & Johnson Creek at Brookside Park & 535585 & 5035749 & $220(\mathrm{~m})$ & - & - & $\mathrm{PQ}$ \\
\hline 32 & 452747122344000 & Johnson Creek at 82nd Ave. & 533012 & 5034327 & $190(\mathrm{~m})$ & - & - & $\mathrm{PQ}$ \\
\hline 33 & 452743122365400 & Johnson Creek at 45th Ave. & 530068 & 5034124 & $80(\mathrm{~m})$ & - & - & PQ \\
\hline 34 & 452749122370000 & Errol Spring Creek at mouth & 529965 & 5034331 & $80(\mathrm{~m})$ & - & - & $\mathrm{PQ}$ \\
\hline 35 & 452750122365300 & $\begin{array}{l}\text { Storm Drain adjacent to Errol } \\
\text { Spring Creek }\end{array}$ & 529963 & 5034356 & $80(\mathrm{~m})$ & - & - & PQ \\
\hline 36 & 452754122374800 & Johnson Creek at Berkeley Pl. & 528990 & 5034455 & $70(\mathrm{~m})$ & - & - & PQ \\
\hline 37 & 452740122382700 & Johnson Creek at Sherrett St. & 528104 & 5034023 & $40(\mathrm{~m})$ & - & - & PQ \\
\hline 38 & 452856122380000 & $\begin{array}{l}\text { Crystal Springs Creek at } \\
\text { Reed College }\end{array}$ & 528656 & 5036369 & $70(\mathrm{~m})$ & - & - & PQ \\
\hline 39 & 14211542 & $\begin{array}{l}\text { Crystal Springs Creek at Bybee } \\
\text { Blvd. }\end{array}$ & 528074 & 5035472 & $50(\mathrm{~m})$ & - & - & CT, PQ \\
\hline 40 & 14211546 & Crystal Springs Creek at mouth & 528016 & 5033990 & $40(\mathrm{~m})$ & - & - & CT, PQ \\
\hline 41 & 14211550 & Johnson Creek at Milwaukie & 527998 & 5033126 & $30(\mathrm{~m})$ & - & - & CQ, CT, RT \\
\hline 42 & 14211559 & $\begin{array}{l}\text { Johnson Creek at mouth } \\
\text { at Milwaukie }\end{array}$ & 527966 & 5032226 & $20(\mathrm{~m})$ & - & - & PQ \\
\hline 43 & 452919122313701 & Holgate Lake & 537000 & 5037130 & 190 (d) & - & - & CL, PL \\
\hline 44 & 14211720 & Willamette River & 526050 & 5040330 & $2(\mathrm{~m})$ & - & - & CQ, RT \\
\hline 45 & 14141500 & Little Sandy River near Bull Run & 564920 & 5029220 & $720(\mathrm{~m})$ & - & - & CQ, RT \\
\hline
\end{tabular}




\section{Surface Water}

Surface-water data consist of records from continuous streamflow sites and individual streamflow measurements (pl. 1; table 1). The continuous streamflow sites are: Johnson Creek at Regner Road, at Gresham (map number 26), beginning in 1998; Johnson Creek at Sycamore (map number 30), beginning in 1940; Johnson Creek at Milwaukie (map number 41), beginning in 1989; and Kelley Creek at 159th Drive at Portland (map number 29) beginning in 2000. Streamflow records were computed according to methods described in Rantz and others (1982). Daily mean streamflow and instantaneous peaks are from the U.S. Geological Survey National Water Information System (NWIS), and are available online at http://waterdata.usgs.gov/or/nwis/sw by using the USGS site number to access the information (table 1).

Several streamflow statistics based on aggregated daily mean streamflow values were used to characterize mean and low-flow conditions. Thus, daily mean streamflow was averaged over an annual time scale to provide an indication of annual mean flow conditions. Low streamflow was characterized using the annual 7-day and 30-day minimum streamflow, which is the average of the lowest 7 or 30 consecutive daily mean streamflow values during a specified time period during each year, respectively. For example, the annual 7-day low flow during the months of May through October for each year of streamflow record would be calculated as the average streamflow of the lowest 7 consecutive daily mean streamflows during the months of May through October only. Base-flow separation, using the program PART, partitions daily mean streamflow to estimate the base-flow component (Rutledge, 1998). Flowduration curves, which were developed by ranking daily mean streamflow over a given time period and calculating the percentage of time that a specified daily mean streamflow was equaled or exceeded (Searcy, 1959), also were used to characterize low streamflow.

High flows were characterized for streamflow sites with more than 10 years of record using annual peak streamflow data. Peak streamflow frequency, commonly termed flood frequency, indicates the annual exceedance probability associated with a particular magnitude of annual peak streamflow. For example, an annual peak streamflow with a 1-percent exceedance probability represents a large flood that has only a 1-percent chance of that streamflow being exceeded in any year. The reciprocal of the annual exceedance probability is the average recurrence interval of a particular annual peak streamflow. Thus, the flood with an annual exceedance probability of 1 percent has an average recurrence interval of 100 years and commonly is referred to as the 100-year flood. Flood frequency data for this study were determined by fitting the log Pearson 3 probability distribution to the recorded annual peak streamflow values at each site having sufficient record using methods described by the U.S. Interagency Advisory Committee on Water Data (1982) and Flynn and others (2006).
Streamflow measurements were used to determine temporal changes in groundwater discharge to springs and to identify gains or losses in streamflow from the stream as a result of interaction with the groundwater system using methods described in Rantz and others (1982). Streamflow measurements were made at many locations on Johnson Creek and tributary streams. Streamflow measurements at all locations described in this report are available online from the U.S. Geological Survey National Water Information System (NWIS), and are available at http://nwis.waterdata.usgs.gov/ or/nwis/measurements by using the USGS site number. Spring discharge was determined by measuring the streamflow in the channel formed by the spring. Because springs in the Johnson Creek basin typically emerge at multiple locations, the streamflow was measured downstream where depth and uniformity of flow were sufficient for measurement by a current meter. Streamflow generally was measured during dry-weather periods to most accurately characterize spring discharge.

Seepage measurements are an indirect method of quantifying groundwater discharge (gains) or recharge (losses) at the streambed. Seepage measurements consist of a series of streamflow measurements made at numerous locations along a stream reach at nearly the same time. Assuming no tributary inflows or streamflow diversions from one location to the next, the difference in streamflow at the two locations indicates the net gain or loss attributed to interaction with the groundwater system. As such, a seepage study is a "snapshot" at a given time of the interaction of the stream and the surrounding aquifer. Seepage measurements are made during the summer low-flow period when streamflow is fairly constant and runoff from precipitation is minimal.

As a result of streamflow measurement uncertainty, the use of seepage measurements to determine streamflow gains and losses may not be reliable when the gains or losses are a relatively small percentage of the measured streamflow. The accuracy of a streamflow measurement is determined by several factors, including uniformity of velocity, channel characteristics, and limitations of the meter in use. Most streamflow measurements made during this study were rated as "good," meaning they were within 5 percent of the actual value. The determination of gains and losses and the effect of measurement uncertainty are described in Lee and Risley, (2002, p. 22-23).

Spatial and temporal variations in hydrologic data were analyzed by using parametric and nonparametric methods. Spatial variations generally were analyzed using linear regression, a parametric method that relates one hydrologic variable to another with a best-fit line (equation). The strength of the linear regression relation commonly is measured by the R-squared $\left(\mathrm{R}^{2}\right)$ value. Correlation was used to quantify the degree by which two variables are related. The strength of the correlation is described by the $R$ value. A nonparametric correlation method, Kendall's tau, was used to analyze temporal variations or temporal trends of hydrologic 
variables (Helsel and Hirsch, 2002). Kendall's tau is the correlation between the ranked values of two variables, and was implemented using the S-PLUS ${ }^{\circledR}$ data-analysis software (Insightful Corporation, 2005). Values of Kendall's tau range from -1 to +1 . The sign of Kendall's tau indicates whether the relation is directly proportional (positive value) or inversely proportional (negative value). The magnitude of the deviation (either positive or negative), from zero indicates the strength of trend. The null hypothesis is that no temporal trend exists. The statistical significance of the trend was evaluated by the probability ( $p$ ) that the observed trend happened by chance. A p-value of 0.05 indicates a 95-percent probability that the observed trend is not a chance occurrence. For this study, Kendall's tau values having $p$-values less than 0.05 were considered significant.

\section{Water Quality}

Water-quality results consist of discrete stream samples analyzed for specific conductance and data from continuous stream-temperature recorders. Temperature data were recorded at long-term streamflow sites and at other locations for several weeks in conjunction with seepage studies. Continuous stream-temperature data collection in the Johnson Creek basin began in 1998 (pl. 1; table 1). Daily maximum, minimum, and mean stream temperature data are stored in the NWIS, and are available online at http://waterdata.usgs. gov/or/nwis/qw by using the USGS site number to access the information. Summer stream temperature was characterized using the 7-day average maximum value, a statistic commonly used for regulatory purposes. Samples analyzed for specific conductance and short-term, continuous temperature data collected during the seepage studies were used as a qualitative measure of groundwater discharge to the stream. The shortterm temperature data collected in conjunction with the seepage studies are not published, but are available from the Oregon Water Science Center. Specific conductance (Wilde, 2005) and stream temperature data (Wagner and others, 2006) were collected according to set guidelines.

\section{Meteorologic Data}

The NWS site at the Portland Airport (site number 356751), about 10 mi north of the mouth of Johnson Creek, was the primary source of precipitation data. These data were provided by the NWS and served to the public by the Oregon Climate Service (Oregon Climate Service, 2007). Climate data at the Portland Airport began in 1938. These data were merged with unadjusted monthly total precipitation data at the NWS site in downtown Portland (site number 356761) from 1911 to 1937 (Oregon Climate Service, 2007). Some data gaps were filled with monthly precipitation data from Vancouver, Washington (site number 458773), about 10 mi northwest of the Portland Airport (National Oceanic and Atmospheric
Administration, 2007), and Salem, Oregon (site number 357500), about $50 \mathrm{mi}$ to the south (Oregon Climate Service, 2007). The precipitation data from Vancouver and Salem were adjusted proportionally, based on adjacent periods of concurrent data.

Precipitation data at the fixed location and the spatial distribution of precipitation were assessed using the Precipitation Elevation Regressions on Independent Slopes Model (PRISM) (PRISM Group, 2007). PRISM is a data layer of estimated annual precipitation in the State of Oregon in $800 \times 800 \mathrm{~m}$ grid cells based on the period from 1971 to 2000 .

\section{Groundwater Hydrology}

The elements of the groundwater hydrology of Johnson Creek basin include the basic inflow (recharge) and outflow (discharge), and the change in storage manifested by fluctuations in water levels. Understanding of these elements provides a foundation for discussion of the groundwaterrelated events that motivated this study: extremes in streamflow of Crystal Springs Creek, the emergence of the water table in a low-lying area of the basin (Holgate Lake (map number 43)), and spatial and temporal trends in groundwater discharge to Johnson Creek.

\section{Recharge}

Recharge to the Johnson Creek basin is through the infiltration of precipitation, although in areas of urban development, the diversion of stormwater runoff into UIC systems and infiltration of effluent from onsite waste-disposal (septic) systems are additional sources of recharge. Recharge to the Portland basin was estimated using data from the late 1980s by Snyder and others (1994, p. 30). Within the Johnson Creek basin recharge ranged from 0 to $48 \mathrm{in} / \mathrm{yr}$, with a mean of about $22 \mathrm{in} / \mathrm{yr}$. Recharge from UIC systems and septic systems contributed about 11 and 12 percent of the total, respectively. Irrigation-return flow and losing streams also may constitute locally important sources of seasonal recharge; however, they were not quantified by Snyder and others (1994, p. 3).

The addition of UIC systems and the removal of septic systems since the study by Snyder and others (1994) require a recalculation of recharge based on 2008 conditions using the methods of Snyder and others (1994). The addition of UIC systems increases recharge by routing stormwater runoff onsite to the subsurface, whereas stormwater runoff was previously routed out of the basin through a combined sewer system. Removal of septic systems decreases recharge by routing sewage to the sewer system that had previously been infiltrated onsite. For this study, it was assumed that the pattern of spatial distribution and rates of precipitation have not changed much since the study by Snyder and others (1994). Although impervious area is expected to increase 
because of infill development in the urban areas and new development in the rural areas, it was beyond the scope of this study to evaluate the effect of these changes on the amount of recharge from the infiltration of precipitation. Therefore, the infiltration of precipitation calculated by Snyder and others (1994) was considered to be representative of conditions for this study. The number of UIC systems has increased substantially and nearly all septic systems in the areas used in that analysis have been removed as part of an extensive sewer improvement project in central Multnomah County. Recharge from septic systems in rural areas of the Johnson Creek basin was not quantified by Snyder and others (1994, p. 26) or by this analysis because these areas generally are less densely populated than the rest of the basin. However, septic systems do remain in some unincorporated urbanized areas but they are the focus of efforts for decommissioning (Andrew Swanson, Clackamas County's Water Environment Services, written commun., 2008). The source of the water supply used for septic systems can be either internal or external to the Johnson Creek basin; however, for this study, no distinction was made regarding the source of water for septic systems. Recharge is possible from overbank floodwaters of Johnson Creek, particularly in the area just east of I-205. This recharge might affect groundwater levels and the quantity of discharge at locations in the study area and downgradient of the recharge area for short periods of time.

The analysis by Snyder and others (1994, p. 23) estimated there were about 3,700 UIC systems owned by public agencies in Multnomah County and an undetermined number of privately owned UIC systems. Estimates of the number of UIC systems in the Portland metropolitan area in 2008 include about 11,000 publicly owned and 25,000 to 35,000 privately owned UIC systems, most are in Multnomah County (Snyder, 2008, p. 6-7). The area drained by the newly installed, publicly owned UIC systems in the Johnson Creek basin is an additional 2,100 acres. These new UIC systems are estimated to contribute recharge at a rate of $10.6 \mathrm{in} / \mathrm{yr}$, the same mean rate of recharge for areas with UIC systems already identified within the Johnson Creek basin (Snyder and others, 1994, pl. 1B), for about 1,800 acre-ft/yr of additional recharge to the Johnson Creek basin. This additional recharge represents a 22-percent increase in recharge from UIC systems to the Johnson Creek basin since the analysis by Snyder and others (1994), which estimated recharge from UIC systems to be about 8,100 acre-ft.

The recharge from areas with septic systems within the Johnson Creek basin identified by Snyder and others (1994, pl. 1C) totaled about 7,400 acre-ft/yr. The installation of sanitary sewer systems in these areas has resulted in the decommissioning of nearly all these septic systems. For this calculation, the quantity of recharge previously attributed to septic systems has been diverted to the sewer systems and no longer contributes to recharge in the Johnson Creek basin.
The 2008 annual recharge for the Johnson Creek basin is equal to the recharge estimate of 66,600 acre-ft as reported by Snyder and others (1994), supplemented by 1,800 acre-ft of recharge from new UIC systems, and reduced by 7,400 acre-ft because of the decommissioning of septic systems resulting in an estimated annual recharge of 61,000 acre-ft for 2008 in the Johnson Creek basin. The change in recharge resulting from the 2008 configuration of UIC systems and septic systems by about 5,600 acre-ft/yr represents about an 8-percent reduction since the analysis by Snyder and others (1994) to the Johnson Creek basin. This change in recharge was almost entirely within the intervening drainage basin area between the Milwaukie and Sycamore sites. The recharge to the drainage basin area upstream of the Sycamore site is unchanged from the analysis of Snyder and others (1994) and was estimated at 34,500 acre-ft/yr. These estimates of recharge assume that the infiltration of precipitation is identical to that of the previous analysis by Snyder and others (1994) and does not take into consideration the substantial but unknown amount of recharge contributed from privately owned UIC systems or from the installation of new septic systems outside areas where sanitary sewers are available. These changes to recharge may result in changes in the discharge to rivers, streams, and springs or may be reflected in changes in groundwater levels.

\section{Groundwater Discharge}

Groundwater in the Johnson Creek basin discharges to springs, to the stream by leakage through the streambed, to wells, by evapotranspiration, and by subsurface flow to other basins. The existence of streamflow during the late summer, a period of little or no precipitation, indicates groundwater discharge. Groundwater withdrawals by wells are mostly restricted to the eastern area of the basin, where wells are used for domestic supply and for irrigation (Collins and Broad, 1993). Municipal sewage is not discharged to Johnson Creek. Evapotranspiration is not a major source of groundwater discharge because the depth to groundwater typically exceeds plant root depth. Evapotranspiration losses probably are greatest in areas of shallow groundwater adjacent to Johnson Creek and in wetland areas just east of I-205 at Beggars Tick Marsh (pl. 1).

Groundwater discharge, which contributes to flow of Crystal Springs and Johnson Creeks, was estimated in several ways: (1) using measurements of springs (and predominantly spring-fed streams) available since the 1970s, (2) using seepage measurements made along Johnson Creek from 1988 to 2006, (3) comparing streamflow in Johnson Creek at the streamflow sites during the low-flow period from 1989 to 2006, (4) comparing base-flow separation results for different time periods at the Johnson Creek streamflow sites, and (5) assessing qualitatively the groundwater discharge to Johnson Creek using environmental tracers (chemical and thermal characteristics of the stream). 


\section{Springs and Seepage}

Johnson Creek is a perennial stream, where flow is sustained during the dry summer and autumn by groundwater discharge. Groundwater discharge occurs as springs, where a distinct flow emanates from an area, typically as a small stream forming a tributary to Johnson Creek, or as seepage through the streambed. Seepage may be visible if it discharges along the banks above stream level. Relative to streamflow, springs and seepage studied in this report are groundwater contributions to the stream. Most spring and seepage discharge to Johnson Creek is downstream of RM 5.5. The predominance of springs and seepage in the lower basin results in relatively high summer flow compared to the flow upstream of RM 5.5.

Crystal Spring (fig. 1) is the largest spring in the Johnson Creek basin, and, as referred to in this report, consists of several complexes of springs that discharge to Crystal Springs Creek. The individual spring locations are described in McFarland and Morgan (1996, p. 8, p. 24-27) and in McCarthy and Anderson (1990, p. 31). Crystal Springs Creek is about $2.5 \mathrm{mi}$ long, flows westward from the Reed College campus, southward through a golf course, Westmoreland Park, and residential areas, entering Johnson Creek at RM 1.0. Crystal Springs Creek provides most of the summer streamflow of Johnson Creek downstream of RM 1.0. Spring flow originates in two general areas. The upper spring complex is on the Reed College campus, where flow emanates from the bluffs surrounding a lake and wetland area. The lower spring complex is about $1 \mathrm{mi}$ from the mouth of the creek, where flow emanates at several locations from the bluffs to the east, flowing into a constructed pond, and then into the main channel of Crystal Springs Creek.

An increase in the height of the water surface of Crystal Springs Creek, noted by local residents beginning in July 1997, prompted inquiry by the city of Portland (Chestnut, 1997). Streamflow measurements were made at three locations: (1) on the Reed College campus at RM 1.8 (map number 38), (2) at RM 1.0 (map number 39), and (3) at the mouth of the creek (map number 40) (pl. 1). The streamflow measurements characterized the peak in 1997, tracked a multiyear recession, and by 2001 the streamflow had receded to the rate observed a decade earlier (ㅎg. 2).

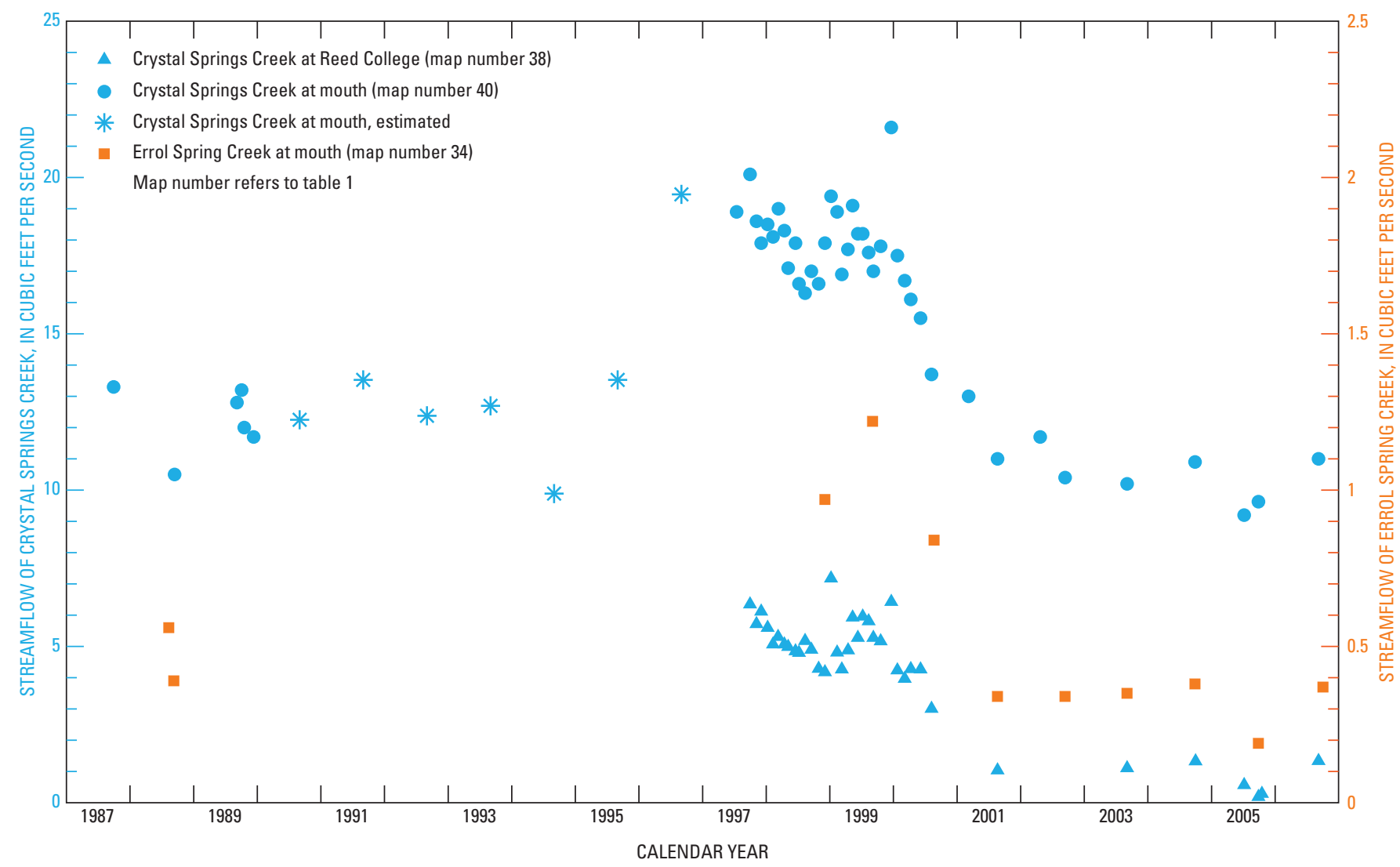

Figure 2. Streamflow measurements of Crystal Springs Creek at Reed College, measurements and estimates of streamflow at the mouth of Crystal Springs Creek, and measurements of Errol Spring Creek, Portland, Oregon. 
Measurements of streamflow of Crystal Springs Creek in the Reed College area began in 1988 when the combined discharge of several distinct springs was $1.6 \mathrm{ft}^{3} / \mathrm{s}$ (McFarland and Morgan, 1996, p. 26). In this study, discharge of the springs, determined by streamflow measurements of Crystal Springs Creek in the Reed College area, ranged from a maximum of $6.3 \mathrm{ft}^{3} / \mathrm{s}$ in September 1997 to a minimum of $0.16 \mathrm{ft}^{3} / \mathrm{s}$ in September 2005 (fig. 2). Two measurements in 1999 indicated greater streamflow; however, surface runoff or release of water from a beaver dam may have temporarily increased the flow of Crystal Springs Creek. Streamflow measurements made in 2001, 2003, and 2004 indicated that the flow was about $1 \mathrm{ft}^{3} / \mathrm{s}$. The low streamflow observed in 2005 was followed by an increase to $1.31 \mathrm{ft}^{3} / \mathrm{s}$ in 2006 .

Streamflow measurements made prior to 1997 (primarily during the summer and autumn) at or near the mouth of Crystal Springs Creek indicate that the collective discharge of the springs was between 10.5 and $14.8 \mathrm{ft}^{3} / \mathrm{s}$. Concurrent streamflow measurements in 1997 and 1998 at RM 1.0 and at the mouth of the creek indicate that the difference in streamflow usually is within the range of measurement uncertainty, so data from either site can be used for comparison. The earliest known streamflow of Crystal Springs Creek was $12.4 \mathrm{ft}^{3} / \mathrm{s}$ in 1872 , when the City of Portland was considering the feasibility of tapping Crystal Springs Creek as a source for public water supply (McFarland and Morgan, 1996, p. 26). The high streamflow of Crystal Springs Creek, as measured in 1997, seems to have begun the previous year. Although Crystal Springs Creek was not measured in 1996, streamflow was inferred from streamflow of Johnson Creek at Milwaukie (map number 41) by using the relation of late summer streamflow of Crystal Springs Creek to that of Johnson Creek at Milwaukie (fig. 3). The streamflow measurements of Crystal Springs Creek used for this analysis were made during the period from August to October 1989 and August to October of every year from 1997 to 2006. These streamflows were related to the annual 7-day minimum streamflow of Johnson Creek at Milwaukie for the same period. Based on this relation, the streamflow of Crystal Springs Creek in late summer 1996 was estimated to be 19.5 $\mathrm{ft}^{3} / \mathrm{s}$, close to that measured in July 1997.

The streamflow of Crystal Springs Creek at the mouth (map number 40) decreased from 1997 to 2001, decreased less rapidly from 2002 to 2005, and similar to the upper spring area, increased slightly in 2006 (fig. 2). The streamflow reached $20.1 \mathrm{ft}^{3} / \mathrm{s}$ in September 1997, which is about 60 percent greater than measured or estimated values between 1987 and 1995. Although the maximum streamflow is in December 1999, this high flow probably was a result of surface runoff or beaver activity. Streamflow in July 2005 was $9.2 \mathrm{ft}^{3} / \mathrm{s}$, lower than any previous measurement of Crystal Springs Creek.

Errol Spring, a complex of individual springs, emanates from a bluff about $0.3 \mathrm{mi}$ from Johnson Creek and forms what is known locally as Errol Spring Creek (map number 34) (pl. 1). Errol Spring Creek passes through a wetland and enters Johnson Creek at RM 3.1.

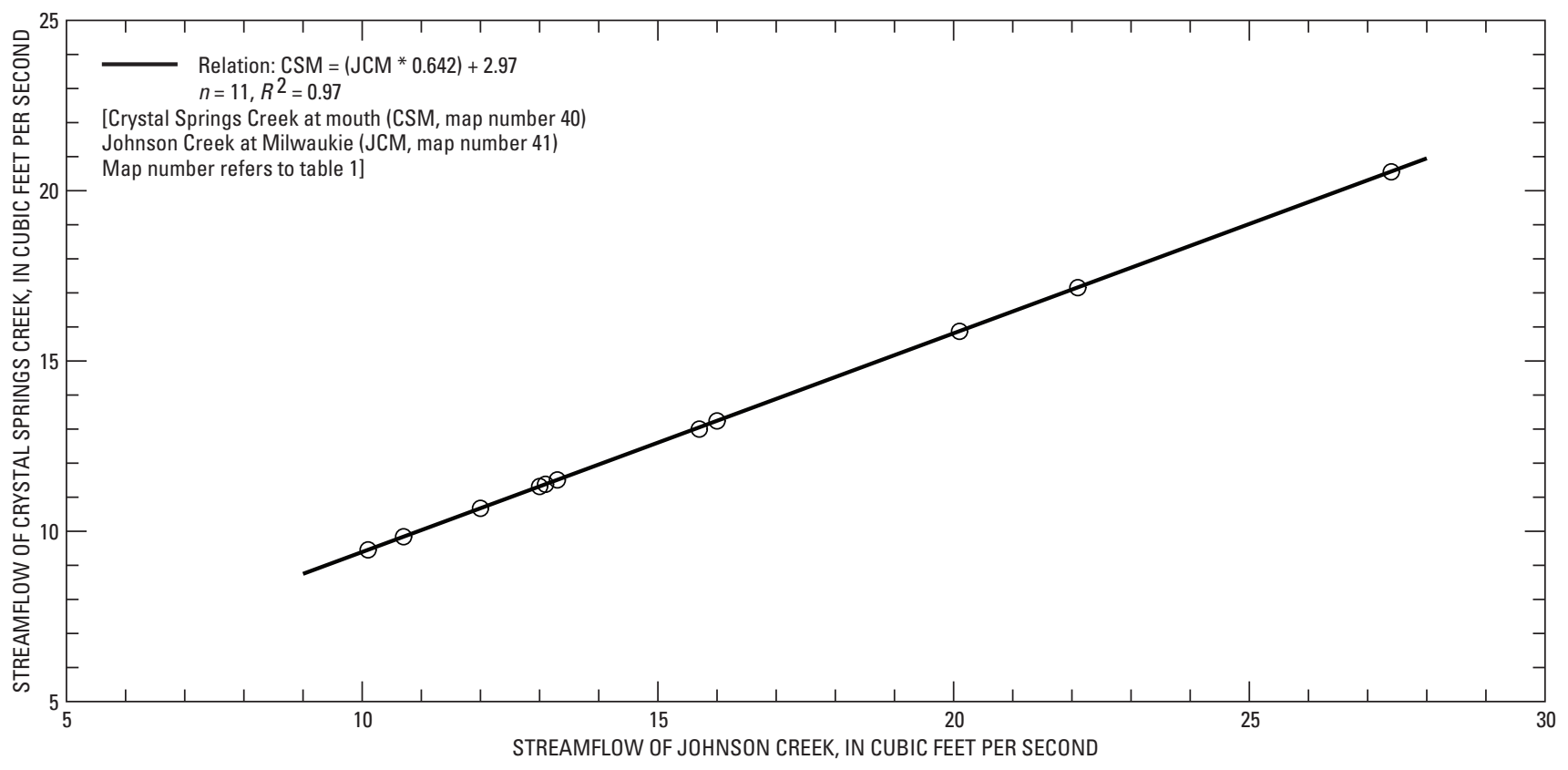

Figure 3. Relation between average measured streamflow at the mouth of Crystal Springs Creek, Portland, Oregon, and consecutive 7-day average low streamflow of Johnson Creek at Milwaukie, Oregon, August to October 1989, 1997-2006. 
Another spring discharges to Johnson Creek through a pipe (map number 35) a few feet downstream of the mouth of Errol Spring Creek. This spring emanates from the bluffs near Errol Spring and flows under industrial properties nearby, incorporating street drainage along its length, and is piped to Johnson Creek. Measurements of this spring were made in late summer of 1988, 1999, 2000, and 2006, and indicated fairly similar discharge to Errol Spring Creek.

Errol Spring Creek was measured in August and September 1988 when the streamflow was 0.56 and $0.39 \mathrm{ft}^{3} / \mathrm{s}$, respectively (ig. 2). Errol Spring Creek was first measured for this study in 1998 when the streamflow was $0.97 \mathrm{ft}^{3} / \mathrm{s}$, or about twice the streamflow measured a decade before. Streamflow of Errol Spring Creek remained relatively high in 1999 and 2000. Measurements from 2001 to 2004 indicated a steep decrease compared to streamflow observed in 1998 to 2000. Flow decreased to $0.19 \mathrm{ft}^{3} / \mathrm{s}$ in 2005 and increased to $0.37 \mathrm{ft}^{3} / \mathrm{s}$ in 2006. The general pattern of fluctuation in streamflow of Errol Spring Creek from 1988 to 2006 was similar to that of Crystal Springs Creek.

Numerous springs emanate from bluffs along the southern side of Johnson Creek between RM 3.2 (map number 33) and RM 2.2 (map number 36). These springs have not been measured directly by the USGS; however, streamflow measurements made on Johnson Creek at RM 3.2 and 2.2 in 1988, 1998, 1999, 2000, and 2006 indicate groundwater inflows (including Errol Spring) of between 0.73 and $2.40 \mathrm{ft}^{3} / \mathrm{s}$ (table 2).

Several springs discharge near the mouth of Johnson Creek in Milwaukie. Spring Creek enters Johnson Creek at RM 0.4. The streamflow of Spring Creek was $1.2 \mathrm{ft}^{3} / \mathrm{s}$ in 1988 (McFarland and Morgan, 1996, p. 57). Another spring once used to fill a public swimming pool in downtown Milwaukie is piped to Johnson Creek at RM 0.1. Collectively, the discharge of springs to Johnson Creek between the Milwaukie streamflow site (map number 41) and the mouth of the creek (map number 42) was $4.3 \mathrm{ft}^{3} / \mathrm{s}$ in 1988 and $4.1 \mathrm{ft}^{3} / \mathrm{s}$ in 2006.

Comparison of the decrease in flow of springs in the high-flow years of 1996-99 to the low flows of 2005 indicates that streamflow of Crystal Springs Creek in the Reed College area and Errol Spring Creek decreased much more rapidly than Crystal Springs Creek at the mouth. By 2005, the flow of Crystal Springs Creek in the Reed College area was about 3 percent of the peak streamflow, and Errol Spring Creek decreased to about 20 percent of that observed in 1998. Streamflow of Crystal Springs Creek at the mouth decreased to 50 percent of the peak, indicating that the saturated thickness of the groundwater contributing area to the upper Crystal Springs and Errol Spring Creeks is much less than that of the lower Crystal Springs Creek because of the higher topographic position of the upper Crystal Springs and Errol Spring Creeks. Therefore, changes in the water-table elevation have a proportionately larger effect on groundwater discharge to upper Crystal Springs Creek and Errol Spring Creek relative to the groundwater discharge contributing to lower Crystal Springs Creek. The springs contributing streamflow to the lower area of Crystal Springs Creek additionally may be the result of regional groundwater flow, which may be less sensitive to short-term climatic variation.

Seepage is the exchange between groundwater and surface water at the streambed forming the boundary between a stream and an aquifer system. Rates and locations of seepage to and from Johnson Creek were determined by evaluating the difference (gain or loss) in measured streamflow between measurement locations. Although some recharge to the system is from losing reaches of Johnson Creek, most of reaches are gaining, receiving discharge from the groundwater system. Seepage measurements were made each summer from 1997 through 2000 and in 2006 as part of this study and compared to seepage measurements made in 1988 (fig. 4, table 2).

Precipitation in water years when seepage measurements were made varied widely (fig. 5). Although the average (WY 1911-2006) precipitation at the Portland Airport is about 37 in., precipitation was several inches less than average in WY 1988 and 2000, and several inches more than average in WY 1998, 1999, and 2006 (Oregon Climate Service, 2007). Precipitation in WY 1997 was the highest since recordkeeping began in 1911, and was about $21 \mathrm{in.} \mathrm{more} \mathrm{than} \mathrm{average.}$

The individual measurements and general conditions for quantifying gains and losses to the stream were good overall; however, the measurements for the 2006 study caused considerable uncertainty because of multiple beaver dams between RM 17.2 and 1.2. The inability to measure the streamflow at several of the sites measured previously because of ponded conditions and the buildup and subsequent wash-out of these dams raised uncertainty about the stability of flows during the 2006 study.

The Johnson Creek basin was divided into three reaches for this analysis based on seepage characteristics. The upper reach extends from RM 17.2 to 10.2 (pl. 1). The slope of the stream in the upper reach is $20 \mathrm{ft} / \mathrm{mi}$ and the elevation of the channel decreases from 370 to $228 \mathrm{ft}$. The drainage basin area increases by $14.3 \mathrm{mi}^{2}$ in this reach (Tanner and Lee, 2004, p. 7). Much of the surface-water contributing area (the area in a drainage basin that contributes water to streamflow) of this reach consists of Troutdale Formation gravels and steeply sloped volcanic buttes. These materials are less permeable than the deposits north and west of this reach. The middle reach is from RM 10.2 to 5.5 (pl. 1). The slope of the stream channel in the middle reach is $8 \mathrm{ft} / \mathrm{mi}$ and the elevation decreases from 228 to $190 \mathrm{ft}$, as a result the stream channel of the middle reach is less steep than the upstream reach. The drainage basin area increases by $17.6 \mathrm{mi}^{2}$ in this reach. 


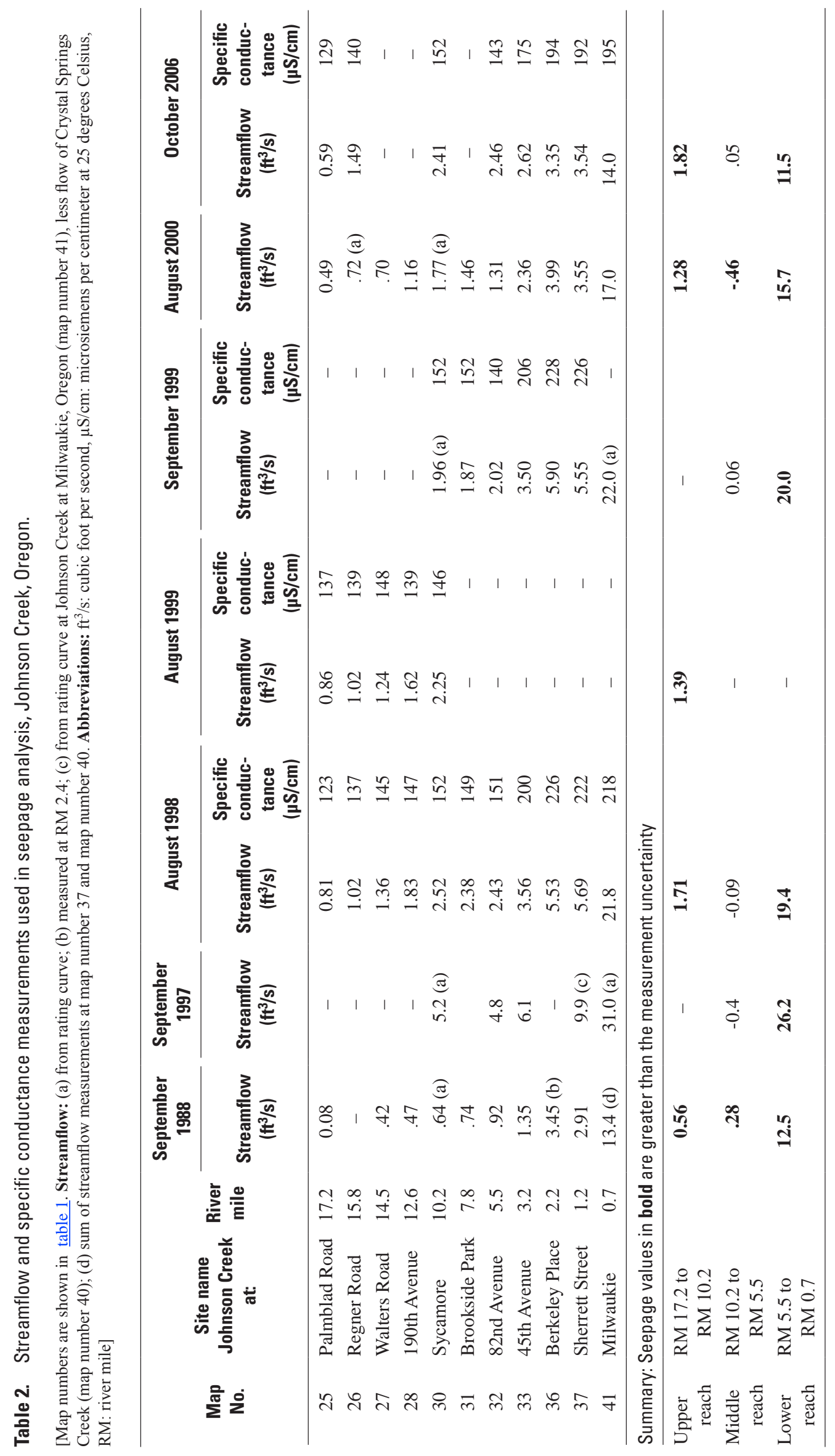




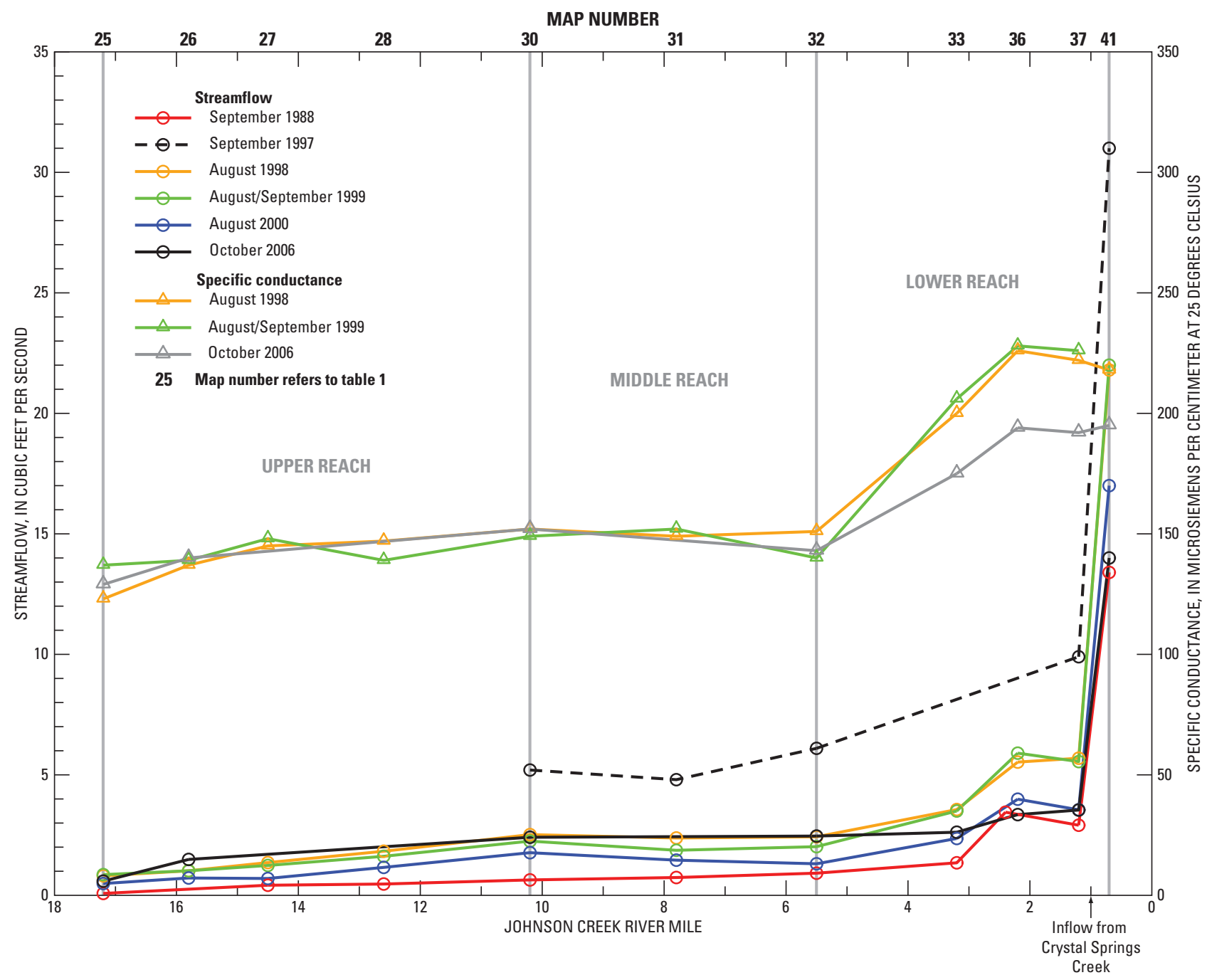

Figure 4. Seepage measurements during low flow in 1988, 1997-2000, 2006, and specific conductance measurements during low flow in 1998, 1999, and 2006, Johnson Creek, Oregon.

The contributing area to the middle reach on the southern side is similar to that of the upstream reach, except at the lower end of the reach, which is flat and composed of unconsolidated sediments. The contributing area on the northern side of the creek is relatively flat and consists of permeable Pleistocene flood deposits. The lower reach extends from RM 5.5 to 0.7 (pl. 1). The channel slope (35 ft/mi) is greater than that of both reaches upstream. Elevation decreases from 190 to $24 \mathrm{ft}$. The drainage basin area in this reach increases by $8.8 \mathrm{mi}^{2}$. The stream channel in this reach intersects a relatively large thickness of unconsolidated sediments of the terrace deposits, contributing to increased seepage. This reach includes Errol Spring and Crystal Springs Creeks and numerous other spring inflows.
Seepage measurements in the upper reach indicated relatively small gains during each study (fig. 4 , table 2). All gains in the upper reach were greater than the measurement uncertainty of 5 percent. Streamflow in this reach was not measured in 1997. During the September 1988 seepage run, the flow at the upstream end of this reach was only $0.08 \mathrm{ft}^{3} / \mathrm{s}$. Because the drainage basin size upstream of this location is $12.5 \mathrm{mi}^{2}$, this relatively low streamflow is an indication of minimal groundwater contribution to streamflow. The least gain in streamflow along this reach was in $1988\left(0.56 \mathrm{ft}^{3} / \mathrm{s}\right)$. The greatest gain was in $2006\left(1.82 \mathrm{ft}^{3} / \mathrm{s}\right)$. The gains decreased from $1998\left(1.71 \mathrm{ft}^{3} / \mathrm{s}\right)$ to $2000\left(1.28 \mathrm{ft}^{3} / \mathrm{s}\right)$, but were still more than twice the gains recorded in 1988. 


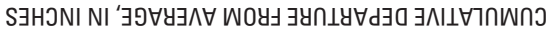

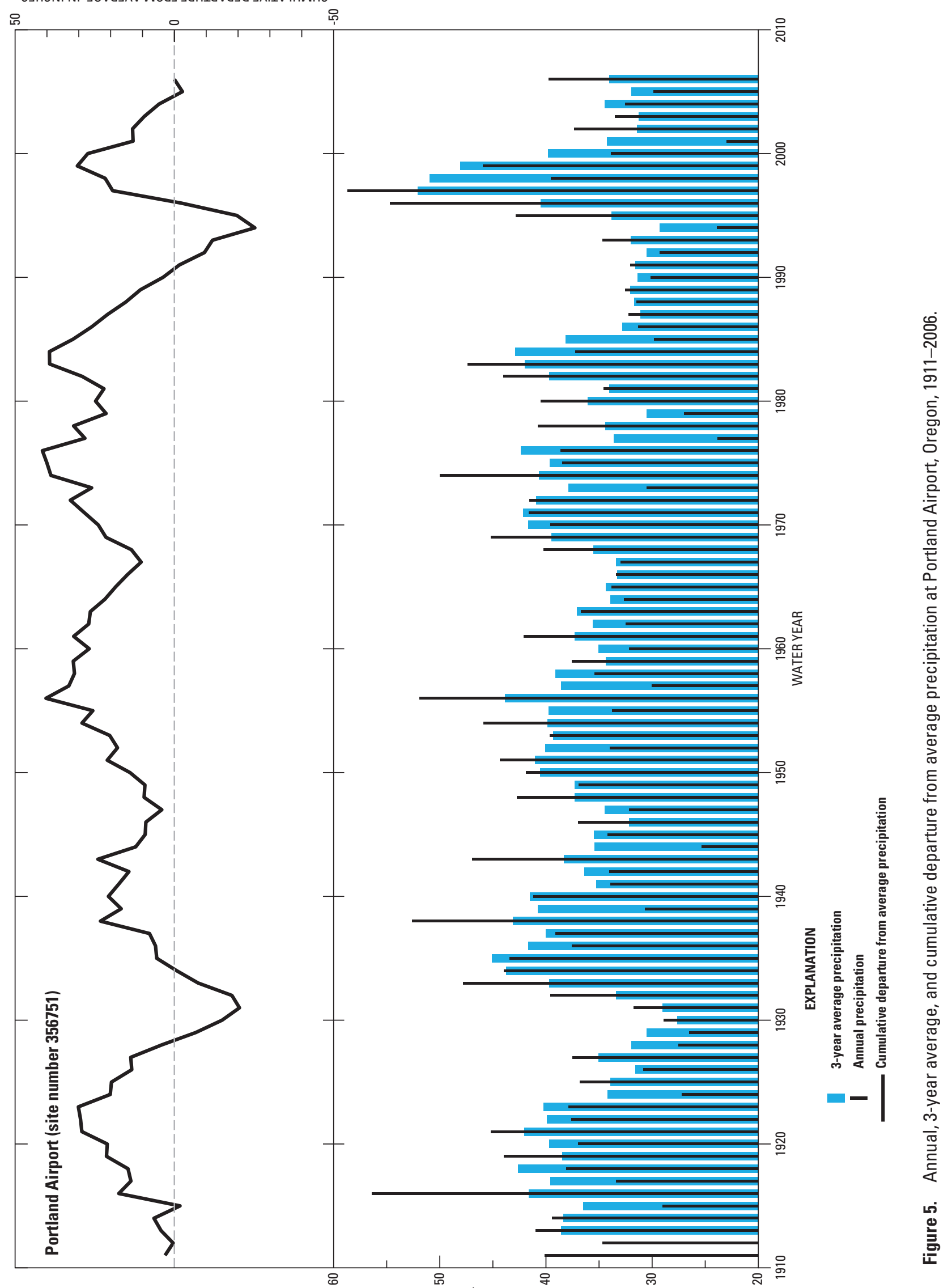


Seepage measurements in the middle reach indicated slight gains and losses; however, in 4 of the 6 years that measurements were made, the gains or losses were less than the measurement uncertainty. The only gain that was greater than the measurement uncertainty was in 1988 when streamflow gained $0.28 \mathrm{ft}^{3} / \mathrm{s}$. The only loss greater than the measurement uncertainty was in 2000 when the flow decreased by $0.46 \mathrm{ft}^{3} / \mathrm{s}$. These gains and losses are small considering the reach length and substantial increase in drainage basin area.

Gains in flow in the lower reach were much greater than in either of the two reaches upstream. The lower reach is characterized by diffuse seepage to the stream and by distinct spring inflows, the largest of which is Crystal Springs Creek. The least gain was in $2006\left(11.5 \mathrm{ft}^{3} / \mathrm{s}\right)$. The greatest gain was in $1997\left(16.2 \mathrm{ft}^{3} / \mathrm{s}\right)$, and gains generally decreased from 1997 to 2006. All gains in streamflow in this reach were greater than the measurement uncertainty. Streamflow in the lower reach indicated gains at each subsequent measurement location, except in some years between RM 2.2 and 1.2 (fig. 4). Losses between RM 2.2 and 1.2 may be attributed to recharge to groundwater through the streambed, as the stream gradient decreases and the stream channel intersects permeable deposits near the confluence with Crystal Springs Creek.

In summary, spring-flow and seepage measurements indicate that groundwater discharge to Johnson Creek is low in the upper and middle reaches, and high in the lower reach. In 1998, when spring flow (fig. 2) and seepage (fig. 4, table 2) were high, streamflow of Johnson Creek in the $11.7 \mathrm{mi}$ (encompassing an increase in drainage basin size of $31.9 \mathrm{mi}^{2}$ ) from RM 17.2 to 5.5 increased only $1.62 \mathrm{ft}^{3} / \mathrm{s}$. In contrast, in the relatively short $(4.8 \mathrm{mi})$ distance and small $\left(8.8 \mathrm{mi}^{2}\right)$ increase in drainage basin size from RM 5.5 to 0.7 , even in 1988, a relatively dry year, the stream gained $12.5 \mathrm{ft}^{3} / \mathrm{s}$.

\section{Long-Term Streamflow Data}

Long-term records of daily streamflow were used to quantify groundwater discharge to the stream in two ways. First, analyses were made of differences in low flows of Johnson Creek each year at the Gresham, Sycamore, and Milwaukie streamflow sites (map numbers 26, 30, and 41, respectively). Second, base-flow separation techniques were used to estimate the groundwater discharge component of streamflow at the Sycamore and Milwaukie sites. Comparison of the recharge and groundwater discharge derived from baseflow separation provides insight into the spatial distribution of groundwater discharge in the Johnson Creek basin.

Similar to the results of seepage measurements, analysis of low-flow data at the streamflow sites indicates differences attributable to groundwater discharge. Although the seepage measurements provided detailed spatial definition of groundwater discharge to the creek in specific reaches, and only during the years the seepage measurements were made, analyses of low flows from the streamflow sites provided a year-by-year indication of seepage to the stream.

The difference in low flow is shown in fig. 6 between the Gresham and Sycamore sites (from 1998 to 2006), and between the Sycamore and Milwaukie sites (from 1989 to 2006). At each site, the minimum flow is during late summer.

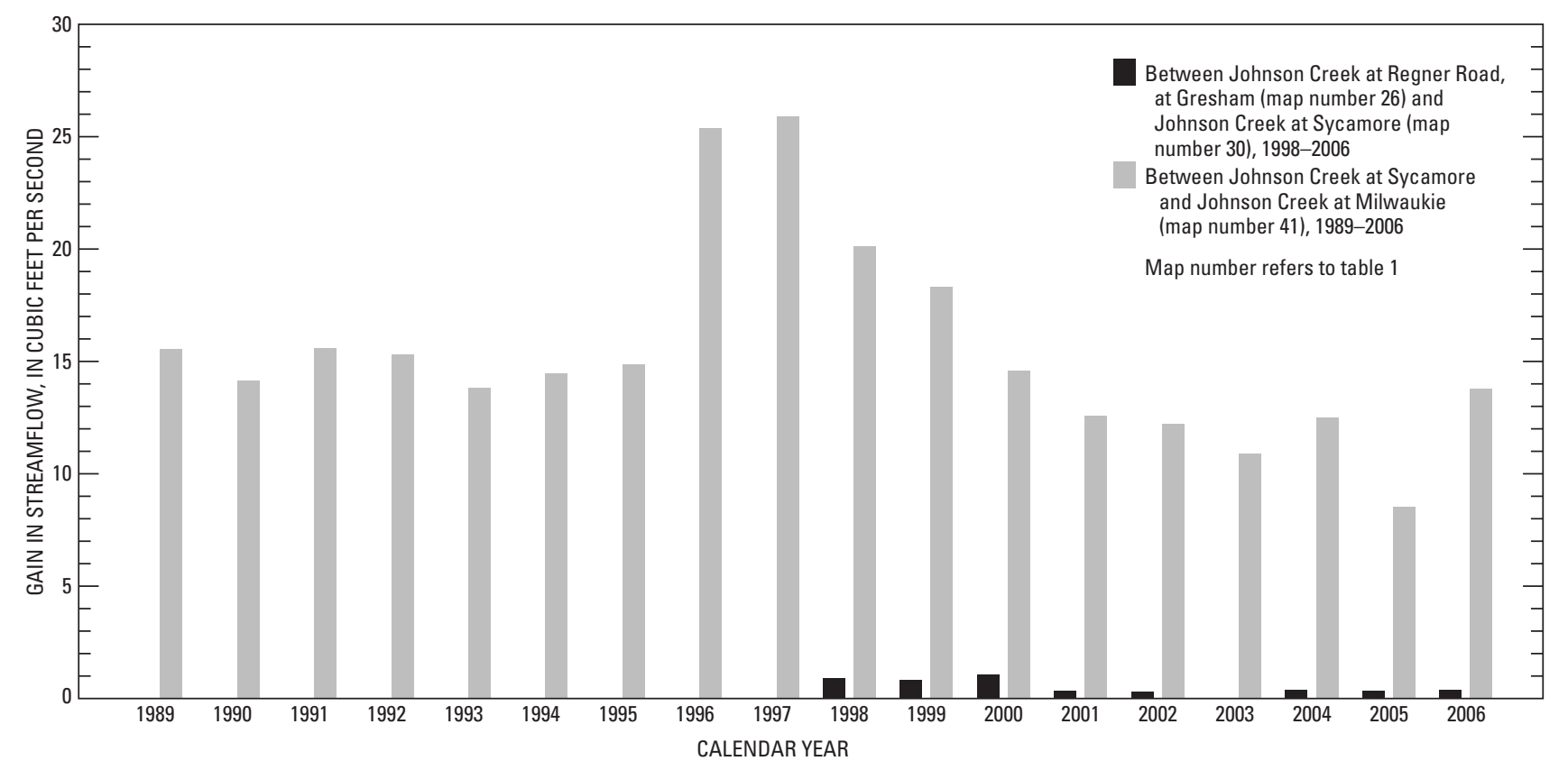

Figure 6. Gain in consecutive 7-day average low streamflow between Johnson Creek at Regner Road at Gresham, Oregon, and Johnson Creek at Sycamore, Oregon, and between Johnson Creek at Sycamore and Johnson Creek at Milwaukie, Oregon. 
The analysis was based on the same 7-day period at each site each year and was indexed to the days of minimum streamflow at the Sycamore site. For example, the 7-day low streamflow in 2005 at the Sycamore site was from September 21 to 27, and was compared to the 7-day streamflow for those days at the Gresham and Milwaukie sites. Although the annual 7-day minimum streamflow at the Gresham and Milwaukie sites may not coincide with that of the Sycamore site, differences in streamflow between the common period and the annual 7-day low flow at each site were usually within the uncertainty associated with the streamflow records. For each year, the 7-day flow from the upstream site was subtracted from that of the downstream site, resulting in the gain during the low-flow time of each year. The relatively large (about $1 \mathrm{ft}^{3} / \mathrm{s}$ ) groundwater discharge from Gresham to Sycamore in 1998 through 2000 was followed by a decrease to less than $0.4 \mathrm{ft}^{3} / \mathrm{s}$ beginning in 2001. In 2003, the stream lost about $0.3 \mathrm{ft}^{3} / \mathrm{s}$. Although only an indication of a loss, considering measurement uncertainties, the net groundwater discharge to this area of Johnson Creek during the summer of 2003 could be characterized as near zero. From 1989 to 2006, gains in flow from groundwater discharge to Johnson Creek between the Sycamore and Milwaukie sites were greater, ranging from 8.5 to $25.9 \mathrm{ft}^{3} / \mathrm{s}$. As discussed previously, most of the groundwater discharge is downstream of RM 5.5 and Crystal Springs is the largest contributor. The average summer gain in flow for 1996-99 was $22.4 \mathrm{ft}^{3} / \mathrm{s}$, compared to the 1989-95 average of $14.8 \mathrm{ft}^{3} / \mathrm{s}$ and the 2000-2006 average of $12.2 \mathrm{ft}^{3} / \mathrm{s}$. Use of low-flow data provides a minimum estimate of seasonal groundwater discharge to Johnson Creek. Groundwater discharge during the remainder of the year is higher because of increased infiltration of precipitation (recharge) and resulting increases in discharge to the stream from the surrounding aquifer.

For years when seepage measurements were made (1997 to 2000, and 2006), differences in streamflow measured at the Gresham, Sycamore, and Milwaukie sites were similar to differences in streamflow derived by comparison of 7-day low flows. The seepage measurements were made at low flow, but not necessarily at the lowest flow of the year. For this reason, groundwater discharge from seepage was usually slightly greater than determined from the 7-day low flows.

Several inherent factors contribute to uncertainty in estimation of seepage to the stream from groundwater discharge using the low-flow data. Streamflow is computed using a lookup table, also known as a "stage-discharge rating." ("Stage" is the stream level relative to an arbitrary datum.) At low flow, small changes in stream level result in relatively large changes in flow. Although streamflow measurements define the stage-discharge relation at a streamflow site, the relation can be imprecise and is affected by impermanent factors such as leaves, algae growth, and beaver dams. Similar to methods used in compiling seepage measurements, subtracting one small number from another also introduces uncertainty. Other factors that were not quantified include differences in evapotranspiration losses and possible water withdrawals. The lowest 7-day flow of the year at a given site additionally was not necessarily at the same time at all three sites because of the recession characteristics and differences in response to small rainfall events during the summer.

Base-flow separation also was used to quantify groundwater discharge to Johnson Creek, and to provide comparison between recharge estimates. This analysis is made using multidecade-scale, average streamflow values, and draws a comparison to long-term average recharge. Although recharge and discharge vary from year to year, these relatively short-term variations are dampened by the decadescale analysis. Snyder and others (1994) estimated recharge for the period from 1949 to 1983 . The streamflow records at the Sycamore site begin in WY 1941, and at the Milwaukie site in WY 1989. The base-flow component of streamflow at the Sycamore site was calculated for the period covered by the Snyder and others (1994) analysis, the period of record at the Sycamore site, and from WY 1990 to 2006, the period of concurrent record at the Milwaukie site. The difference in the average groundwater discharge between these periods was less than 10 percent. For comparison, the concurrent period of record of the Sycamore and Milwaukie sites (WY 1990-2006) was selected.

The average base-flow component of streamflow from WY 1990 to 2006 at the Sycamore site was about 20,500 acre-ft/yr and about 35,500 acre-ft/yr at the Milwaukie site. At each site, groundwater discharge (the base-flow component of streamflow) represents about 60 percent of estimated recharge. The remaining 14,000 acre-ft of recharge at the Sycamore site is assumed to leave the drainage basin upstream of the site by groundwater flow paths leading toward other points of discharge either downstream of the site or outside the Johnson Creek basin. The remaining 25,300 acre-ft at the Milwaukie site likely discharges to areas outside of the Johnson Creek basin. Possible discharge of water that recharges to the Johnson Creek basin to areas outside of the basin is discussed further in the section "Groundwater Flow Direction."

\section{Use of Environmental Tracers to Identify Groundwater Discharge}

A qualitative assessment of seepage was based on observations of specific conductance and continuous records of stream temperature. In this context, specific conductance and temperature were used as tracers to identify the presence of groundwater discharge in a given stream reach, providing independent confirmation of trends identified by flow measurements (Winter and others, 1998; Stonestrom and Constanz, 2003).

The specific conductance of groundwater typically is higher than surface runoff because of prolonged contact with and dissolution of minerals in the subsurface environment. For example, the specific conductance of Johnson Creek during 
high flows is usually less than $100 \mu \mathrm{S} / \mathrm{cm}$ compared to specific conductance values of greater than $200 \mu \mathrm{S} / \mathrm{cm}$ in Crystal Springs Creek, a groundwater fed stream (Edwards, 1992, p. 28). Increasing specific conductance from one measurement location to the next downstream generally is an indicator of groundwater discharge to the stream.

Specific conductance measurements were made at most locations during the 1998, 1999, and 2006 seepage studies. Specific conductance generally increased less than $30 \mu \mathrm{S} / \mathrm{cm}$ from RM 17.2 to the lower end of the middle reach (RM 5.5) (fig. 4, table 2). In contrast, specific conductance increased more than $50 \mu \mathrm{S} / \mathrm{cm}$ between RM 5.5 and 2.2. These results were consistent with the small gains in flow observed upstream of RM 5.5 and the much greater gains between RM 5.5 and 2.2. The absence of change in specific conductance from RM 2.2 to 1.2 is consistent with the absence of gain in streamflow indicated by the streamflow measurements. A large gain in streamflow is observed without a large increase in specific conductance between RM 1.2 and 0.7 because the gain is a result of inflow from Crystal Springs Creek, and at low flow, the specific conductance of Johnson Creek is similar to that of Crystal Springs Creek.

Stream temperature is another indicator of presence or absence of groundwater discharge. Seepage measurements are usually made during the summer, when air temperature is higher than the stream temperature. Groundwater discharge to the stream is cooler than either the stream temperature or the summer air temperature. During the summer, the temperature of Johnson Creek fluctuates on a diurnal cycle, warming several degrees during the day and cooling at night. In contrast, groundwater temperature is much cooler and fluctuates little. For example, the temperature of two springs (spring identification numbers 12 and 15 as shown in McCarthy and Anderson, 1990, table 2) in the Crystal Springs area was a constant $12.6^{\circ} \mathrm{C}$ from May to August 2000, despite seasonably warm air temperatures.

Groundwater discharge is identified by an overall cooling of the stream in the summer and moderation of the magnitude of the diurnal fluctuation in temperature. In the absence of groundwater discharge to the stream in a given reach, the diurnal pattern of stream temperature is repeated at subsequent locations downstream, generally warming because of increased exposure of the stream to the warm air and to solar radiation along many of the reaches. Groundwater discharge to the stream is identified by comparing the temperature at the upstream and downstream end of a given reach.

Temperature recorders were installed in the stream at each streamflow location during the seepage studies of 1998 and 2000 for several days before and after the day of streamflow measurements. An example of the stream temperature is shown in figure 7 at three locations on Johnson Creek in 2000, and the results shown are similar to those of 1998. The stream temperature was fairly similar between RM 7.8 and 5.5, indicating negligible groundwater discharge to the stream, and substantiated by seepage measurement, which indicated little change in streamflow (fig. 4, table 2). In contrast, streamflow increased from RM 5.5 to 3.2 and was accompanied by an overall decrease in stream temperature.

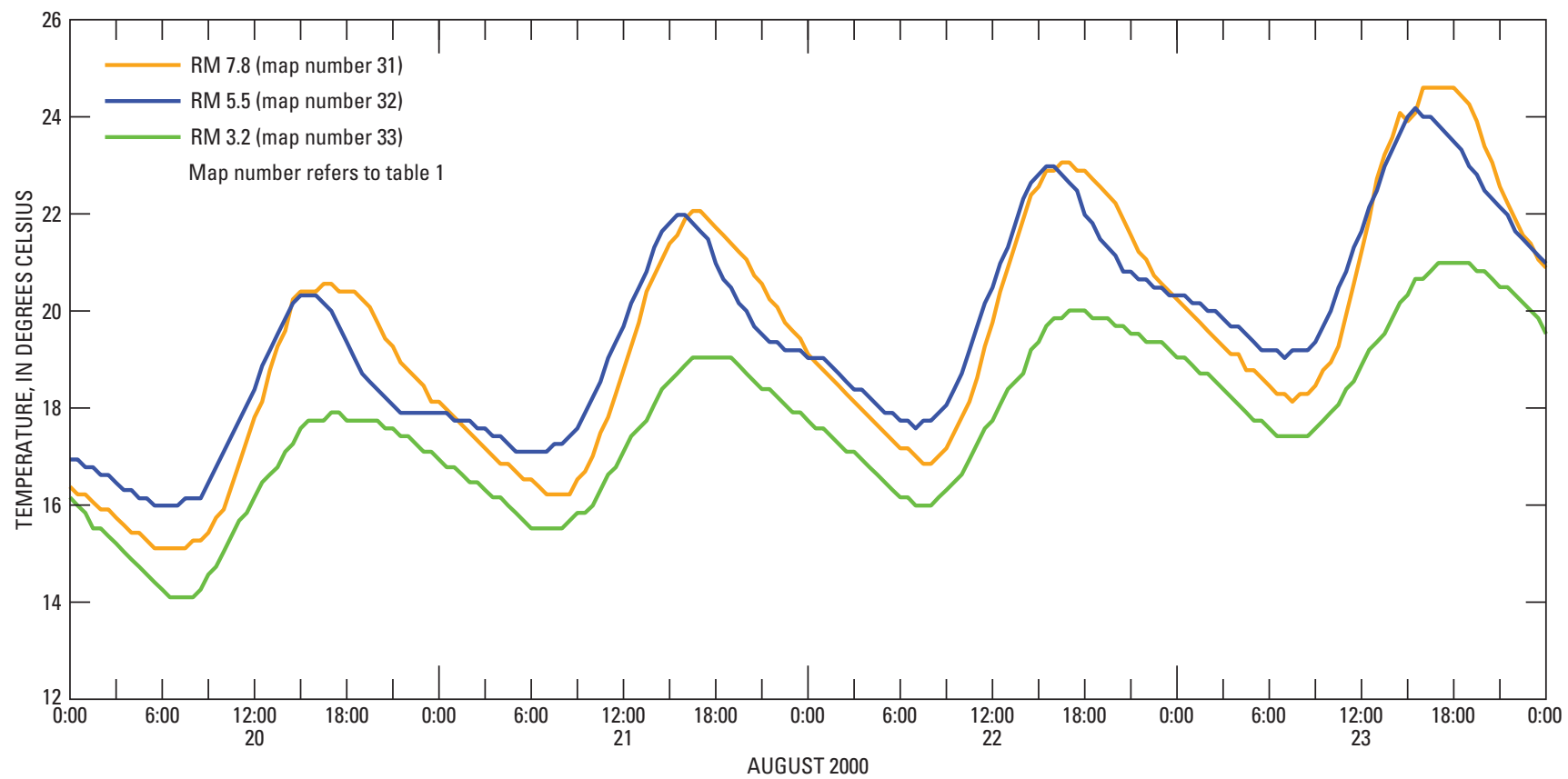

Figure 7. Temperature at river mile (RM) 7.8, RM 5.5, and RM 3.2, Johnson Creek, Oregon. 


\section{Groundwater Flow Direction}

An understanding of groundwater flow direction is useful in evaluating the source areas (referred to as the contributing areas) for features that may receive groundwater discharge such as streams, lakes, wetlands, springs, and wells. If the location and extent of the contributing areas for discharge features is identified then information can be provided about how natural and man-made changes in climate, water use, or land use, for example, can influence the quantity and quality of water that may discharge. Therefore, knowledge of the direction of groundwater flow can be used to improve our understanding of the hydrology of the Johnson Creek basin, which will facilitate effective management of the water resources.

The direction of groundwater flow in an aquifer is dependent on the hydraulic head, an indicator of the total energy available to move groundwater through an aquifer (Taylor, and Alley, 2002, p. 3). Hydraulic head differs from the water level which describes the position of the groundwater surface usually relative to some datum such as sea level. For the water table, the hydraulic head is equal to the water-level elevation. For a vertical position in the water column below the water table or under confined conditions, the hydraulic head is the sum of the elevation of the position and fluid pressure at that point (the contribution to the hydraulic head from kinetic energy as a result of flow typically is assumed to be negligible) (Freeze and Cherry, 1979, p. 18-22, 39; Taylor, and Alley, 2002, p. 3). The hydraulic head at some point in an aquifer, such as a narrow open interval for a well, typically is measured as the height (water level) to which a column of water will stand above some datum. Groundwater flows from areas of high hydraulic head to areas of low hydraulic head. The direction of groundwater flow is used to identify the presence of a groundwater flow divide (a ridge in the groundwater surface from which groundwater moves away in both directions perpendicular to the ridge line), which is useful in inferring the extent of contributing areas to groundwaterdischarge features such as streams and springs. However, groundwater moves in complex, three dimensional patterns that change with time and consist of vertical and horizontal components of flow (Franke and others, 1998, p. 12). Water-level maps are useful in determining the approximate horizontal direction of groundwater flow but should be used with caution and the knowledge that a vertical component of flow also is present and that the direction of lateral flow may vary with depth below the water surface.

Groundwater flow directions in the Johnson Creek basin were inferred from water-level maps determined directly from measurement of groundwater elevations (McFarland and Morgan, 1996) and groundwater flow modeling that simulates the physical properties of the groundwater flow system and the stresses applied to the system to calculate hydraulic heads
(Morgan and McFarland, 1996). A USGS study of the depth to groundwater and configuration of the water table in the Portland metropolitan area by Snyder (2008) resulted in a map of the estimated water-table elevation. The water-table map utilized much of the groundwater data collected as part of this study and can be used to infer the direction of groundwater flow on a local scale (Snyder, 2008, p. 5). The results of the analysis by Snyder (2008, p. 28, pl. 2) (see fig. 8) and analyses by McFarland and Morgan (1996, pls. 2-3) and Morgan and McFarland (1996, pls. 3-4) indicate that in many areas of the Johnson Creek basin, the direction of groundwater flow is not toward Johnson Creek, but instead is out of the drainage basin towards the Sandy, Columbia, or Willamette Rivers. Upstream of about RM 21, the direction of groundwater flow in the Johnson Creek basin generally is northward to the Sandy River. Between RM 21 and 15, the direction of groundwater flow is towards Johnson Creek. Between RM 15 and 3, groundwater flow may be towards Johnson Creek in the immediate vicinity of the creek. However, between RM 15 and 3 , groundwater may flow north to the Columbia River in the eastern reach, with flow becoming more westerly towards the Willamette River in the western part of this area. Downstream of RM 3, in the lower part of the Johnson Creek drainage basin, the direction of groundwater flow at the water table is more consistently toward Johnson Creek, indicating local groundwater discharge.

The greater relative streamflow observed in the lower reaches of the Johnson Creek basin compared to the upper and middle reaches is likely explained by discharge from intermediate and regional groundwater flow systems in these areas. The general direction of shallow and intermediate depth groundwater flow in the middle and eastern areas of the Johnson Creek basin (containing the middle and upper reaches of Johnson Creek) generally is toward the Columbia River north or northwest, away from Johnson Creek (fig. 8; McFarland and Morgan, 1996, pls. 2-3; Snyder, 2008, pl. 2). Vertical hydraulic gradients between the water table and the underlying hydrogeologic unit and between the water table and deeper hydrogeologic units as simulated by Morgan and McFarland (1996, p. 32-35) additionally indicate downward movement of water throughout most of the eastern area of the Johnson Creek basin. In the middle areas of the basin, the vertical gradients are mixed. In the western area of the Johnson Creek basin, the general direction of shallow and intermediate depth groundwater flow is northwest changing to west towards the Willamette River and the mouth of Johnson Creek in the westernmost area of the basin. Vertical hydraulic gradients in the westernmost area of the basin indicate upward gradients that may denote the discharge of intermediate and regional groundwater flow to the lower reaches of Johnson Creek, tributaries and springs in the area, or to the Willamette River. 


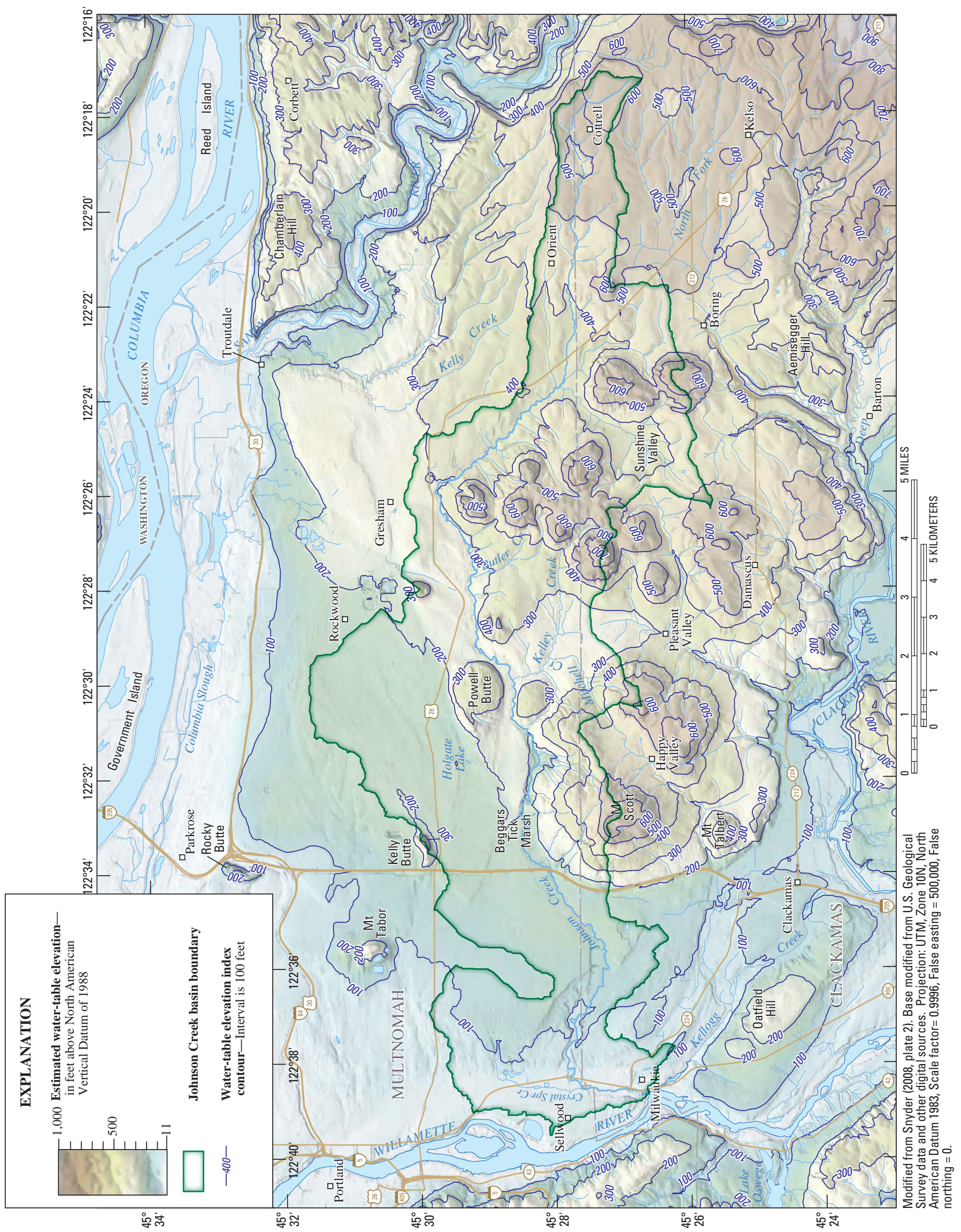

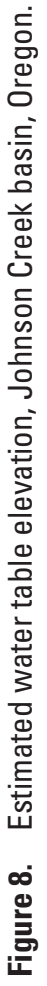


The apparent absence of groundwater discharge to some reaches of Johnson Creek is further indicated by a particletracking analysis (the simulation of hypothetical particles of water through the groundwater flow system using the results of a groundwater flow model) by Hinkle and Snyder (1997). The results of Hinkle and Snyder (1997) indicate that groundwater that recharges in areas of the Boring Hills flows vertically down and north beneath Johnson Creek through the regional groundwater flow system and likely discharges to the Columbia River (Hinkle and Snyder, 1997, p. 20 and pl. 1 A, $B$, and $C$ ).

These observations and analyses indicate that the surfacewater divides delineating the Johnson Creek drainage basin are not necessarily coincident with groundwater divides particularly along the northern boundary of the basin. The surface-water divides along the southern boundary of the basin generally are coincident with the groundwater divides with possible exceptions in the vicinity of Happy and Pleasant Valleys, where areas of the valleys may be within the groundwater contributing area of the Johnson Creek basin although they are within the surface-water basins for Mt. Scott and Rock Creeks, respectively. As a result, recharge to the groundwater system within some areas of the Johnson Creek surface-water drainage basin may not discharge to Johnson Creek and instead may flow and discharge to regional groundwater discharge areas such as the Columbia and Willamette Rivers. Discharge of groundwater to areas outside the Johnson Creek basin appears to be more prevalent in the eastern and northern areas of the basin. This conclusion is further supported by the observations based on seepage measurements and streamflow data that indicate relatively small gains to Johnson Creek in the upper and middle basin compared to the lower basin.

\section{Variation in Groundwater Levels and Storage}

Understanding the factors that affect the location, timing, and magnitude of variations in groundwater levels and storage will aid managers in development of guidelines and regulations to protect the groundwater and surface-water resources of the Johnson Creek basin. Water-level fluctuations in wells represent variations in groundwater storage and are a result of many factors, including aquifer properties, the rates of recharge or discharge, the direction and magnitude of groundwater flow, and the construction of the well. In the Johnson Creek basin, the fluctuation of groundwater levels and storage is of particular concern because of the influence of these factors on the magnitude and timing of spring discharge, streamflow, and the surface expression of the water table in low-lying areas.

Changes in the rates of recharge or discharge cause changes in groundwater storage, which are represented by water-table fluctuations. The water table rises because of increased groundwater storage when the rate of recharge exceeds the rate of discharge and declines when these conditions are reversed (Veeger and Johnston, 1996, p. 28).
The water table rises in response to increased groundwater storage that can result from recharge because of precipitation, losing streams, stormwater runoff into UIC systems, infiltration from septic systems and excess irrigation, or increased inflow of groundwater from adjacent areas. The water table declines in response to decreased groundwater storage that can result from discharge to gaining streams, springs, pumpage, evapotranspiration, or the outflow of groundwater to adjacent areas. In the Portland area, the quantity and timing of precipitation typically exerts the greatest influence on water-level fluctuations, and because of the seasonal nature of precipitation, a seasonal response in water-table level results (Snyder, 2008, p. 24-25, 29-30). Groundwater levels rise following precipitation of sufficient intensity and duration to exceed evapotranspiration and soil moisture deficits and the residual infiltration results in recharge. Water levels decline as groundwater is removed from storage during periods when discharge to rivers, streams, springs, pumping wells or evapotranspiration, is greater than recharge. Time scales for water-table fluctuations range from hours (in the response to high intensity precipitation events or changes in stream level) to years or decades (in response to long-term changes in climate or land-use practices).

Well construction also can influence water-level fluctuations in wells. The well depth, the open-interval length and its proximity to the water table, and if the well is open to a water-table (unconfined) aquifer or confined aquifer can all contribute to water-level fluctuations in wells.

Changes in groundwater storage indicated by fluctuations in groundwater levels are of special interest in two areas within the Johnson Creek basin: (1) the groundwater contributing area to Crystal Springs (which provides the flow to Crystal Springs Creek (map number 40) that consequently provides most of the late summer flow to Johnson Creek downstream of the confluence with Crystal Springs Creek), and (2) the vicinity of Holgate Lake (map number 43) that is subject to flooding when groundwater levels exceed landsurface elevation in low-lying areas.

The surface-water contributing area to Crystal Springs Creek is insufficient to supply the observed discharge based on estimates of groundwater recharge (Dames \& Moore, 1998, p. 59). The groundwater contributing area for the flow to Crystal Springs, which supplies most of the discharge to Crystal Springs Creek, may extend to areas well beyond the surface-water contributing area of the Crystal Springs Creek basin perhaps as far east as Powell Butte according to observations of regional and local groundwater flow directions (McFarland and Morgan, 1996, pls. 2-3; Snyder, 2008, pl. 2). However, an accurate delineation of the groundwater contributing area for Crystal Springs will require the use of an updated three-dimensional groundwater flow model with sufficient discretization and data to adequately represent the springs and gaining and losing reaches of Johnson Creek. The change in groundwater storage in this area may have a direct relation to the timing and quantity of streamflow of Crystal Springs Creek. 
Analysis of the groundwater flow system was focused on the area extending from Powell Butte westward which includes the areas of Crystal Springs Creek and Holgate Lake, two concerns to the community. A monitoring network of wells was established in 1998 to increase understanding of the groundwater flow system in the area. Initially, the wells were measured monthly, changing to bimonthly in 2000, and to quarterly beginning in 2005. Hydrographs from these wells were used to analyze the spatial and temporal variations in groundwater levels in the western area of the Johnson Creek basin (fig. 9; pl. 1; table 1). In 1998 a continuous waterlevel recorder with real-time telemetry was installed near Holgate Lake (map number 9). In 2001, the city of Portland completed construction of seven monitoring wells between I-205 and Westmoreland Park. Continuous water-level recorders were installed in five of these wells (map numbers $19,20,21,23$, and 24). The records from the continuous water-level recorders at Holgate Lake and between I-205 and Westmoreland Park provide the most detailed information on the magnitude and timing of groundwater fluctuations in the area west of Powell Butte (igss. 10 and $\underline{11}$ ). This information was used to evaluate how groundwater storage changes from day to day, season to season, or year to year in response to precipitation events, seasonal variations, or long-term trends, respectively.

Water levels in the four easternmost wells with continuous water-level recorders (ig. 10) fluctuated in response to precipitation (fig. 11). The general pattern of water level in these four wells is a sinusoidal fluctuation that varies seasonally. From east to west, the magnitude of the response is increasingly attenuated and the time between precipitation and the corresponding rise in water level is increased. The annual water-level fluctuation (ig. 10) ranges from as much as $10 \mathrm{ft}$ in the easternmost well (map number 9) to less than a foot in the westernmost well of this group (map number 21). In a given year, the water level in the easternmost well responds quickly to the autumn rains, rising rapidly following distinct rainy periods, and usually peaks in March or April, coincident with the end of the rainy period and the beginning of substantial uptake of water by plants and evaporation. The rise in water levels illustrated by this set of the four easternmost wells with continuous recorders is increasingly muted and delayed with distance westward (from east to west: map numbers 9, 19, 20, and 21), such that the response from autumn rains in the westernmost well of these wells does not usually begin until March or April of the following year, a 6-month difference. In 2001 and 2005, precipitation was decreased or fell later than normal (ig. 11) and seems to have contributed less to groundwater recharge due to decreased infiltration or uptake by soil moisture storage and evapotranspiration compared to other years as indicated by a lower than normal rise in the groundwater level at the easternmost well (map number 9), and little or no increase in groundwater levels in the other wells shown in figure 10, until the following season's recharge from precipitation. The increase in the attenuation and delay of the rise in the level of groundwater in response to the autumn and winter precipitation in an east-to-west direction may be attributed to the characteristics of the unsaturated zone, such as thickness and composition. The unsaturated zone thickness is one of the factors affecting the travel time of precipitation from the land surface to the water table and greater thickness contributes to longer and more diverse travel times. The median daily thickness of the unsaturated zone is about $44 \mathrm{ft}$ in the easternmost well, and is about 120, 131, and $100 \mathrm{ft}$ in the other three wells from east to west, respectively (fig. 10). Unsaturated zone travel time also is a function of several factors, including the composition of the unsaturated zone including rock type, particle size/texture (clay, silt, sand, and gravel), sorting, consolidation, cementation, homogeneity, and moisture content. The unsaturated zone materials consist primarily of unconsolidated deposits from the Missoula Floods. These deposits tend to be finer grained to the west as distance increases from the western end of the Columbia River Gorge (Trimble, 1963, p. 63; Hogenson and Foxworthy, 1965, p. 26). However, these materials can be variable and discontinuous vertically and laterally (Trimble, 1963 , p. 58-62). The presence of poorly sorted finer grained materials may further increase the time and diversity of travel times through the unsaturated zone. Differences in effective porosity of these materials also could result in differences in the magnitude of the response to precipitation events, such that greater effective porosity results in greater storage available within the aquifer and a smaller change in the watertable position resulting from a change in a given volume of water when compared to an aquifer with a lesser effective porosity (Snyder, 2008, p. 24-25, 29-30).

Alternatively or additionally, there may be a groundwater wave (hydraulic pulse) in the saturated zone moving from east to west when recharge enters the groundwater flow system and moves laterally. A groundwater wave is defined as "a high in the water table that moves laterally, with a wavelike motion, away from a place where a substantial quantity of water has been added to the saturated zone within a brief period" (Wilson and Moore, 2003, p. 97). A groundwater wave originating in the area on the west side of Powell Butte and moving westward could explain the pattern of water-level fluctuations in the wells from Powell Butte extending west to the area just east of Westmoreland Park. The pattern displays increased attenuation and delay of the rise in the level of groundwater as distance increases from the source area. A groundwater wave is an expression of a hydraulic (pressure) pulse that can move more rapidly through an aquifer when compared to the actual movement of groundwater, which would be expected to be much slower. The existence of a groundwater wave may be resolved by further analysis of existing or new groundwater level data in this area. 

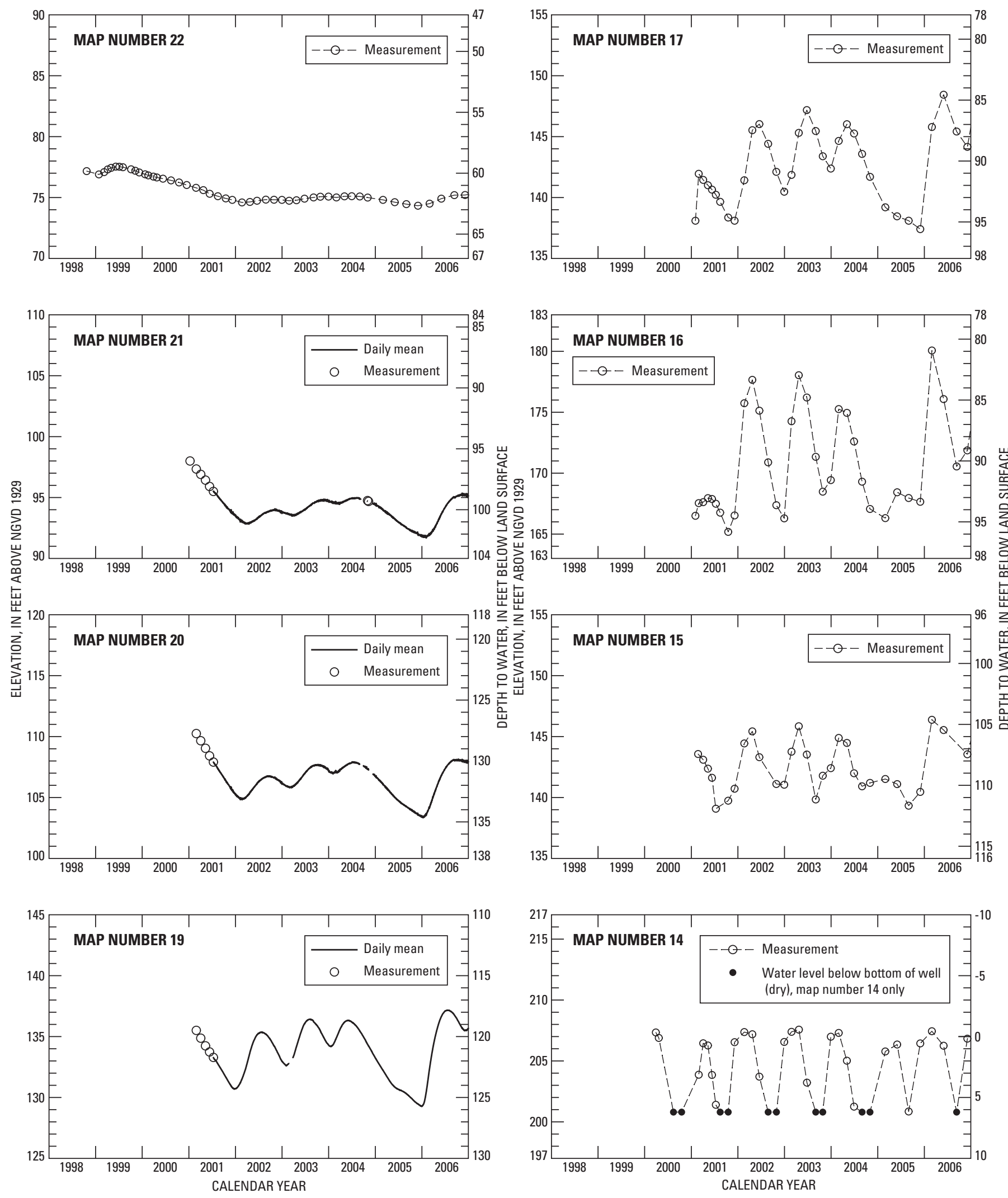

Figure 9. Water levels in selected long-term observation wells, Johnson Creek basin, Oregon. Map numbers refer to table 1. 

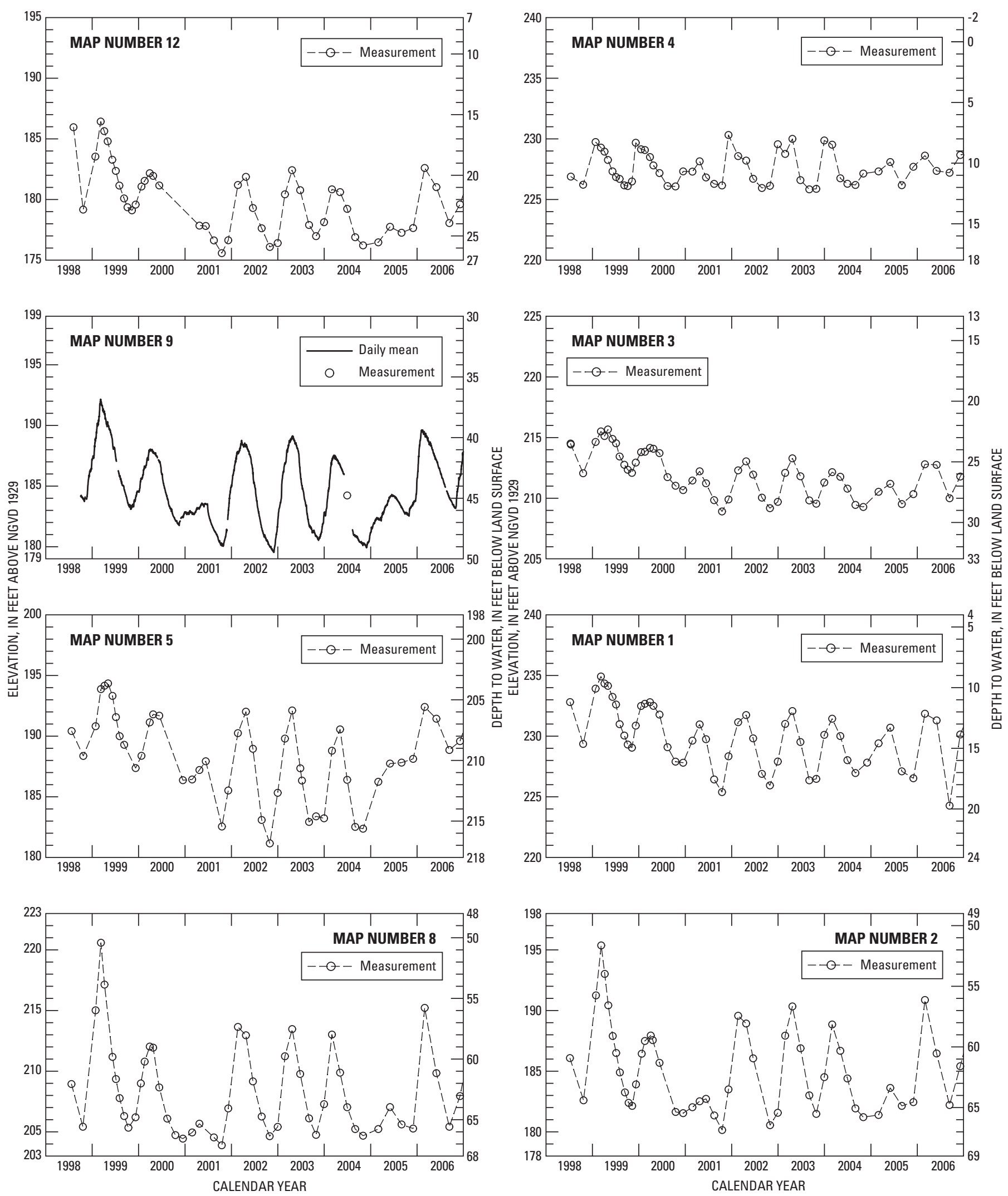

Figure 9.-Continued 

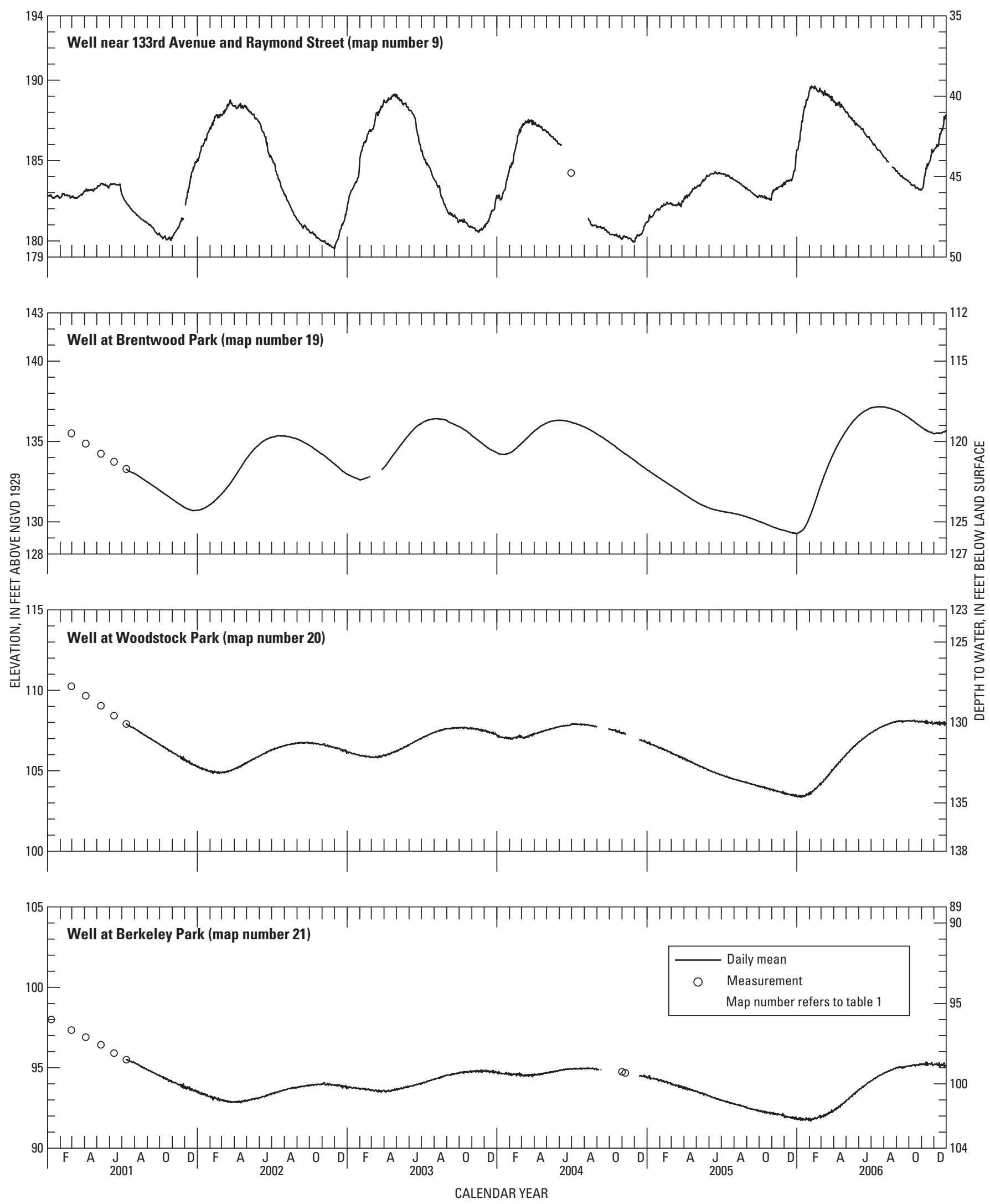

Figure 10. Water level elevation and depth to water in wells: near 133rd Avenue and Raymond Street, at Brentwood Park, at Woodstock Park, and at Berkeley Park, Portland, Oregon. Map numbers refer to table 1.. 

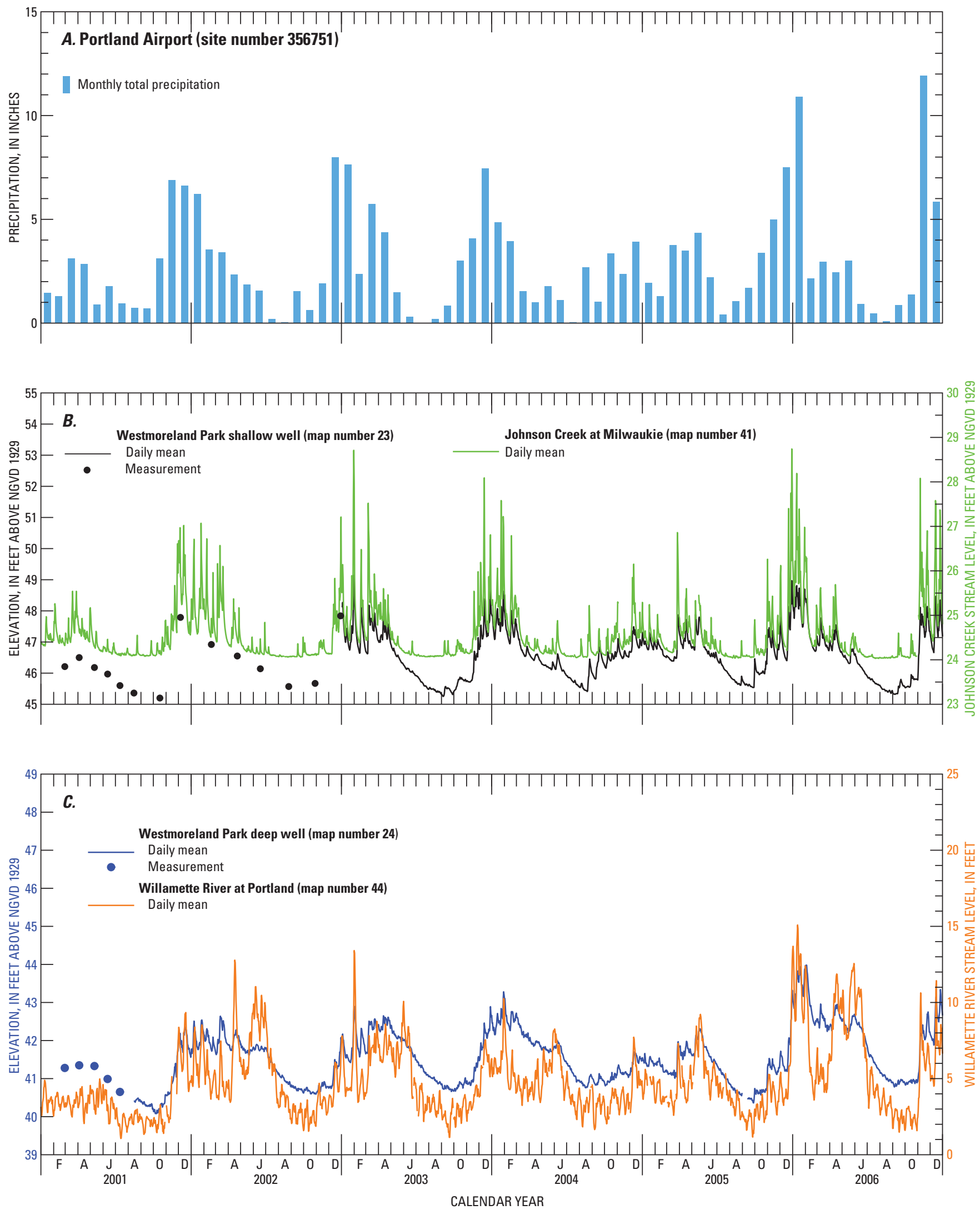

Figure 11. Precipitation at $(A)$ Portland Airport, Oregon, $(B)$ water level elevation in the shallow well at Westmoreland Park and water level of Johnson Creek at Milwaukie, Oregon, and $(C)$ water level elevation in the deep well at Westmoreland Park, and level of the Willamette River at Portland, Oregon. (Willamette River stream level is set to an arbitrary gage datum. Map numbers refer to table 1.) 
Understanding of the pattern of water-level fluctuations in the two Westmoreland Park wells is needed to assess the possibility of a relation of groundwater levels in this area to the level and streamflow of Crystal Springs Creek in the Westmoreland Park area. The patterns of water-level fluctuations in the two wells in Westmoreland Park (a shallow well (map number 23), and a deeper well (map number 24); fig. 11) are fairly similar, but differ greatly when compared to the four continuous-recorder wells toward the east (fig. 10). The different trends in water levels are a result of two factors. First, the Westmoreland wells are completed in permeable deposits of a former stream channel that could be either of the Clackamas River or of the Willamette River (Hogenson and Foxworthy, 1965, p. 10-11, 28). The channel facies deposits consist of interlayered silts, sands, and gravels, which in some places are locally covered by bog or pond sediments (Beeson and others, 1989). These deposits may exert a strong influence on the response of water levels within the groundwater system. Second, proximity to Johnson Creek and the Willamette River indicates that changes in the hydraulic head of these streams (as represented by their surface-water elevations) may be transmitted through the permeable channel facies deposits and affect water levels in the Westmoreland Park wells as indicated from the hydrograph characteristics for the two wells (see discussion below). Water levels in the two Westmoreland Park wells are relatively close to land surface, where depth to water from 2001 to 2006 was about 3 to $12 \mathrm{ft}$ below land surface.

The water level in both Westmoreland Park wells rises quickly in response to precipitation, and also rises and declines on an annual cycle (fig. 11). Following the end of a given precipitation event, the water level in these wells declines rapidly. This rapid decline in water level in the Westmoreland Park wells is unlike the wells to the east, where the effect of precipitation typically is cumulative within a given year, and water levels begin to decline slowly in response to decreased precipitation intensity and groundwater flow towards discharge areas (fig. 10). Of the two wells in Westmoreland Park, the shallow well (map number 23) responds slightly more quickly, and the rise generally is of greater magnitude than the deep well (map number 24). Response time of both wells to precipitation is within 1 to several days. Most of the water-level rise associated with a typical several-day winter storm with 2 to 3 in. of rainfall is often about $2 \mathrm{ft}$ in the shallow well and about $1 \mathrm{ft}$ in the deep well. The short-term rise and decline in water level because of discrete rainfall events is superimposed on an annual, relatively steep rise in water level in autumn and winter and an attenuated recession during the spring and summer periods. Water levels in these two adjacent wells at Westmoreland Park were compared to precipitation at the Portland Airport (NWS site number 356751) (Oregon Climate Service, 2007). Weekly precipitation totals show a moderate correlation with the weekly change in groundwater levels at the shallow and deep well, with a correlation coefficient (R) of 0.60 and 0.65 , respectively.
Although rises in water level in both wells are on a severalday time scale, these rises are followed by declines on the same time scale. These declines in water level may account for the relative weakness in this correlation. Water levels in these wells show stronger correlations with stream levels in Johnson Creek and the Willamette River. The hydrographs of the two Westmoreland Park wells bear a striking similarity to the river-level hydrographs of Johnson Creek and the Willamette River (fig. 11) - similar shape and distinct storm and annual sinusoidal responses. Daily water levels in the shallow well (map number 23) are closely correlated $(R=0.85)$ to the daily mean stream level at the Johnson Creek at Milwaukie site (map number 41), and are at least in part affected by tidally induced fluctuations of the Willamette River. Although the well is about $1.5 \mathrm{mi}$ north of the Johnson Creek stream monitoring site, the closest approach is only about $0.7 \mathrm{mi}$ north of Johnson Creek. There seems to be a subsurface hydraulic connection between the shallow well and Johnson Creek because the lag time between a change in stream level and a corresponding change in the water level at the well is less than 1 day as determined using a cross-correlation analysis. At about RM 2.0, where Johnson Creek flows out of an incised canyon, the streambed consists of recent alluvial deposits that overlie the channel facies deposits at the mouth of the canyon (Beeson and others, 1989). At this location, the elevation of Johnson Creek is several feet above the elevation of the water table in the low-lying drainage basin of Crystal Springs Creek. Changes in stage in Johnson Creek likely are transmitted through the shallow, semi-confined channel facies deposits, to the Westmoreland Park wells. Potential recharge to the aquifer from Johnson Creek has been indicated by seepage measurements, which often indicate small losses along this reach to just upstream of the confluence with Crystal Springs Creek (fig. 4, table 2).

Backwater from tidal fluctuations of the Willamette River, about $0.8 \mathrm{mi}$ to the west, also affects the water level in the shallow Westmoreland Park well. Backwater is the effect on the water-surface elevation at a given stream location from fluctuations of a downstream water body. The Willamette River fluctuations of several feet per day (as observed at the site in downtown Portland (map number 44) about 3 river miles downstream) are transmitted to the shallow well through permeable channel deposits, resulting in a fluctuation of a few hundredths of a foot, daily and sometimes twice daily.

The daily mean water level in the deep well (map number 24) at Westmoreland Park also exhibits a strong correlation with the daily mean level of the Willamette River. The lag times in response to changes in level of the Willamette River and subsequent changes in the water level in the deep well at Westmoreland Park are short, perhaps less than 1 day as determined through cross-correlation. This strong correlation ( $R=0.81)$ and short lag time may be the result of a hydraulic connection between the Willamette River and the channel facies deposits within the former river channel that extend to the Willamette River and to which the deep well is open. As 
indicated above, a minor relation is apparent in the connection of tidal fluctuation in the Willamette River to the shallow well in Westmoreland Park. The deep well responds more reliably to the twice-daily tidal fluctuations, where two highs and two lows during many days affect the water level in this well. Similar to the shallow well, the amplitude of these fluctuations is several hundredths of a foot. The difference in the tidal effect observed in the shallow and deep wells may be attributed to a coarsening of subsurface materials at depth. The driller's logs of these two wells indicated a silty layer about $20 \mathrm{ft}$ below land surface near the open interval of the shallow well, which may inhibit movement of water from the otherwise coarse alluvial deposits to the shallow well.

The tidal influence and backwater from the Columbia River affect the Willamette River and these fluctuations also affect the water level in the Westmoreland Park deep well (fig. 11). Although the high-flow period of the Willamette River (and associated high stream level) usually is in winter, the spring melt in the headwaters of the Columbia River basin (several hundred miles to the northeast) in May and June of each year raises the Columbia River in the Portland area, backing water up in the Willamette River in the Portland area. The backwater creates a "hump" in the otherwise (usually) smooth recession of the Willamette River at Portland (map number 44). This rise is not associated with precipitation in the area and provides clear differentiation between precipitation and river-level induced changes in water level in the Westmoreland Park deep well. Evaporative losses additionally are high during late spring and effectively reduce recharge from precipitation in the May-June time period. The backwater effect is not the same each year, and depends primarily on the magnitude and duration of high flow of the Columbia River. For example, the presence of backwater was almost nonexistent in 2001, when May and June flows of the Columbia River were at a near-record low, but was present in 2006, an average flow year for the Columbia River.

\section{Response of the Groundwater System to Precipitation Extremes}

The response of the groundwater system to extended periods of either unusually high or low precipitation is manifested by changes in groundwater levels and discharge to rivers, streams, and springs. The period of study, 1997-2006, encompassed relative extremes in annual precipitation which were accompanied by changes in groundwater levels, streamflow, and spring discharge. The analysis of data collected during this period enabled the development of relations to forecast the effect of these precipitation extremes on groundwater levels and the resulting effect on surface-water features. These relations can be used to anticipate changes in discharge of spring-fed streams or to estimate the expected inundation of low-lying areas as a result of groundwater levels rising above land surface.

\section{High and Low Groundwater Discharge: Crystal Springs Creek}

Crystal Springs Creek receives flow from several springs, flows in a channel through park and residential areas of Southeast Portland, and enters Johnson Creek at RM 1.0. Historically, increased discharge of these springs has raised concerns about the stream level and potential flooding of areas adjacent to Crystal Springs Creek. Flooding was reported in park and residential areas adjacent to the creek in July 1997 (Chestnut, 1997). In 2005, low flow of Crystal Springs Creek in the Reed College area prompted concern about fish survival under these conditions.

The channel of Crystal Springs Creek has been modified. Although the creek is a natural feature, the mostly predevelopment landscape, as mapped by the General Land Office in 1852, consisted of a distinct stream channel in the upper area near the present location of Reed College campus, tributaries corresponding to the location of several springs in 2008, and an extensive wetland area covering much of what is now Westmoreland Park (University of Oregon, 2006). The wetland narrowed to a single stream channel near the confluence with Johnson Creek. The creek was channelized through much of its length in 1936 during construction of Westmoreland Park. The present configuration is an approximately 10 -ft-wide natural bottom, concrete-walled channel, where the creek flows nearly bankfull year-round. The stream channel opens into a pond in Westmoreland Park and narrows again toward the mouth of the creek.

Flooding along Crystal Springs Creek was first noticed in the summer of 1997 (Chestnut, 1997; Dillin, 1997). The creek overtopped the banks and flowed into park and recreational areas, onto streets, and into basements of creekside properties. The cause of the flooding was increased discharge from springs and decreased capacity of the channel. Reductions in the channel capacity between 1996 and 1997 probably was a factor because the streamflow of Crystal Springs Creek was nearly as high in 1996 when no flooding was reported as it was in 1997 when flooding was reported (fig. 2). An assessment of the channel capacity, specifically the effect of aquatic growth or sediment in the stream channel was beyond the scope of this study. Removal of aquatic weeds in August 1997 (when the streamflow was still relatively high) lowered the level of Crystal Springs Creek in the Westmoreland Park area by about $1.5 \mathrm{ft}$, which caused a near-bankfull rather than an overbank condition (Sellwood Bee, 1997).

The cumulative impact of consecutive years of higherthan-average precipitation and the resulting increase in groundwater discharge was the primary factor contributing to the high flow of Crystal Springs Creek. Precipitation records indicate that Crystal Springs Creek probably did not have an increased streamflow such as recorded from 1996 to 1999 since the channel was modified in 1936, and possibly not since 1911. The near-record precipitation in WY 1996 
(54.7 in.) was followed by the highest annual precipitation on record in WY 1997 of 58.7 in. (Oregon Climate Service, 2007) (fig. 5) The 3-year moving average annual precipitation depicts the unprecedented surge in groundwater recharge and subsequent discharge, and the multiyear recession observed in the late 1990s. The 3-year moving average precipitation in WY 1997, 1998, and 1999 was several inches greater than any year after recordkeeping began. By WY 2000, the 3-year moving average annual precipitation was close to the longterm average, and flow on Crystal Springs Creek had receded as well.

The elevated level of Crystal Springs Creek in the Westmoreland Park area probably is not associated with the rise of local groundwater levels and instead is the result of increased discharge of the numerous springs upstream of the Westmoreland area. Comparison of the hydrographs for the shallow and deep wells at Westmoreland Park (fig. 11) indicates a consistent downward gradient (where the head in the deeper well is less than the head in the shallow well) in this area. The absence of fluctuation in level of Crystal Springs Creek in the Westmoreland Park area (compared to 1 to $3 \mathrm{ft}$ fluctuations in the shallow water table) and concurrent measurements along Crystal Springs Creek that showed little gain or loss indicates an absence of connection with the aquifer. A survey of measuring point elevations for the wells and along Crystal Springs Creek would help determine if the stream lies above the water table and is therefore disconnected from the groundwater system.

Low flow of Crystal Springs Creek in the Reed College area (map number 38) in July 2005 prompted curtailment of irrigation withdrawals. The low flow in this area was confirmed by streamflow measurements made in July, September, and October 2005 (fig. 2). The average of the three measurements made in 2005 was about $0.3 \mathrm{ft}^{3} / \mathrm{s}$, less than one-third of the flow measured in the previous 3 years, and less than 5 percent of the highest flow measured in 1997. The likely cause of decreased spring discharge was a decline in water levels and therefore groundwater storage of the aquifer upgradient of the springs. The monitoring well at Berkeley Park (map number 21), $0.8 \mathrm{mi}$ southeast of the streamflow measurement location at Reed College, indicated there was little or no recharge in 2005, in contrast to previous years (2002 through 2004) that indicated an annual fluctuation in response to precipitation (fig. 10). Although 2005 was not a particularly dry year, precipitation came late in the season. In this condition, recharge for a given amount of precipitation may be less because of increased losses to evapotranspiration and soil moisture storage.

\section{Use of Hydrologic Data to Predict Streamflow of Crystal Springs Creek}

Because flow in Crystal Springs Creek is predominantly from the springs, and the spring flow is related to groundwater levels, flow of Crystal Springs Creek can be predicted using groundwater levels. The high flows of Crystal Springs Creek from 1996 to 1999 were the result of the prolonged effect of consecutive years of high precipitation in 1996 and 1997. Precipitation in 2005 was decreased or fell later (fig. 11), contributing little to groundwater recharge, which may have led to unusually low flows that summer. The groundwater level in the terrace just east of the headwaters of Crystal Springs Creek, represented by the Berkeley Park well (map number 21), fluctuates in response to precipitation (recharge), which is reflected in the subsequent discharge to the creek from the springs.

The Berkeley Park well has a continuous water-level recorder providing a useful data record for comparison with the streamflow of Crystal Springs Creek. However, in order to describe the relation between the streamflow of Crystal Springs Creek and groundwater levels, an intermediate step was required to estimate what the groundwater level was in the Berkeley Park area before the well was drilled in 2001. The water level in the Berkeley Park well relates closely to a well nearby that has a longer record of periodic measurements (map number 22) (pl. 1; fig. 9; table 1). Concurrent water-level measurements at these two wells from 2001 to 2006 were used in a regression to estimate the water level at the Berkeley Park well from October 1998 through August 2000, the period prior to the installation of the well (fig. 12). The extent of the data and the linear regression is scaled in fig. 12 to show the extent of extrapolation. Further data collection at higher water levels than those collected during the period of study may provide a better understanding of this relation.

The flow of Crystal Springs Creek at the Reed College site and at the mouth of the creek can be predicted based on groundwater levels at the Berkeley Park well (fig. 13). The relation of water level in the Berkeley Park well and flow of Crystal Springs Creek is valid over the range of concurrent water-level measurements and estimates, and streamflow measurements. The water level in the well ranged from 92.3 to $103.9 \mathrm{ft}$. The streamflow of Crystal Springs Creek encompassed by this relation was from 0.2 to $5.9 \mathrm{ft}^{3} / \mathrm{s}$ and from 9.2 to $19.1 \mathrm{ft}^{3} / \mathrm{s}$ for the locations at Reed College and at the mouth of the creek, respectively. 


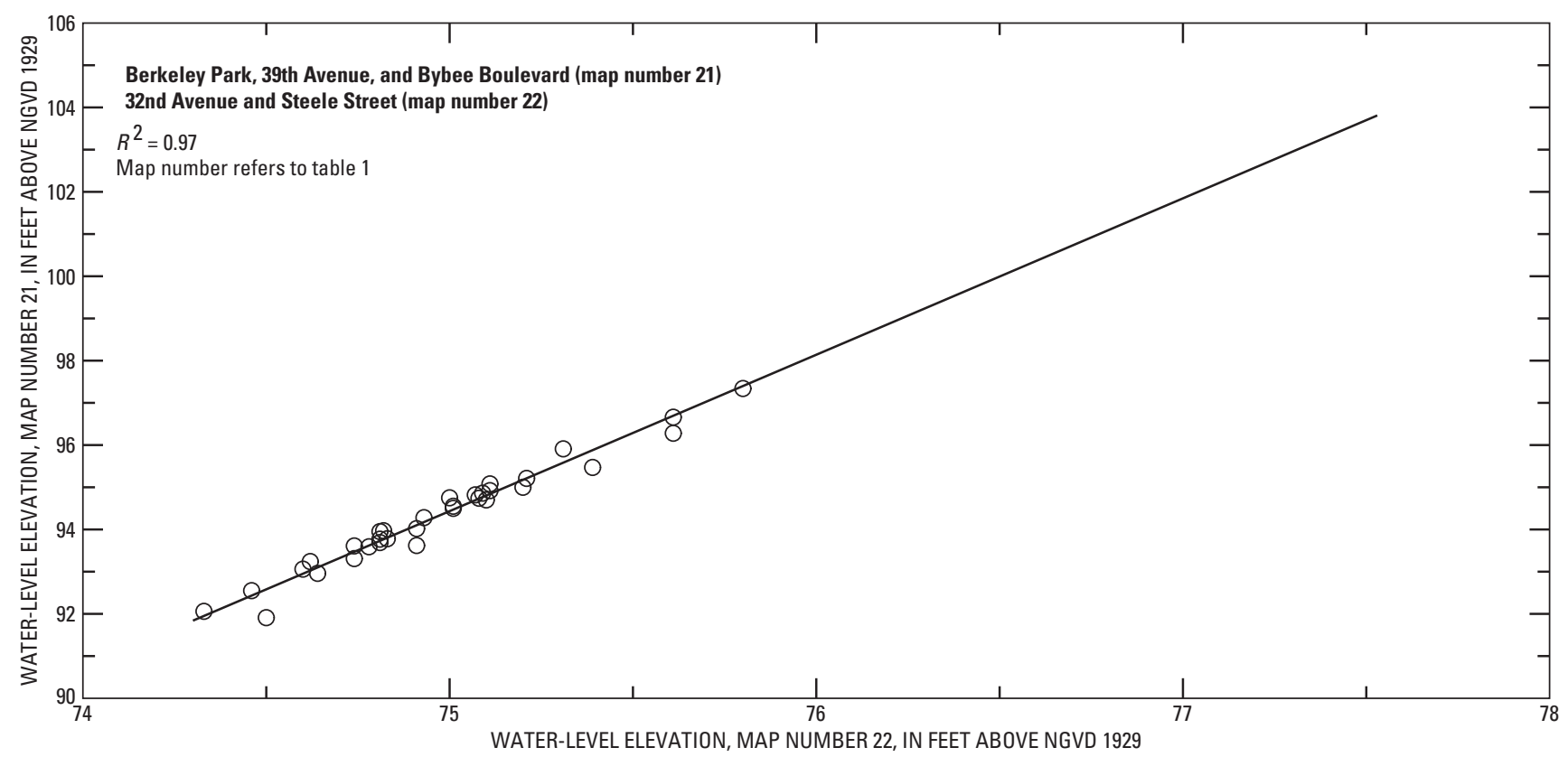

Figure 12. Relation between water level elevation in wells at Berkeley Park, and at 32nd Avenue and Steele Street, Portland, Oregon.

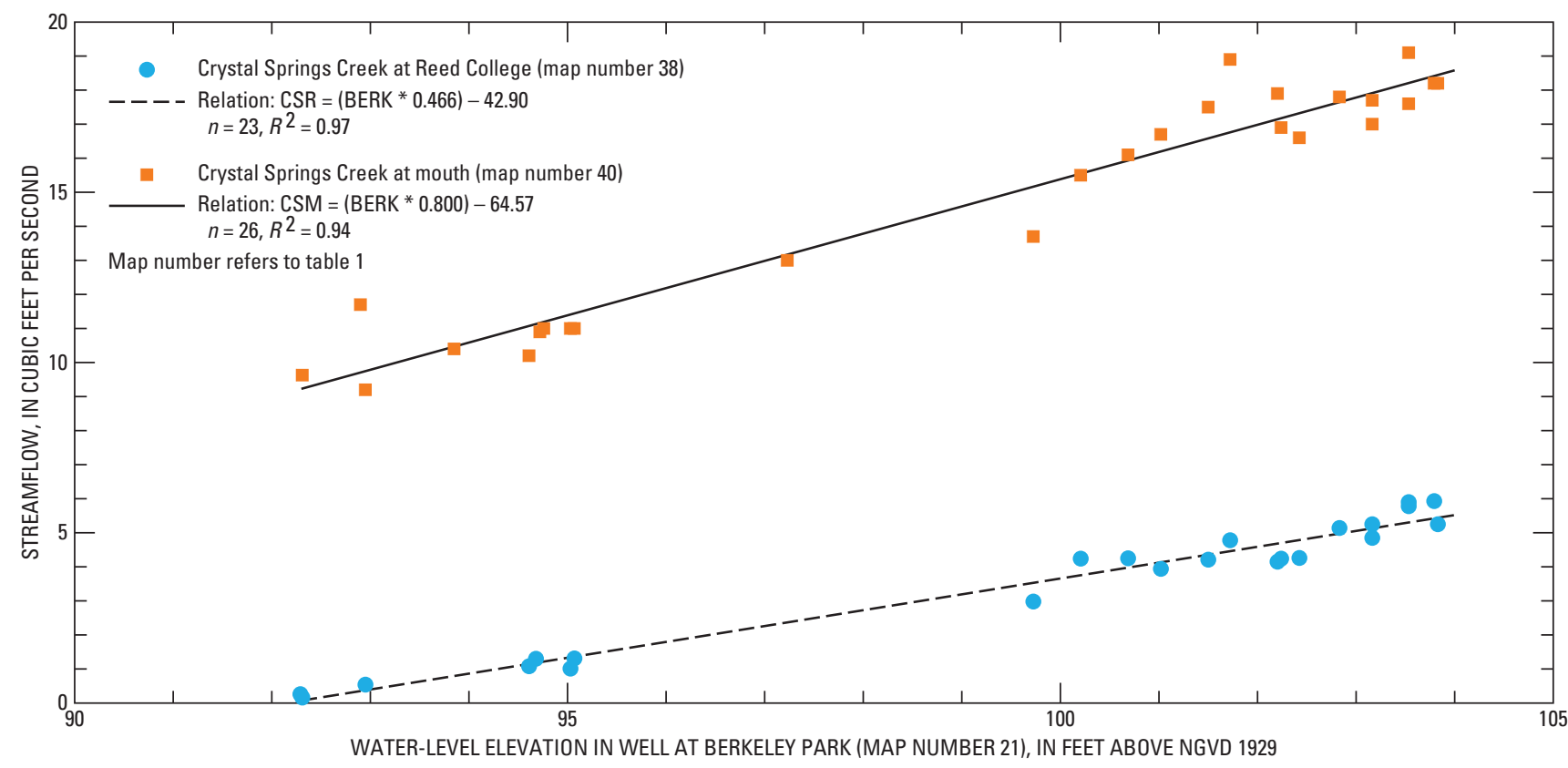

Figure 13. Relation between streamflow of Crystal Springs Creek at Reed College and mouth of Crystal Springs Creek at Portland, and water level elevation in the well at Berkeley Park, Portland, Oregon. 
As discussed previously, groundwater level in the area of the Crystal Springs Creek basin in Westmoreland Park is affected by the stream level of Johnson Creek and Willamette River. Although the summer stream level of Johnson Creek varies little from year to year, the Willamette River was particularly high in the summer of 1997, which was coincident with the high flow of Crystal Springs Creek. Because the wells in Westmoreland Park were not drilled until 2001, the relation of nearby river levels to groundwater level and streamflow in 1997 could not be explored. During June 1997, the stream level of the Willamette River was about $16 \mathrm{ft}$, about $6 \mathrm{ft}$ higher than during the same period from 1998 to 2006. Previous discussion referred to an absence of connection between Crystal Springs Creek in the Westmoreland Park area and the shallow aquifer. Continued monitoring of nearby stream levels and groundwater levels in wells in Westmoreland Park may provide further indications of stream-aquifer relations in this area.

\section{Flooding from High Groundwater Level-Holgate Lake}

Holgate Lake (map number 43) is an ephemeral lake in Southeast Portland near 136th Avenue and Holgate Boulevard (pl. 1). The origin of the lake and recurrent flooding and damage to nearby properties has been the subject of concern for local residents and municipal officials, prompting focused study in this area. Although the history of residential development of this area is uncertain, the first homes were probably built in the early 20th century. Until then, land use was primarily small farms. The lake is in a topographic depression in a residential area, and has flooded residences numerous times over the past several decades. Based on the present configuration of streets and residential development in the area, flooding begins whenever the lake level exceeds about $191 \mathrm{ft}$. Analysis of nearby groundwater level data and precipitation data has led to the conclusion that the occurrence of the lake is the result of groundwater flooding. Groundwater flooding begins in low-lying areas whenever the water table rises above the land surface (Jones and others, 2000). Precipitation and groundwater level data may be used to anticipate the extent of flooding in the low-lying area that has been designated as "Holgate Lake."

The first record of flooding in the area now known as Holgate Lake was in March 1949, indicating the lake had risen $6 \mathrm{ft}$ in 1 week, flooding several homes on the south side of the lake. The water-surface elevation of the lake was inferred from a photograph, indicating an elevation of between 190 and $195 \mathrm{ft}$. The cause was attributed to seepage from the surrounding slopes. The water level observed in 1949 was the highest since about 1943 (Gresham Outlook, 1949).
The next reports of flooding were in 1969. The elevation of the lake was about $199 \mathrm{ft}$, covered an area of about 50 acres (although the present interpretation of the flooded area is about 30 acres), and the western extent of the lake was near 128th Avenue. These observations were made in January 1969 and included a groundwater level measurement and reference to the land-surface elevation at a well near 122nd Avenue and Holgate Boulevard. The emergence of the lake was attributed to a rise in the water table (William S. Bartholomew, State of Oregon, written commun., 1969). A local newspaper attributed the flooding to unusually high water table and springs, following the heaviest precipitation since 1881. Flooding was reported by residents in 1943, 1948, 1956, and 1964 (Gresham Outlook, 1969).

Flooding from Holgate Lake began again in February 1996, lasting at least a month. The city of Portland pumped about $5 \mathrm{Mgal} / \mathrm{d}$ for a month from the lake to the sewer system, resulting in no decrease of the lake level. Flooding began again in December 1996, lasting at least until February 1997 (Oregonian, 1997). An aerial photograph of Holgate Lake in January 1997 was used to estimate the elevation of the lake at $195 \mathrm{ft}$ (Jennifer Antak, city of Portland, written commun., 2008).

Observations of the level of Holgate Lake by the USGS began in February 1999 and a water-level recorder was installed in March of that year (fig. 14). The recorder operated through 2000 and periodic water-level observations were made until May 2006. Except for the absence of the lake in 2001 and 2005, the typical pattern observed during the period of study was emergence of the lake in early winter each year and a return to a dry lakebed by midsummer.

The maximum lake level observed from WY 1999 to 2006 was $192.3 \mathrm{ft}$ on March 5, 1999, corresponding to a depth of about $9 \mathrm{ft}$ at the deepest part of the lake. The lake again extended over the street on its south side. The surface area of the lake was 1.2 acres on April 13, 1999 when the lake level was $190.3 \mathrm{ft}$ (about $2 \mathrm{ft}$ lower than the maximum level observed the previous month). The lake perimeter was defined using a Global Positioning System (GPS), and then mapping software was used to calculate the area. At the time of maximum level on March 5, 1999, the lake area was estimated to be about 3 acres.

Groundwater level monitoring near Holgate Lake began in July 1998 (fig. 14). The primary observation well (map number 9) is about $0.2 \mathrm{mi}$ southeast of the lake (table 1). A recorder (with telephone telemetry) provided real-time waterlevel data. In 1999, a hand-driven piezometer (map number 11) was temporarily placed in the lake bed to monitor the water level beneath the lake (fig. 14). In April 2000, a well was drilled on the western side of the lake (map number 10), replacing the piezometer, which was inaccessible much of each year. 


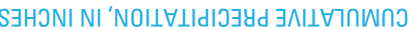

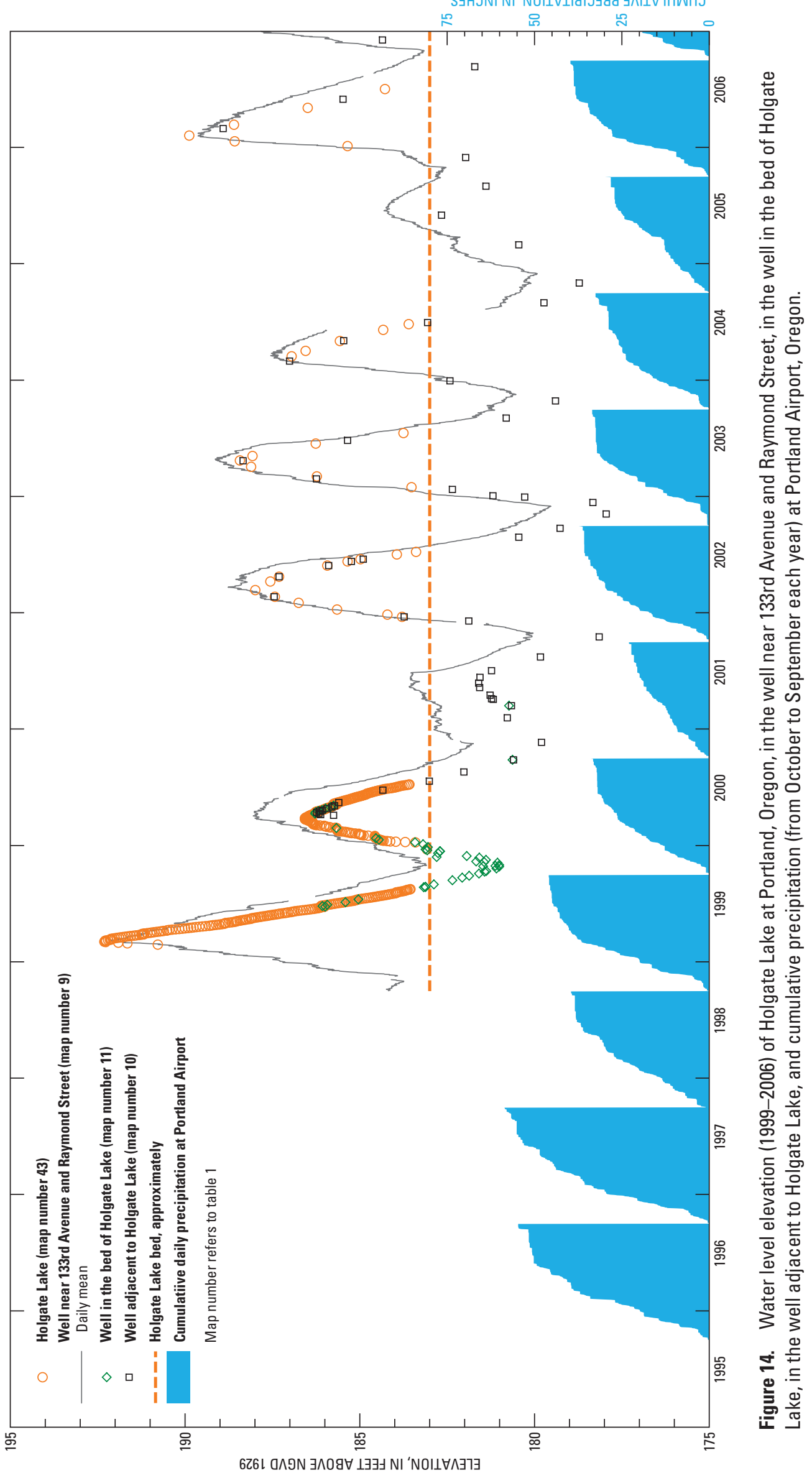


The fluctuation of water level in the primary observation well closely matches that of Holgate Lake (fig. 14). The lake level and the groundwater level in the wells in and on the western side of the lake agree closely. When water levels rise each winter, the lake level and groundwater level are similar. When groundwater and lake levels decline in spring and summer, the lake level declines more rapidly than the level in the primary observation well. By early winter, prior to the beginning of the recharge period, the groundwater level beneath the lakebed can be as much as $2 \mathrm{ft}$ lower than at the primary observation well.

\section{Use of Hydrologic Data to Anticipate Flooding from Holgate Lake}

Observations dating back to 1949 indicated that the cause of flooding of Holgate Lake was closely related to the water level in the shallow aquifer near the lake. This study confirms this hypothesis by comparison of lake level to water levels in nearby wells. The maximum level of Holgate Lake corresponds closely to the maximum groundwater level in the observation well (map number 9) nearby, and the groundwater level generally follows trends in cumulative precipitation each year (fig. 14). The primary observation well, equipped with telemetry, provides the water-table elevation to the public through the world-wide web at http://waterdata. usgs.gov/nwis/dv/?site no=452912122312801\&agency $\mathrm{cd}=$ USGS\&referred module $=\mathrm{Sw}$. The groundwater data from this well and precipitation data can be used in a general way to anticipate the emergence of the lake and the potential for flooding. Heavy precipitation, particularly in the autumn and early winter, leads to a rapid rise in groundwater levels, which in turn leads to emergence of Holgate Lake. Precipitation after about March and into the summer has less effect than early season precipitation, probably because of the increased evaporation, uptake by vegetation, and soil-moisture storage. For example, in WY 2001 and 2005, less than 20 in. of precipitation fell between October and March, resulting in no emergence of Holgate Lake. In 2005, substantial precipitation came later in the spring and summer, totaling about 30 in. for the water year; however, losses, probably because of evapotranspiration and soil-moisture uptake, reduced recharge to the shallow aquifer and resulted in no emergence of the lake.

The water level of Holgate Lake corresponds to precipitation amounts and timing, when, after satisfying a soilmoisture storage threshold, groundwater level rises several feet for each foot of precipitation (figs. 14 and $\underline{15}$ ). The annual groundwater level rise from WY 1999 to 2006 ranged from $1.8 \mathrm{ft}$ (2001) to $9.6 \mathrm{ft}$ (2003). Although the net rise observed in 2003 (but no flooding) was greater than observed in 1999 (and flooding present), the antecedent groundwater level prior to the autumn rainy period was $4.6 \mathrm{ft}$ higher in 1999 than in 2003. The higher antecedent groundwater level and higher precipitation in 1999 than in 2003 contributed to the 1999 flooding. Although no lake-level measurements were made at the beginning of WY 1999, the groundwater level at the site of the lake likely was near the lakebed, based on the assumption of relatively high groundwater levels in the area in the years following the high precipitation of 1996 and

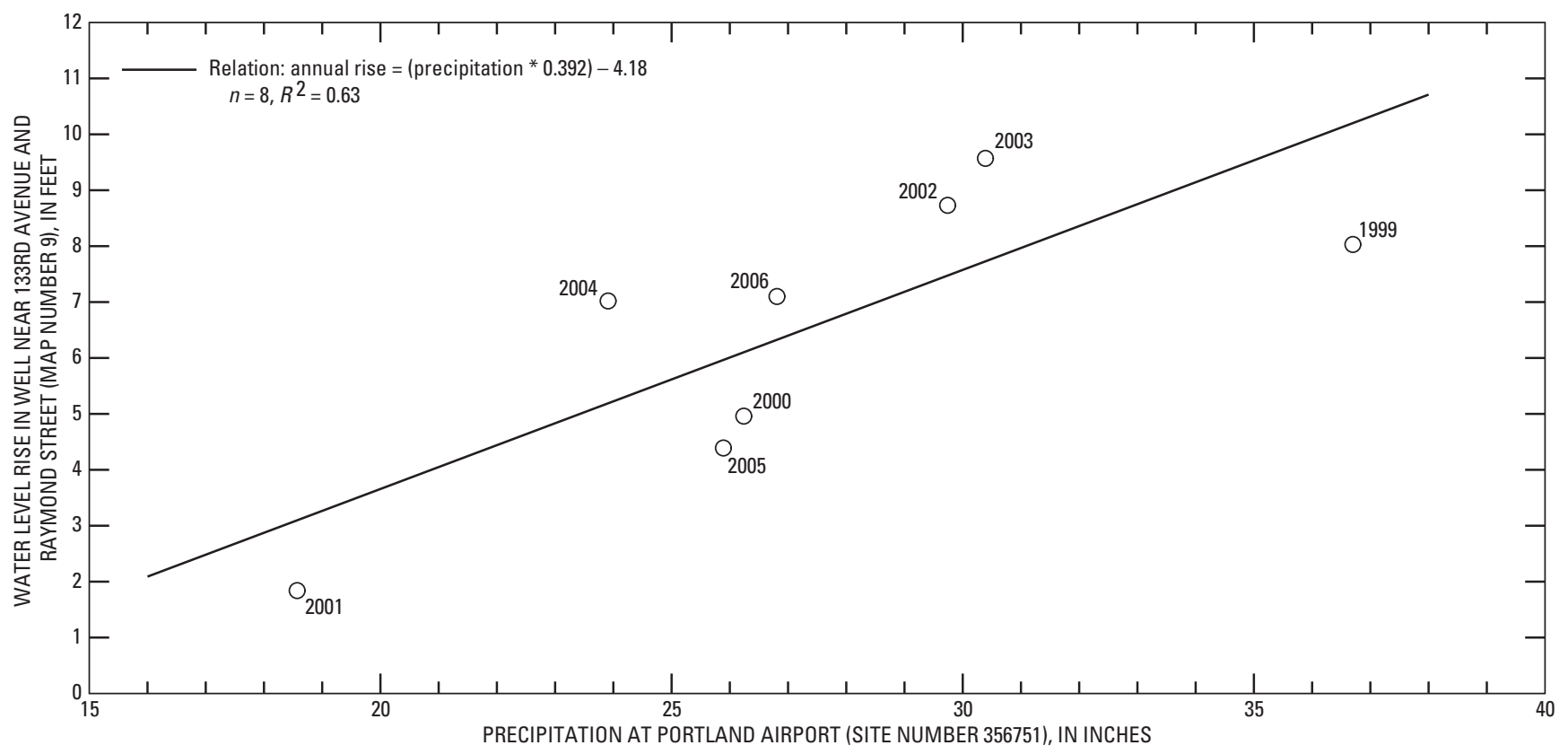

Figure 15. Relation between annual rise in water level in a well near 133rd Avenue and Raymond Street, Portland, Oregon, and cumulative precipitation at the Portland Airport, Oregon, from October 1 of each year to date of maximum water level in well, water years 1999-2006. 
1997. As indicated by the scatter of data points in figure 15, the response of groundwater level to precipitation is not predictable with certainty. The uncertainty may be a result of other factors not easily measured, including antecedent soil moisture, variations in porosity of the unsaturated zone at different depths, evapotranspiration, air temperature, precipitation timing and intensity, and basin-scale groundwater flow. Despite these uncertainties, the relation of water-level rise to precipitation may be useful to local residents and municipal agencies to assess flooding risks in the Holgate Lake area.

\section{Surface-Water Hydrology}

The following section is a discussion of the surface-water hydrology of the Johnson Creek basin as it relates to trends in annual flow, low flow, and high flow. Analyses of trends include comparisons of streamflow data on Johnson Creek and data from a streamflow measurement site in a nearby, undeveloped basin to ascertain the effects of development on streamflow. The Little Sandy River (map number 45) is not affected by regulation, and the long period of continuous streamflow record allows long-term comparison of the period of record of Johnson Creek at Sycamore (map number 30), where streamflow data collection began in 1940. The two basins additionally are similar in size, shape, and orientation and are only about $20 \mathrm{mi}$ apart. Land cover in the Little Sandy River basin primarily is forest, and periodic logging over the past century or more. However, hydrologic change because of land use and other human intervention generally has been less in the Little Sandy River basin than in the Johnson Creek basin.

Differences in both low and high flows are discussed in the sections below. The key differences are likely because of differences in elevation and precipitation. The elevation of the Little Sandy River basin is from about 700 to 4,300 ft, compared to 50 to 1,100 ft in the Johnson Creek basin. These differences result in lower temperature, more snow, and a more attenuated summer flow recession in the Little Sandy River compared to Johnson Creek. Average precipitation in the Little Sandy basin is 106 in./yr compared to $59 \mathrm{in}$./yr for the Johnson Creek basin at the Sycamore site, based on PRISM data from 1971 to 2000 (PRISM Group, 2007). In all, these differences result in more than triple the flow per unit area of the Little Sandy River compared to Johnson Creek.

\section{Annual Flow}

The factors controlling streamflow of Johnson Creek on an annual time scale are the distribution of precipitation and groundwater discharge and routing of runoff from the natural and human-modified landscape. More rain falls in the southern and eastern areas of the basin, coincident with increases in elevation. Precipitation, once on the landscape, can follow several pathways, where it can be delivered rapidly to the stream, or where it may enter the groundwater flow system as recharge and eventually discharge to the stream or out of the basin. Alterations in the form of roads, ditches, drywells, municipal sewer systems, and agriculture have an effect on the distribution of runoff; however, many of these changes may have predated collection of streamflow data in the Johnson Creek basin.

\section{Spatial Trends}

Spatial trends in annual flow were analyzed using streamflow and precipitation data from WY 1999 to 2006. The streamflow data used in this analysis are from Johnson Creek at Gresham (map number 26), Sycamore (in Portland) (map number 30), and Milwaukie (map number 41), and from measured flows of Crystal Springs Creek (map number 40). Comparisons were made of the flow at each site, of the inferred inflow between sites, and of flows compared to precipitation. Streamflow per unit area is greatest in the eastern area of the basin upstream of the Gresham site. This pattern of runoff is a result of three factors: (1) precipitation is greater in the upland areas because of the topography; (2) the less permeable, fine-grained soils and the relatively steep topography of the upland areas favor rapid runoff to the stream; (3) part of precipitation enters the combined sewer system in the western, more urban areas of the basin. Although Johnson Creek downstream of the Gresham site receives less runoff than would be expected in per unit area, focused groundwater discharge in some areas yields relatively high base flow. This high base flow is evident in Crystal Springs Creek, which features large flows compared to its relatively small surface-water contributing area.

Although spatial comparison of streamflow in per-unitarea generally is useful, this measurement poses challenges because of the coupled nature of the groundwater and surface-water flow systems, and human causes. Streamflow at a given location on Johnson Creek is the result of surface runoff and the net discharge from the groundwater flow system. The surface-water contributing area is a relatively static feature based on the topography. In an urban setting, the flow divides defining the contributing area can be altered by the configuration of street drains and other development. The groundwater contributing area, although it loosely mimics the topography, also is affected by groundwater flow direction (which varies with depth), and the hydraulic head in aquifers. Human-caused alterations additionally are in the "plumbing" of the drainage basin, such as expedited delivery of precipitation to the stream in agricultural areas by tile drains (reducing potential groundwater recharge), diversion of storm runoff to drywells in urban areas (reducing surface runoff to the stream), and diversion of storm runoff to the combined sewer system that discharges out of the basin. 
Annual mean streamflow increased from the Gresham to the Sycamore to the Milwaukie sites based on streamflow records from WY 1999 to 2006. The average streamflow of Johnson Creek from Gresham to Sycamore increased by 54 percent (from 28.7 to $44.2 \mathrm{ft}^{3} / \mathrm{s}$ ), and an additional 53 percent (to $67.8 \mathrm{ft}^{3} / \mathrm{s}$ ) from Sycamore to Milwaukie. About one-half of the increase in streamflow between the Sycamore and Milwaukie sites is from Crystal Springs Creek.

The streamflow in the three areas of the Johnson Creek basin was represented in per-unit-area. Streamflow in the upper basin is represented by the Gresham site. Streamflow in the middle basin is represented by the difference in streamflow between the Gresham and Sycamore sites. The lower basin is represented by the difference in streamflow between the Sycamore and Milwaukie sites. Dividing the average streamflow by the drainage basin area to derive a streamflow per-unit-area value enables comparison of different size areas of the drainage basin, and expression of streamflow per unit area in inches enables comparison to precipitation. The upper basin contributes more streamflow to Johnson Creek in per unit area than does either the middle or lower basins. The average streamflow (WY 1999-2006) of the upper basin was $25.3 \mathrm{in}$. compared to 18.5 and $12.1 \mathrm{in}$. in the middle and lower basin, respectively.

Estimates were made of precipitation falling on each area of the Johnson Creek basin to relate precipitation to streamflow in the area. Precipitation was estimated by determining the ratio between the PRISM-derived precipitation at the Portland Airport and of the upper, middle, and lower areas of the basin (PRISM Group, 2007). These ratios were applied to the measured precipitation at the Portland Airport from WY 1999 to 2006 (Oregon Climate Service, 2007). Streamflow as a fraction of precipitation decreases from 45 percent in the upper basin to 37 and 28 percent in the middle and lower basin, respectively.

The differences in the delivery of precipitation to the stream are a result of geomorphic settings and human causes. The upper area of the basin consists of moderate to steep terrain and fine sediments. These factors favor runoff from the land surface. A dense network of roads, ditches, and farm fields generally direct runoff away from the land surface and toward tributaries or the mainstem Johnson Creek. Compared to the upper basin, the lower basin generally is lower relief. Stream channel development, particularly on the north side of the basin is minimal because of the low relief and coarsegrained permeable Missoula Flood deposits. The present and predevelopment landscape feature minimal stream channel development. This area was shaped by deposits from catastrophic Columbia River floods, leaving a relatively flat and highly permeable landscape. Maps made by the General Land Office between 1852 and 1855 provided detailed descriptions of natural-resource features, and indicated few streams in the northern area of the basin (University of Oregon, 2006). Although the lower area of the Johnson
Creek basin primarily is a dense urban grid, runoff from streets, rooftops, and other impervious surfaces to the creek is curtailed through interception by the combined sewer system and drywells. The middle basin integrates features of the upper and lower basins, representing a mix of upper-basin and lower-basin characteristics, resulting in moderated streamflow relative to precipitation.

\section{Temporal Trends}

Temporal trends in annual flow in the Johnson Creek basin were identified through analysis of streamflow and precipitation data. The 66 years of record (WY 1941-2006) at the Sycamore site (map number 30) indicate long-term trends that are a response primarily to variation in precipitation. The cumulative departure from annual mean values is shown in fig. 16 for the periods of record of streamflow of Johnson Creek at Sycamore and at Milwaukie (map number 41), and of annual total precipitation at the Portland Airport. Annual mean streamflow of Johnson Creek at Sycamore, from WY 1941 to 2006 ranged from $15.6 \mathrm{ft}^{3} / \mathrm{s}$ (WY 1977) to $91.7 \mathrm{ft}^{3} / \mathrm{s}$ (WY 1997). Decade-scale dry cycles (such as from 1956 to 1967 and from 1984 to 1994) were accompanied by decreased annual mean streamflow. The relatively short period of record for Johnson Creek at Milwaukie tracks the end of a dry cycle in about WY 1994, follows the relatively wet years of WY 1995-1999, and again includes a drying trend from WY 2000 to 2005.

Temporal trends were tested in streamflow of Johnson Creek at Sycamore as a fraction of precipitation from WY 1941 to 2006 using the Kendall's tau correlation statistic. In this way, although precipitation varied over time, trends in the delivery of that precipitation to the stream on an annual scale were assessed. The null hypothesis is that the ratio of annual streamflow to precipitation is constant over time. A plot of the ratio of annual mean streamflow to precipitation over time indicated no visual trend and was substantiated by the Kendall tau value of -0.083 (a slight decreasing trend), and a p-value of 0.32, indicating that this trend was not statistically significant. The generally close relation of annual mean streamflow of Johnson Creek at Sycamore from WY 1941 to 2006 compared to annual total precipitation indicates that little has changed on an annual scale in the response of streamflow to precipitation.

\section{Low Flow}

Analyses of low streamflow, in terms of spatial and temporal variability, are needed to understand the effects of past land-use practices and the potential effects of future activities. Low streamflow and warm stream temperature has the potential to negatively impact the beneficial uses of the stream by wildlife and people. 


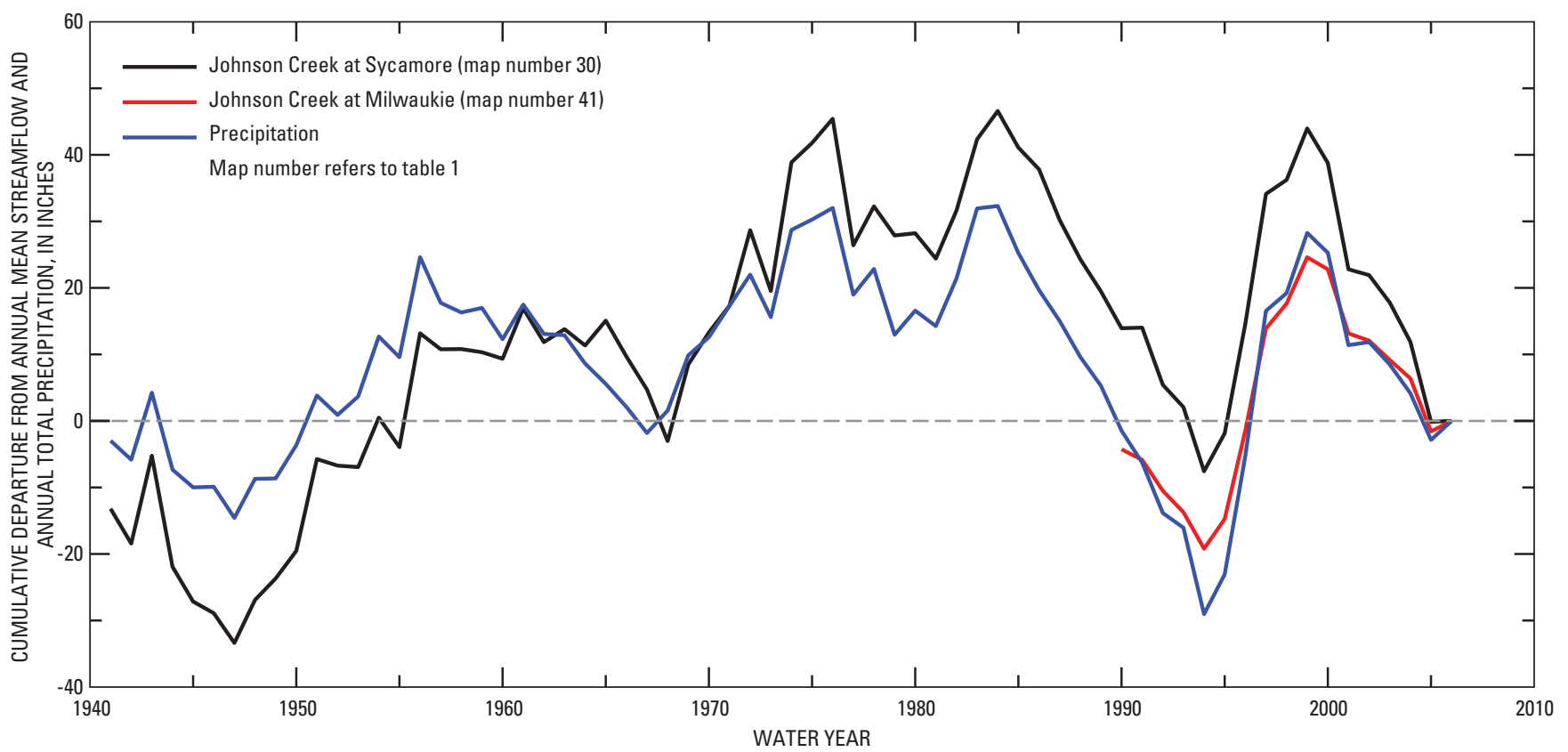

Figure 16. Cumulative departure from annual mean streamflow of Johnson Creek at Sycamore, Oregon, water years 1941-2006, Johnson Creek at Milwaukie, Oregon, water years 1990-2006, and annual total precipitation at the Portland Airport, Oregon (site number 356751), water years 1941-2006.

Factors that control the low-flow regime of Johnson Creek include the general topographic and geologic setting, land use, groundwater flow direction and discharge, climate, and water use. The low flow period typically is in the late summer. In this report, discussion of the groundwater flow system preceded discussion of streamflow, and in particular, low flow, because groundwater is the primary source of streamflow during the dry summer period. An understanding of low flow was derived in part from analysis of seepage measurements and low-flow characteristics at the streamflow sites on Johnson Creek. This analysis adds to the previous discussion, including analysis of streamflow data on Johnson Creek since 1940, and possible human-induced changes that may have exacerbated low flows in some years. The data used for this analysis are daily mean streamflow of Johnson Creek and Little Sandy River, streamflow measurements, and precipitation.

\section{Spatial Trends}

Low flow varies considerably across the Johnson Creek basin because of differences in groundwater discharge. Although precipitation is the initial source of streamflow, rainfall during the summer is minimal. The minimal rain in summer mostly is intercepted by the dry soils. Because of relatively high temperatures and active plant growth, water on the land surface and the vegetated canopy rapidly evaporates or transpires. Flow-duration curves were used in the analysis of spatial trends in low flow. High flows are exceeded only a small fraction of the time, whereas low flows are exceeded most of the time. Differences in the lower end of the flowduration curve indicate differences in flow characteristics related to the presence or absence of groundwater discharge to the stream.

Flow-duration analyses were based on daily mean streamflow from WY 1999 to 2006 at the streamflow sites in Gresham, Sycamore, and Milwaukie (map numbers 26, 30, and 41). The flow-duration curves representing the intervening areas were determined by subtracting the daily mean flow at the upstream site from that of the downstream site, which yielded the daily mean contribution of flow from the upper, middle, and lower areas of the basin. The flow associated with the percentage of time that was equaled or exceeded was divided by the size of the drainage basin area, which resulted in flow duration per square mile. Although the curves represent the range of flow duration, the focus of this analysis is the low-flow part (right side) of the flow-duration curve when a given flow is exceeded most of the time during the extreme low flow period.

The flow-duration curves shown in figure 17 illustrate the low flow characteristics in the three areas of the Johnson Creek basin. Notable characteristics of the low-flow end of the flow duration curves are the relative similarity of the curves for upper and middle areas of the basin and the distinct contrast with the curve for the lower area of the basin. The low-flow segment of the flow duration curves for the upper 
and middle areas of the basin are typical of streams that receive little groundwater discharge and that have rapidly decreasing streamflow during seasons of low precipitation. The lower basin, in contrast, features a sustained flow, particularly at flow duration greater than 60 percent, which is a result of groundwater discharge through springs in the lower area of the Johnson Creek basin. Although the broad, relatively low-relief northern area of the basin downstream of Sycamore contributes minimal flow, spring and seepage discharge to Johnson Creek downstream of RM 5.5 sustains summer flows. For example, at 90 percent flow duration, although the streamflow of the upper and middle areas of the basin is about $0.07\left(\mathrm{ft}^{3} / \mathrm{s}\right) / \mathrm{mi}^{2}$, streamflow in the lower area of the basin is $0.4\left(\mathrm{ft}^{3} / \mathrm{s}\right) / \mathrm{mi}^{2}$.

\section{Temporal Trends}

Temporal treads in low flow in the Johnson Creek basin from WY 1941 to 2006 were determined from analysis of daily mean streamflow data. These analyses include comparison of annual 7-day and 30-day minimum streamflow each year, comparison of flow-duration characteristics and base-flow separation. Although summer and annual precipitation have an effect on minimum flows each year, water use may have a greater effect during some years. A water-use assessment was not part of the study, so the effect of water use was inferred from the absence of correlation between low flow of Johnson Creek and low flow of Little Sandy River.

Annual 7-day and 30-day minimum streamflow statistics were computed for sites on Johnson Creek and on Little Sandy River. Most of the low flows of Johnson Creek extended past the water-year boundary (September 30 of each year), so the period of analysis for annual minimum flow was the low-flow season from May through October of each calendar year. The annual 7-day minimum flow of Johnson Creek at Sycamore (map number 30), from 1941 to 2006 ranged from about 0.1 to $2 \mathrm{ft}^{3} / \mathrm{s}$, and the annual 30-day minimum flow ranged from about 0.2 to $3 \mathrm{ft}^{3} / \mathrm{s}$ (fig. 18). Sustained high annual precipitation, characterized by the 3-year moving average precipitation from WY 1997 to 1999 (fig. 5) and resulting groundwater discharge to Johnson Creek, was the apparent cause of consistently elevated minimum flows during those years. Other years of particularly high (or low) 7-day or 30-day minimum flows did not appear to be as closely related to extremes in annual precipitation.

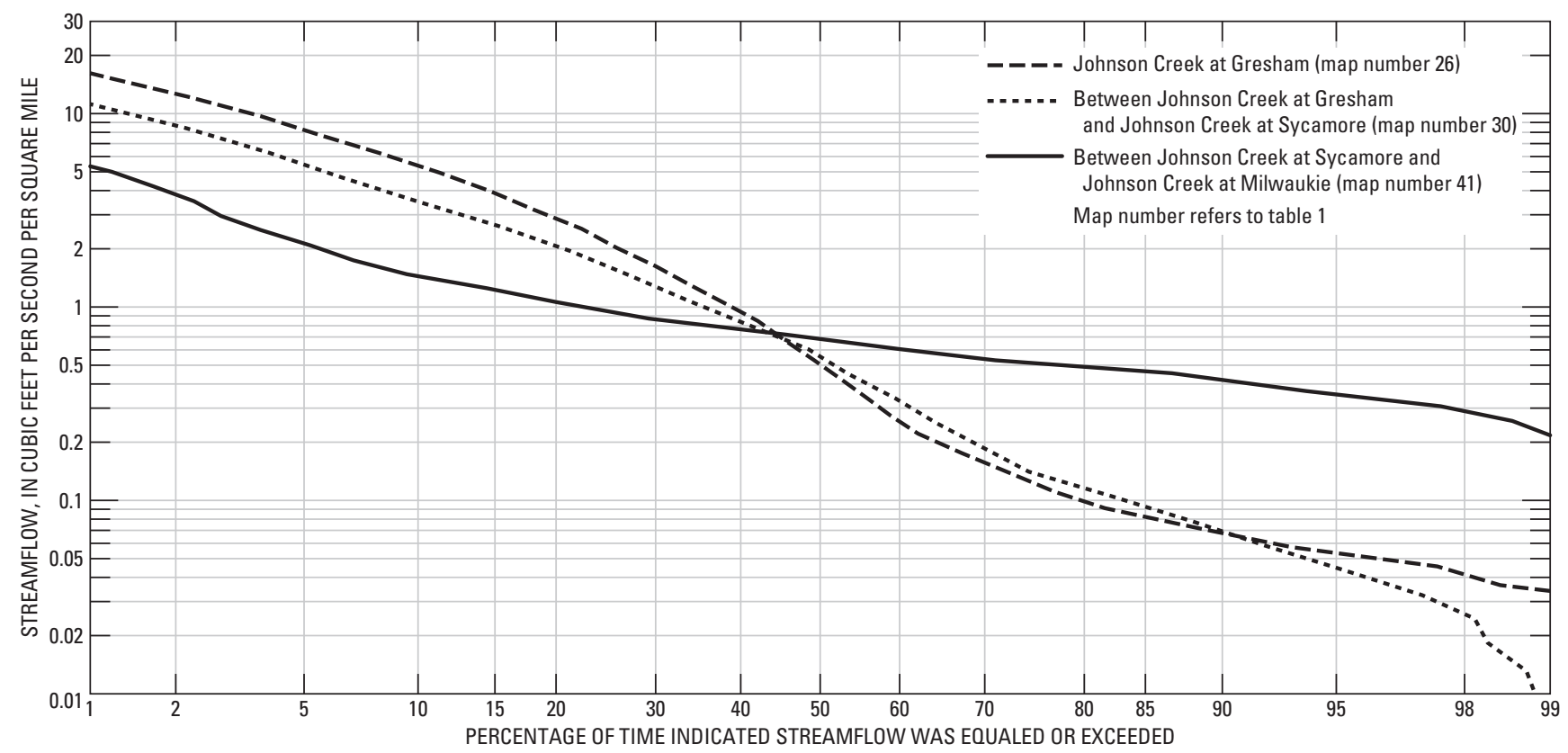

Figure 17. Flow duration curves of the upper area of Johnson Creek basin at Gresham, Oregon, of the middle basin between Johnson Creek at Gresham and Johnson Creek at Sycamore, Oregon, and of the lower basin between Johnson Creek at Sycamore and Johnson Creek at Milwaukie, Oregon, water years 1999-2006. 
During the period from 1955 to 1977, the annual 7-day and 30-day minimum flows of Johnson Creek at Sycamore each year were, on average, about one-half the long-term mean values for annual 7-day and 30-day minimum flows. These sustained low flows occurred despite some large values of annual precipitation (1956 and 1974) and a general increasing trend in annual total precipitation from about 1948 through 1956 and again from about 1969 through 1976 (fig. 5). Annual 7-day and 30-day low flows of Little Sandy
River (map number 45) did not indicate decreased summer flows during this period and actually were slightly greater compared to the period from 1941 to 2006. A potential cause for the particularly low streamflow of Johnson Creek during the 1955 through 1977 period is increased water use either from instream pumping or groundwater withdrawal that captured groundwater that would otherwise have discharged to the creek. The close relation of the 7-day and 30-day minimum flows shows a long-lasting decrease in summer

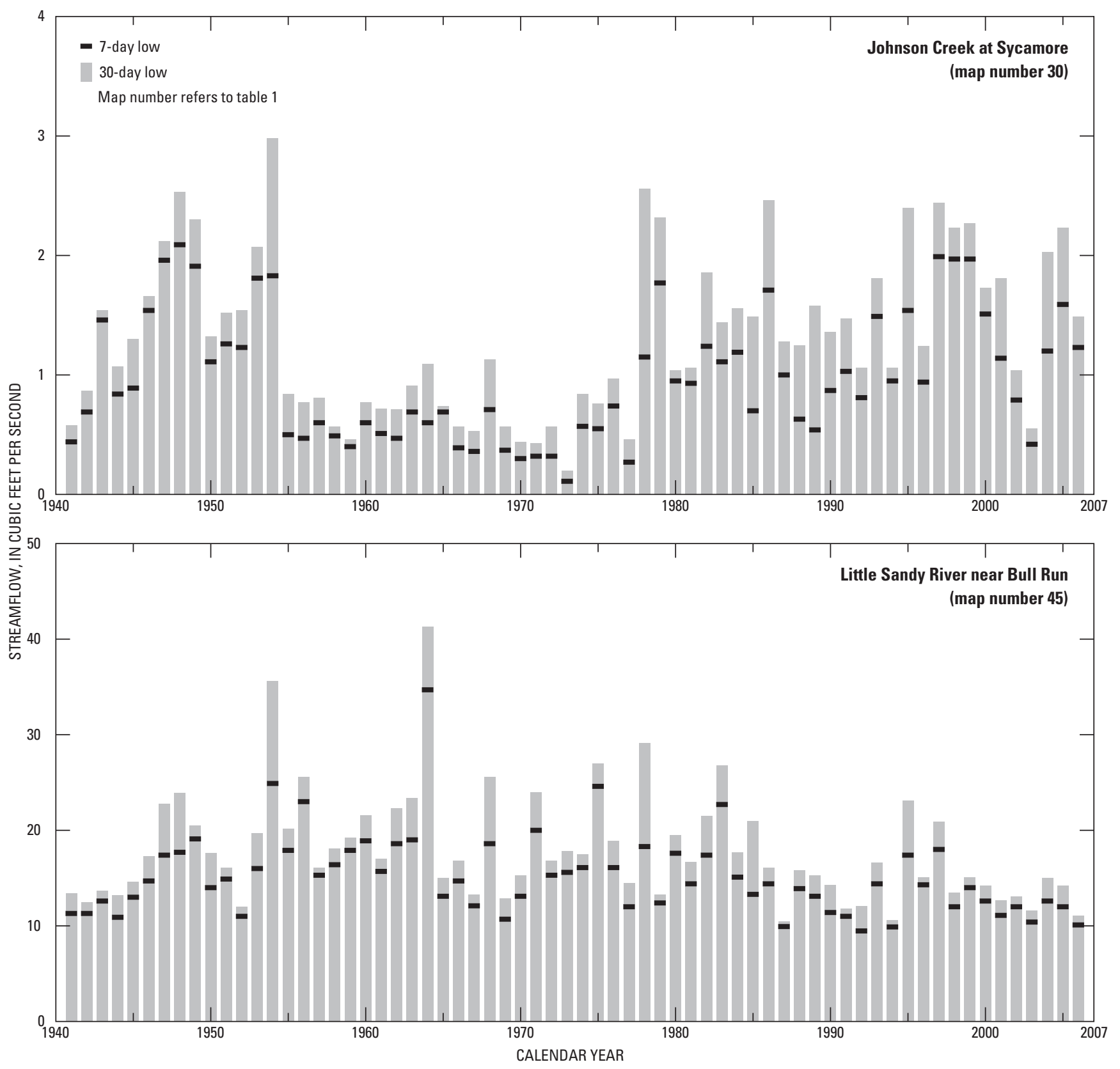

Figure 18. Consecutive 7-day and 30-day average low streamflow of Johnson Creek at Sycamore, Oregon, and of Little Sandy River near Bull Run, Oregon. 
flows of Johnson Creek during this period. After 1977, the 7-day and 30-day low flows generally increased in Johnson Creek indicating perhaps that the period of increased water use had ended.

Temporal trends in low flows also were assessed using flow-duration analyses. The period of record of Johnson Creek at Sycamore (map number 30) was divided into three segments of 22 years each, thus providing flow duration for the WY 1941-1962 (early), WY 1963-1984 (middle), and WY 1985-2006 (later) periods (fig. 19). The result of the flow duration analysis is consistent with that of annual minimum flows. The lower part (right side, low flow) of each duration curve is the focus for this analysis. Low flows, for example at 90 percent flow duration, during the early period were greater than in the middle period. The cause for this difference in low flows is likely the extreme low flows in the summers of 1955-77 (representing much of the middle period) as identified in the annual 7-day and 30-day minimum flow analyses (fig. 18). The later period indicates the greatest low flows of the three periods analyzed. A comparison of the extremes represented by the middle period and later period flow-duration curves shows that daily mean flow 90 percent of the time has increased from 0.9 to $1.7 \mathrm{ft}^{3} / \mathrm{s}$.

The base-flow component of streamflow may be affected by changes in the drainage basin over time. Changes typically associated with urbanization may reduce base flow because of reduced infiltration and diversion of storm runoff into the sewer system. The base-flow component of streamflow for
Johnson Creek at Sycamore for the period from 1941 to 2006 was determined using the program PART (Rutledge, 1998). Base flow ranged from about 45 to 70 percent of total flow. A trend test using Kendall's tau indicated a slight decreasing trend in percent base flow (a tau of -0.14); however, the p-value was 0.09 , indicating that the trend was not significant at the 0.05 level. The test was done on Little Sandy River for the same time period and also indicated no trend.

Trends identified in the low flow of Johnson Creek may relate to water use but are not necessarily associated with landuse changes characteristic of urbanization. The cumulative impact of urban development upstream from the Sycamore site from 1941 to 2006 has not affected the magnitude of low flows based on the overall absence of trend observed in the 7-day and 30-day low flow from 1941 to 2006, and the baseflow component of streamflow. This does not mean that the present low-flow condition is the same as prior to development in the basin, because much of the infrastructure was already in place prior to the beginning of streamflow data collection. These data do indicate, however, that changes in land use may have had less effect on low flow than water use, which may have had an increase around 1955 and subsequently decreased around 1977. As land uses change, primarily from agricultural and natural areas to a dense urban grid, particularly in upland areas, continued streamflow data collection and analyses are needed to document hydrologic response in the low-flow regime of Johnson Creek.

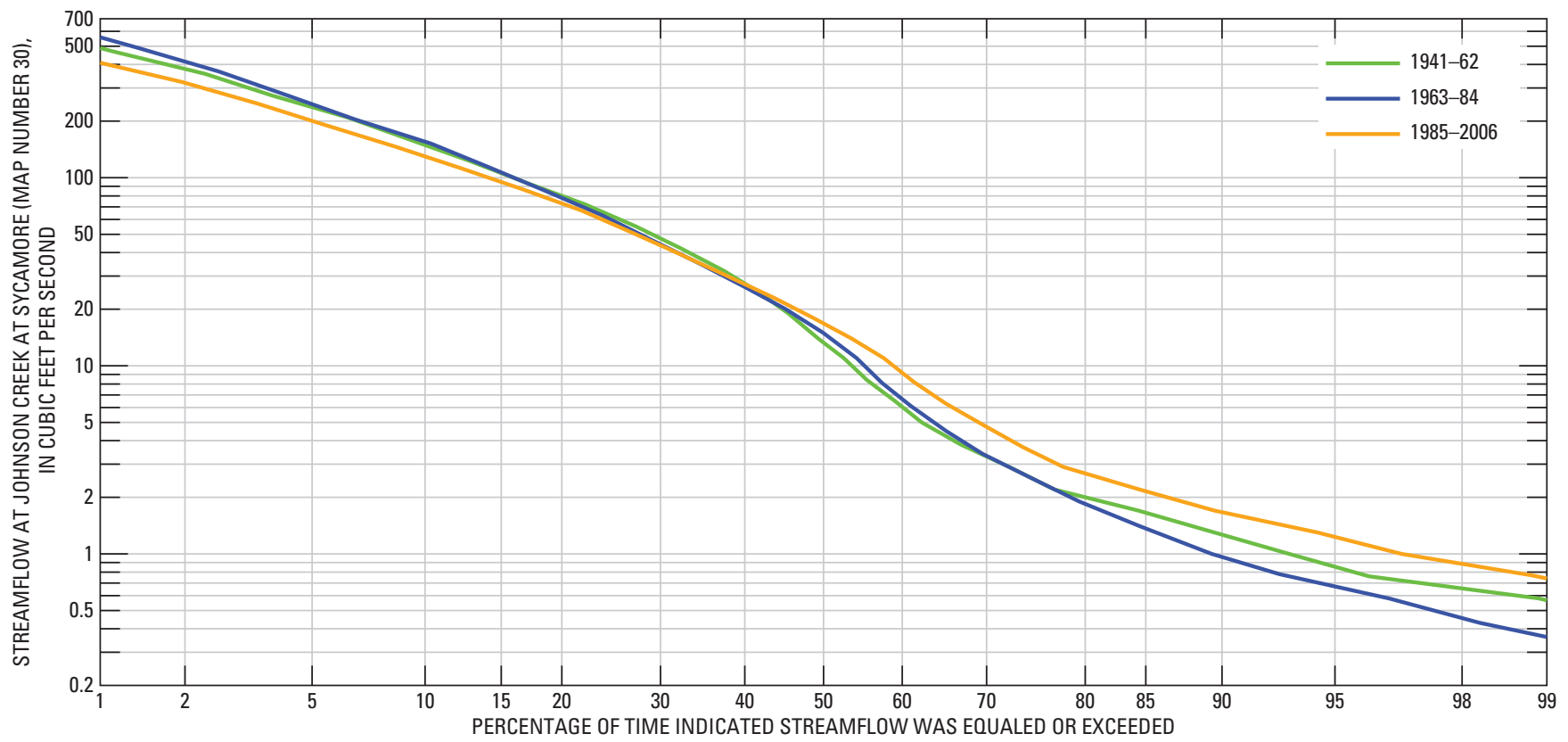

Figure 19. Flow duration curves based on water years 1941-1962 (early), water years 1963-1984 (middle), and water years 1985-2006 (later), Johnson Creek at Sycamore, Oregon. 


\section{High Flow}

Flooding of Johnson Creek likely was a concern when people began to inhabit areas near the creek. Prevention of flood damage was the primary incentive for the large-scale channel modification project that resulted in the present configuration of the lower $11 \mathrm{mi}$ of the creek. Johnson Creek floods as a result of intense rainfall, usually over a several day period, and sometimes melting snow adds to the flood. In contrast to annual and low flow on Johnson Creek, where the magnitude of flow is in part controlled by the groundwater system, the presence of high flow mostly is a response to runoff from the land surface. The degree of flooding typically is determined by precipitation intensity and antecedent soil moisture. Other factors that can contribute to spatial and temporal variability in high flow events are temperature, topography, soil type, vegetation, channel configuration, the network of roads, ditches, storm drains, sewer systems, and impervious surfaces. Changes in the frequency of flooding, particularly related to changes in land uses in the basin have been a topic of discussion for decades. The record of streamflow of Johnson Creek at Sycamore (map number 30) are relatively long, dating back to WY 1941. The Johnson Creek streamflow record at Sycamore and the shorter-term records at Milwaukie (map number 41; since WY 1990) and at Gresham (map number 26; since WY 1999) provide data for comparison and assessment of temporal trends in high flow across the basin.

Spatial and temporal trends in high flow of Johnson Creek were evaluated based on annual peak flow and daily mean flow. Stream level during high-flow conditions is often of primary interest. Flow is computed at each streamflow site and the stream level is related to a peak streamflow using a stage-discharge rating. Changes as a result of scour and fill in the stream channel, and natural and constructed features in and near the stream can affect the level at a given streamflow. Flood-frequency statistics were computed for the Johnson Creek at Sycamore and at Milwaukie sites. Daily mean streamflows were used for flow duration analysis at the Gresham, Sycamore, and Milwaukie sites, and comparisons of the fraction of days in a year that are greater than the annual mean streamflow were made at the Sycamore and Milwaukie sites.

\section{Spatial Trends}

Analyses of spatial trends in high flow in the Johnson Creek basin include comparison of peak flows and volumes, flood frequency, flow duration, and the fraction of daily mean flows that are greater than the annual mean streamflow. Better understanding derived from comparison of peak flows is compared to previous studies of the area.
The annual peak streamflow at the Milwaukie site can be either greater or less than at Sycamore, contrary to what may be expected because of a two-fold increase in basin area (table 3, fig. 20). The annual peak usually is on the same day, and only in WY 2001 (an extremely dry year) was the peak of the year at each site the result of a different storm. The difference in annual peak streamflow varied widely. The annual peak streamflow at the Milwaukie site was between 24 percent less (WY 1997) and 53 percent more (WY 2005) than at the Sycamore site. The average increase in peak flow from the Sycamore site to the Milwaukie site, based on peaks from WY 1990 to 2006, is 11 percent. The difference in peaks after WY 1997 may have increased (table 3); however, the record of concurrent peaks is lacking. Uncertainties in the stage-discharge rating at the Milwaukie site (because of the relatively short period of record compared to the Sycamore site) additionally may affect the computation of peak flow.

The peak flow at each site is a function of the spatial and temporal distribution of precipitation and runoff characteristics of each area of the Johnson Creek basin. The timing and magnitude of precipitation (and subsequent runoff) in the area of the basin between the Sycamore and Milwaukie sites is not the same as for the area of the basin upstream of the Sycamore site because of the general east-west orientation of the basin; the tracking of storms, most of which is from west to east; and the generally greater precipitation in the areas of the basin at higher elevations. Depending on rainfall patterns and intensity, the response in flow at the Milwaukie site may be a single (and potentially larger) peak, an attenuated response, or peaks separated by several hours. Peaks at the Milwaukie site additionally may be attenuated by interception of precipitation in the relatively flat, permeable deposits on the northern side of the basin, and by interception by drywells and combined sewer systems.

The relation of peak streamflow to stream level is fairly consistent at Johnson Creek at Milwaukie; however, the level of the Willamette River in the Portland area can cause backwater conditions in the lower area of Johnson Creek, extending an undetermined distance upstream of the Milwaukie site. Backwater from the Willamette River seems to affect Johnson Creek at the Milwaukie site when the level of the Willamette River exceeds about $22 \mathrm{ft}$, which is recorded twice after records at the Milwaukie site began in WY 1990. On February 8, 1996, at the time of the peak level at the Milwaukie site, the level of the Willamette River at Portland (map number 44) was about $22 \mathrm{ft}$. Although the flow of Johnson Creek decreased following the peak, because of the relatively large size of the Willamette River basin, the Willamette River at Portland continued to rise, peaking at about $27.7 \mathrm{ft}$ on February 9. This rise of the Willamette River resulted in a rise in stream level of Johnson Creek of about 
Table 3. Annual peak streamflow and volume, Johnson Creek, Oregon, water years 1990-2006.

[Map numbers are shown in table 1. Percentage change and period of analysis: (a) not computed due to different storm event; (b) one or more daily mean streamflow estimated. A bbreviations: $\mathrm{ft}^{3} / \mathrm{s}$, cubic foot per second; $\mathrm{mi}^{2}$, square mile]

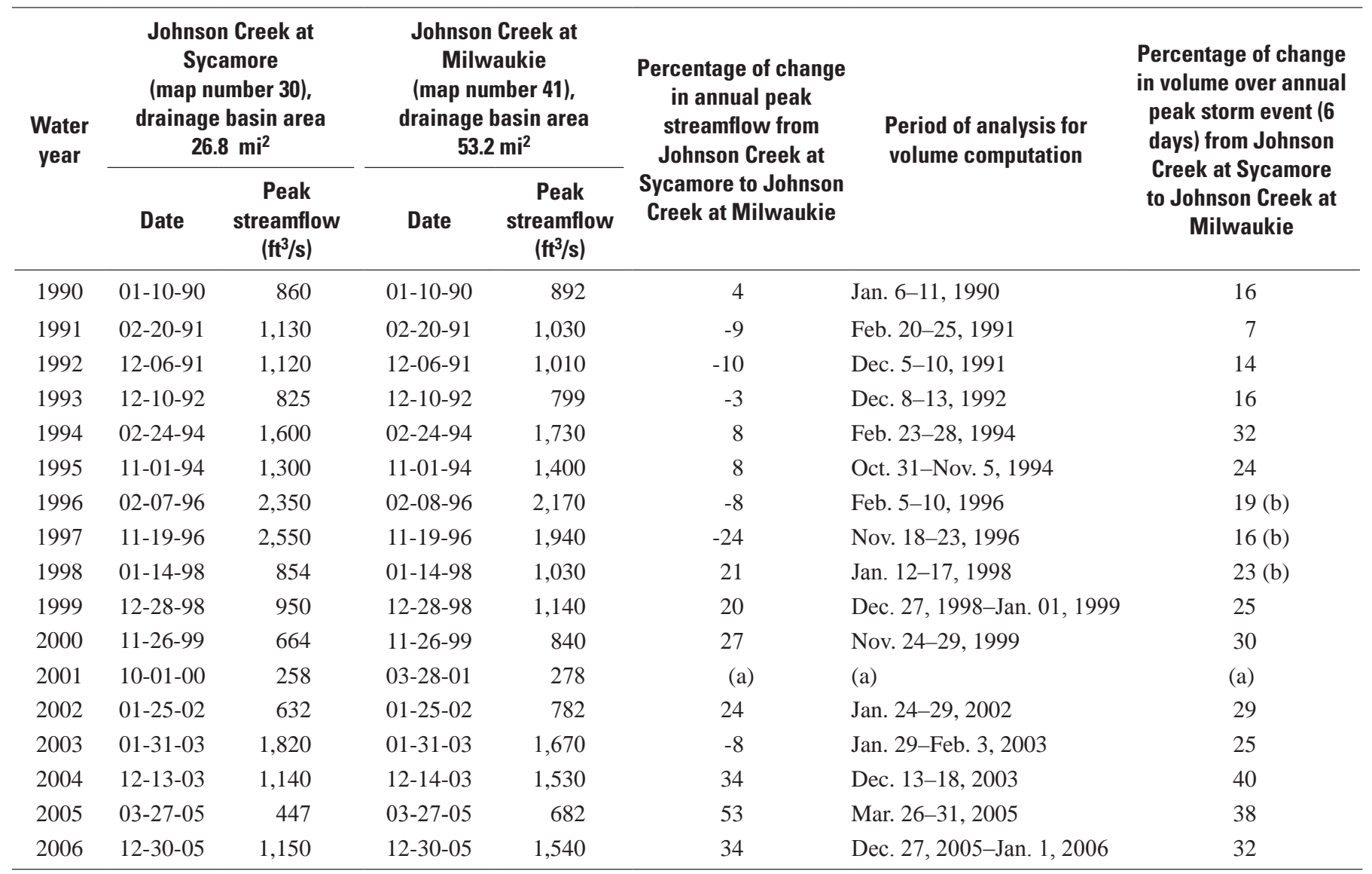

$4 \mathrm{ft}$, despite decreasing streamflow of Johnson Creek. The backwater condition at the Milwaukie site lasted for several days resulting in the flooding of nearby properties. More backwater at Johnson Creek at Milwaukie was recorded in January 1997 when the Willamette River at Portland peaked at about $23 \mathrm{ft}$ causing backwater at the Milwaukie site for about 2 days.

Although peak volume increases between the Sycamore and Milwaukie sites, the increases are not proportional to the increase in the size of the drainage basin area between the two sites. The peak volume each year was defined as the cumulative daily mean streamflow during the 6-day period surrounding the annual peak (table 3). The 6-day period was selected by visual inspection of the instantaneous streamflow hydrograph, beginning the day of increase in flow and extending several days past the day of peak flow. Antecedent flow was not taken into account in this analysis because it was relatively low (compared to the peak flow) and fairly similar at the two sites. The average increase in annual peak volume between the Sycamore and Milwaukie sites from 1990 to 2006 was 24 percent, and ranged from 7 to 40 percent. Factors contributing to the relatively small increase in runoff volume between the Sycamore and Milwaukie sites may be the increased infiltration through the permeable surficial deposits, capture of runoff from the urban area between the two sites, and subsequent transport of storm runoff either to drywells or to the combined sewer system.

Flood frequency statistics for Johnson Creek at Milwaukie based on annual peaks from 1990 to 2006 were compared to those for Johnson Creek at Sycamore for the same period (fig. 21, table 4). This analysis indicates that streamflows for recurrence intervals greater than about 10 years are greater at the Sycamore site than at the downstream site. The smaller values at the Milwaukie site may indicate that peak flows at the upstream site that are in excess of the channel capacity are temporarily stored on the floodplain and do not contribute to the peak flows at the Milwaukie site. Flood-frequency statistics for Johnson Creek 


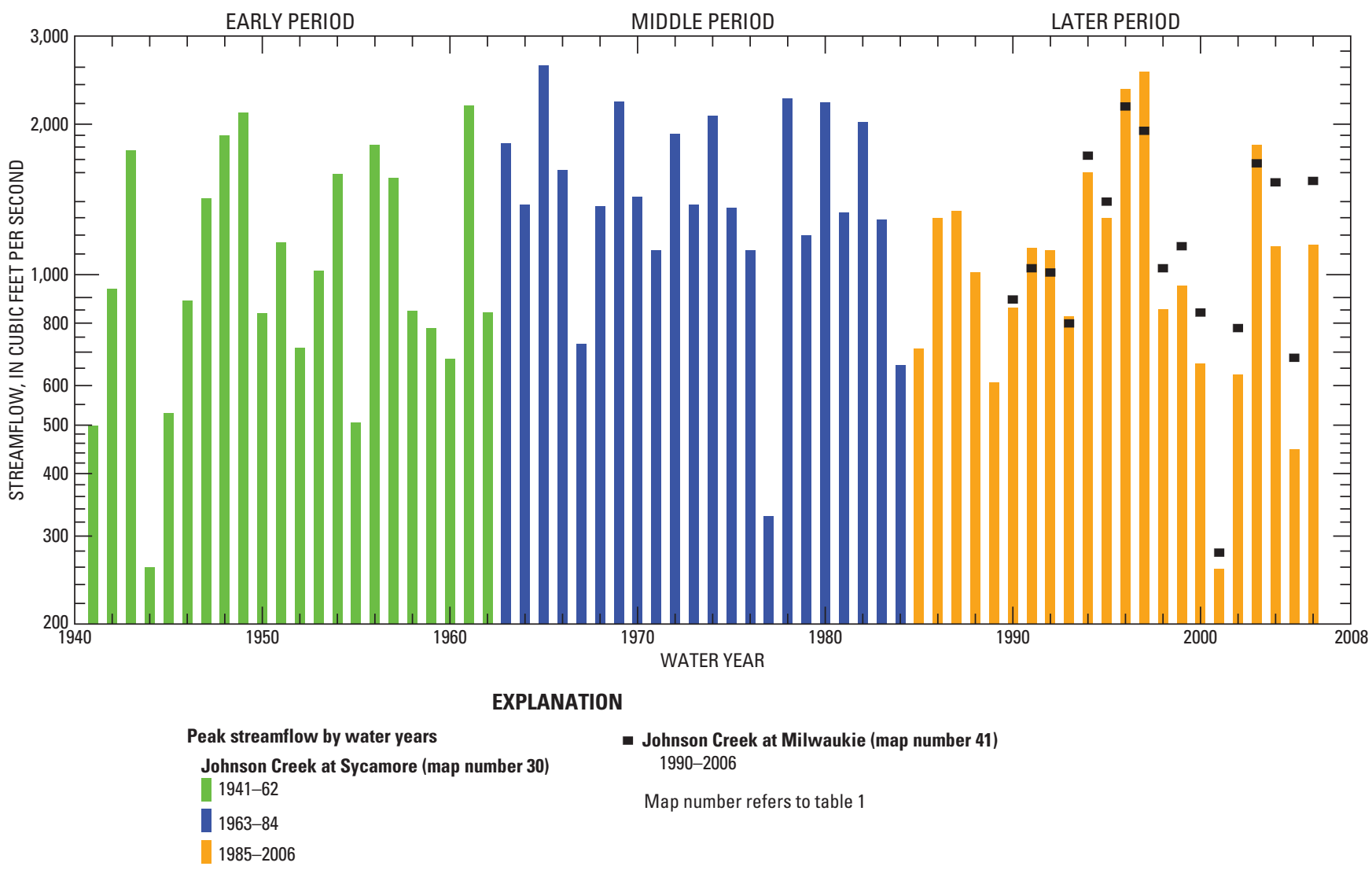

Figure 20. Annual peak streamflow of Johnson Creek at Sycamore, and Johnson Creek at Milwaukie, Oregon.

at the Sycamore site for the entire 1941-2006 period of record also are shown in figure 21 and table 4. Flood-frequency statistics generally are more reliable for longer periods of record, but the differences between the 1990-2006 period and the 1941-2006 period are slight for this site.

Similar to analyses of low-flow duration statistics, the high-flow part of the duration curve indicates differences in flow-duration characteristics of the upper, middle, and lower areas of the basin. At a flow duration of 5 percent (where daily mean streamflow is equaled or exceeded 5 percent of the time), as shown in figure 17, the area of the drainage basin upstream of the Gresham site contributes $8\left(\mathrm{ft}^{3} / \mathrm{s}\right) / \mathrm{mi}^{2}$, compared to $5\left(\mathrm{ft}^{3} / \mathrm{s}\right) / \mathrm{mi}^{2}$ between the Gresham and Sycamore sites and $2\left(\mathrm{ft}^{3} / \mathrm{s}\right) / \mathrm{mi}^{2}$ between the Sycamore and Milwaukie sites. When the contribution to high flow of the upper, middle, and lower areas of the basin are compared, differences generally are a result of decreased precipitation, gentler slopes, more permeable soils, and greater interception by drywells and combined sewer systems toward the west.

An assessment based on daily mean streamflow at the Sycamore and Milwaukie sites from 1990 to 2006 was made of the "flashiness" of the stream, which is the tendency of the streamflow to rise from a base-flow condition rapidly and decline rapidly. The indicator statistic is the percentage of days in a year where the daily mean streamflow is greater than the mean streamflow in that year. In a basin with rapid, short-duration, or "flashy" runoff, a smaller percentage of days exceed the mean streamflow for the year when compared to a basin in which streamflow rises and declines more slowly. Konrad and Booth (2002) and Chang (2006) showed that this statistic was an indicator of urbanization, affecting streams in Washington and in the Portland, Oregon, area (including Johnson Creek). The consequence of rapid changes in flow on a stream may be degradation of the stream channel, erosion, and disruption of biota in the stream. The mean flow of Johnson Creek at the Sycamore and Milwaukie sites was exceeded an average of 29 percent of the time. The same analysis was made of Little Sandy River (map number 45), where the mean streamflow was exceeded an average of 34 percent during the same period. These results are consistent with previous studies that showed the mean streamflow was exceeded a smaller fraction of the time in urban streams than in rural streams (Konrad and Booth, 2002). The similarity of this statistic at the Sycamore and Milwaukie sites primarily is because of the absence of storm-induced rapid runoff in the lower area of the basin. 
Table 4. Magnitude and probability of peak streamflow of Johnson Creek, Oregon.

[Map numbers are shown in table 1 . A bbreviations: $\mathrm{ft}^{3} / \mathrm{s}$, cubic foot per second; $n$, number of years]

\begin{tabular}{cccc}
\hline $\begin{array}{c}\text { Water } \\
\text { years }\end{array}$ & $\begin{array}{c}\text { Recurrence } \\
\text { interval } \\
\text { (years) }\end{array}$ & $\begin{array}{c}\text { Annual } \\
\text { exceedance } \\
\text { probability } \\
\text { (percent) }\end{array}$ & $\begin{array}{c}\text { Peak } \\
\text { streamflow } \\
\left(\mathbf{f t}^{\mathbf{3}} / \mathbf{s}\right)\end{array}$ \\
\hline \multicolumn{4}{c}{ Johnson Creek at Sycamore (map number 30) } \\
(systematic & $n=66$; historical & $n=0$; weighted skew $=0.448)$ \\
\hline $1941-2006$ & 1.25 & 80 & 717 \\
& 2 & 50 & 1,150 \\
& 5 & 20 & 1,750 \\
& 10 & 10 & 2,140 \\
& 25 & 4 & 2,590 \\
& 100 & 2 & 2,920 \\
\hline
\end{tabular}

Johnson Creek at Sycamore (map number 30)

(systematic $n=17$; historical $n=0$, weighted skew $=0.095$ )

\begin{tabular}{rrrr}
\hline $1990-2006$ & 1.25 & 80 & 693 \\
2 & 50 & 1,040 \\
5 & 20 & 1,580 \\
10 & 10 & 1,970 \\
25 & 4 & 2,510 \\
50 & 2 & 2,930 \\
& 100 & 1 & 3,380 \\
\hline
\end{tabular}

Johnson Creek at Milwaukie (map number 41)

(systematic $n=17$; historical $n=0$; weighted skew $=0.104$ )

\begin{tabular}{rrrr}
\hline $1990-2006$ & 1.25 & 80 & 840 \\
2 & 50 & 1,140 \\
5 & 20 & 1,570 \\
10 & 10 & 1,860 \\
25 & 4 & 2,240 \\
50 & 2 & 2,530 \\
100 & 1 & 2,820 \\
\hline
\end{tabular}

The relatively small change in flood-frequency of Johnson Creek at the Sycamore and Milwaukie sites, especially the decrease in flood flows for recurrence intervals greater than about 10 years, is not consistent with predictions of flood frequency from methods currently used in Oregon. Although the available flood prediction equations developed for use in Oregon (Cooper, 2005) are applicable only to rural streams in western Oregon and thus may not be reliable for urbanized basins such as the Johnson Creek basin, equations for use on urbanized streams in the Portland area were developed by Laenen (1980). Laenen's prediction equations, which included data from the Sycamore site on Johnson Creek, used basin drainage area and a basin-storage term as explanatory variables. The form of the prediction equations indicated that flood flows for a given recurrence interval increase with increasing size of the drainage basin area, but that flood flows for a given recurrence interval decrease with increasing basin storage. Results from the prediction equations developed by Laenen (1980) are particularly sensitive to estimated values of basin storage and basin storage is difficult to determine and perhaps not directly related to factors that may be affecting flood runoff in the lower area of the basin, such as increased storm runoff interception. Based on the available data and definitions provided by Laenen (1980), basin storage at the downstream Milwaukie site was not much different than basin storage at the upstream Sycamore location. Application of the prediction equations, using equal values for basin storage but considerably larger drainage basin size at Milwaukie than at Sycamore, yielded peak-flow estimates for the Milwaukie site that were about twice as large as those from the $\log$ Pearson 3 analysis of the measured peak streamflow.

As a result, the Laenen (1980) equations do not reliably account for the factors that affect flood-frequency statistics on Johnson Creek, although they may be reliable for prediction purposes on other urbanized streams in the Portland area.

\section{Temporal Trends}

Streamflow and water level at the Sycamore site (map number 30) were used in the analyses of temporal trends in high flow of Johnson Creek. High flows were characterized in terms of annual peaks, flow duration, and the fraction of daily mean flows that are greater than the annual mean streamflow.

A Kendall's tau test applied to the 66-year record of annual peak flows (fig. 20) indicated an absence of a temporal trend in annual peaks; the value of tau was -0.03 and the p-value was 0.70 . Although the basin has changed much between 1941 and 2006, those changes have not led to a trend toward higher or lower peak flows.

Because a concern during flooding is the stream level rather than streamflow, an analysis was made of the trend in annual peak stream level associated with each annual peak streamflow at the Sycamore site from WY 1941 to 2006. The stage-discharge rating curve in use in WY 2006 is shown in figure 22; points represent the annual peak stream level and streamflow in the early (WY 1941-62), middle (WY 196384), and later (WY 1985-2006) periods. Most peaks from the later period plot along this curve. Many peaks in the early and middle periods plot to the right of the curve (greater streamflow for a given stream level), indicating, in general, that the capacity of the stream channel to carry high flow was greater in the early and middle periods than in the later period.

The change in the relation of stream level to streamflow is from about 700 to $1,500 \mathrm{ft}^{3} / \mathrm{s}$, and amounts to a $1-\mathrm{ft}$ aggradation (filling) of the stream channel. At streamflow less than about $700 \mathrm{ft}^{3} / \mathrm{s}$, the peak stream level relative to streamflow is more variable than at higher flow, which is a 


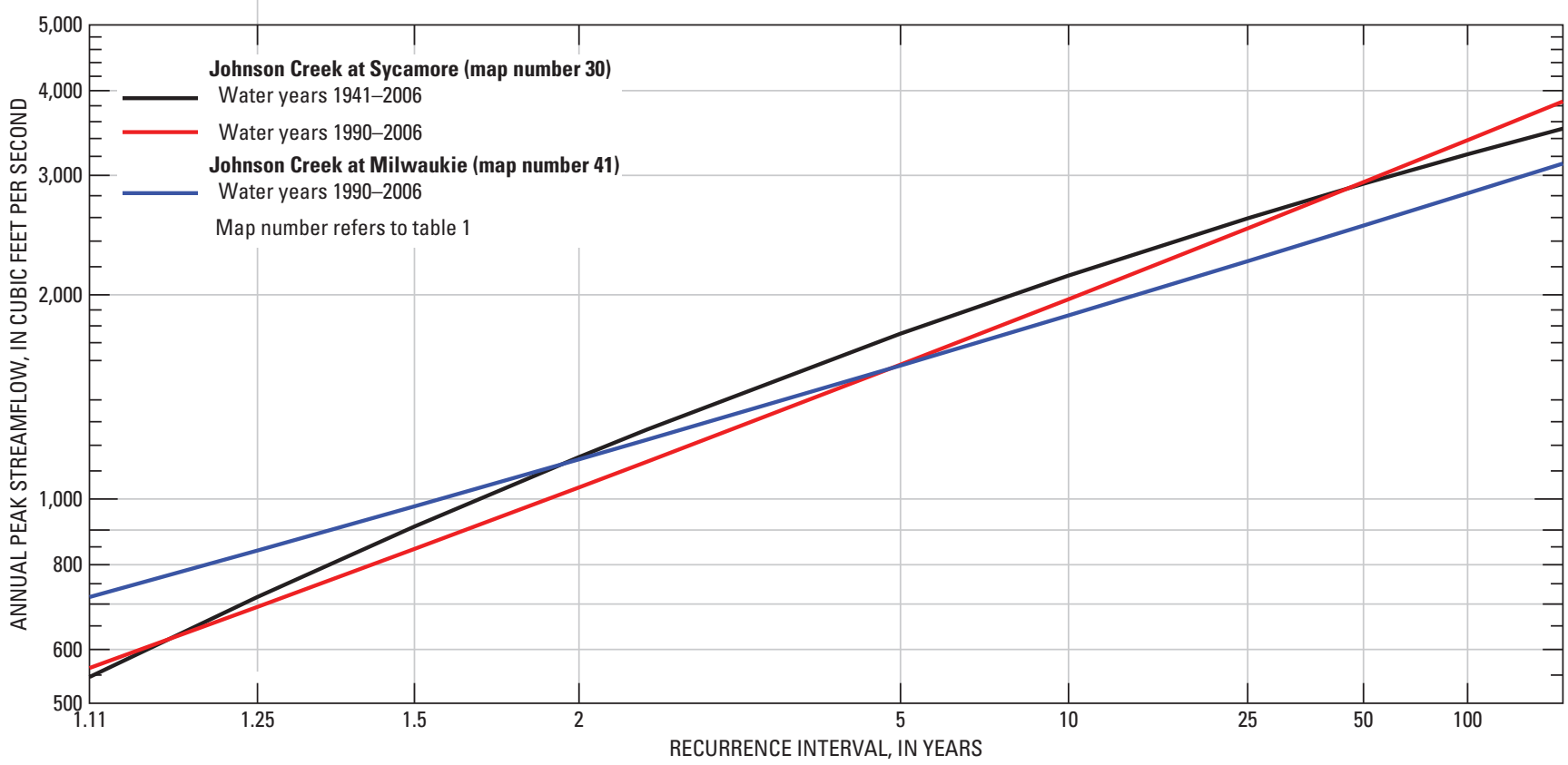

Figure 21. Flood frequency curves based on log-Pearson Type III probability distribution, Johnson Creek at Sycamore, Oregon, water years 1941-2006 and 1990-2006, and Johnson Creek at Milwaukie, Oregon, water years 1990-2006.

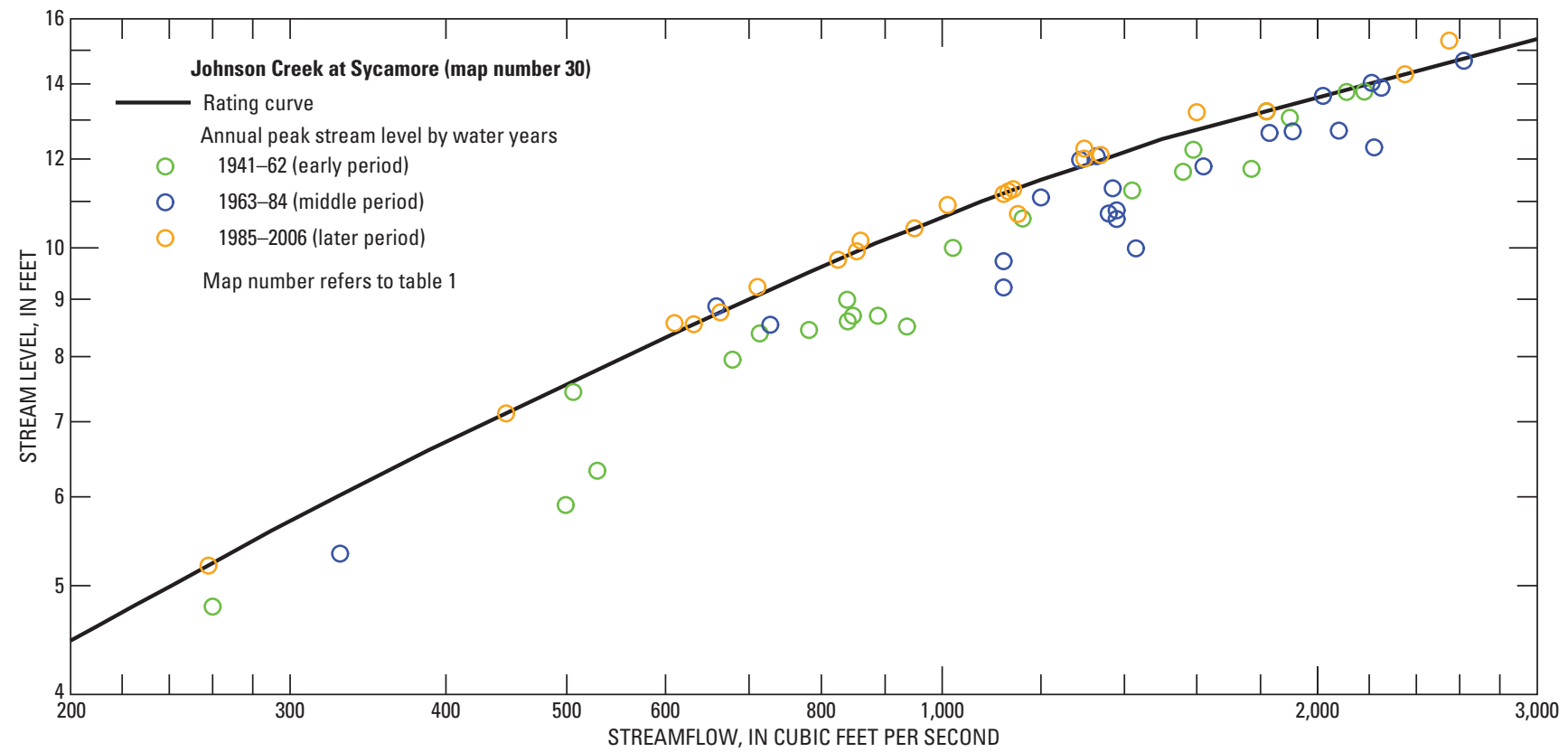

Figure 22. Rating curve in use during water year 2006, and annual peak stream level and streamflow from water years 1941 to 2006, Johnson Creek at Sycamore, Oregon. 
result of the impermanence of vegetation, large wood, and other objects in the stream channel. Streamflow greater than about $1,500 \mathrm{ft}^{3} / \mathrm{s}$ exceeds the capacity of the trapezoidal channel and spills into the overbank area. At this stream level, the stage-discharge rating changes little over time because of the general consistency of the shape and slope of the terrain near the streamflow site. This analysis shows that the stream channel gradually was filled in, but relative to the range of stream level (about $15 \mathrm{ft}$ ) and the time period (66 years), the $1 \mathrm{ft}$ of fill is small. When flows are greater than about $2,000 \mathrm{ft}^{3} / \mathrm{s}$, corresponding to a recurrence interval of 10 years and more, the relation of stream level to streamflow has not changed measurably. This analysis is valid for the Sycamore site only. Other changes to the stream channel elsewhere in the basin may have altered the relation of stream level to streamflow.

The capacity of a stream channel can change naturally over time and may or may not be a result of human activity. Aside from the initial construction of the stream channel in the 1930s (prior to the beginning of streamflow record at the Sycamore site), the largest single change seems to be in 1968 when much of the channel of Johnson Creek was cleared of brush and debris. County work crews cleared the channel in August of that year and extensive clearing along the creek was reported in an article (Johnson Creek Watershed Council, 2006) citing memories of a once young man employed along with "hundreds of Portland boys for the summer" (of 1968), using "two-man saws, axes, brush hooks, etc. ... in an effort to stop the annual flooding." The result of this clearing lasted for several years afterward; now the channel has refilled from an accumulation of vegetation and debris.

Flow duration was used to evaluate trends in high flow of Johnson Creek and indicated little change from WY 1941 to 2006 in the percentage of time a given daily mean flow was exceeded. The period of daily flow record was divided into three equal-length periods: WY 1941-62 (early), WY 1963-84 (middle), and WY 1985-2006 (later) (fig. 19). Flow at a flow duration of 5 percent differed by less than 20 percent between the early, middle, and later periods.
The measure of "flashiness" of the stream was assessed over time by comparing the percentage of days in a given year that the daily mean streamflow was greater than the annual mean streamflow for that year. The period of record at the Sycamore site was again divided into the same early, middle, and later periods defined previously. The annual mean streamflow in the early and later periods was exceeded 29 percent of the time, but the annual mean streamflow in the middle period was exceeded 26 percent of the time. Temporal trends in "flashiness" were assessed using Kendall's tau correlation coefficient. For the period from WY 1941 to 2006, the Kendall tau value was 0.04; however, the trend was not statistically significant as the $p$-value was 0.65 .

The assessment of "flashiness" of Johnson Creek used daily mean (in contrast to instantaneous) streamflow. Comparison of the rate of rise and decline during storms using instantaneous streamflow may produce inaccurate results because of changes in stream-level monitoring instruments at Johnson Creek at Sycamore. From 1940 to 1997, the stream-level sensor consisted of a stilling well with a floatdriven recorder (Rantz and others, 1982, p. 50). Because the stream-level recorder was inundated during high flows many times and the pipe (actually an 8-in. handmade stone culvert) that relayed the stream level to the stilling well occasionally clogged with silt, the hydrograph recorded a delayed response on the rising and falling limb of the hydrograph. The condition of the pipe could only be detected during periodic visits, so many delayed responses may have gone unnoticed. As a result, although the daily mean and peak streamflow may be accurate, the rate of rise and decline of the stream level may not be. In December 1997, the stilling well was replaced with a pressure sensor (Rantz and others, 1982, p. 52) that was much less subject to fouling and tracked the fluctuations in stream level more accurately. Comparison of the potentially erroneous delayed-response hydrograph from earlier times to a later response may lead to an incorrect conclusion about the rate of rise of the stream. 


\section{Implications for Water Quality}

Although the objective of this report is to describe the physical hydrology of the Johnson Creek basin in terms of how water moves in space and time, findings also relate to water quality. Stream temperature responds to air temperature and to groundwater discharge to the stream. These results will help watershed managers design and assess the effectiveness of measures to reduce summer stream temperature. A previous study indicated a positive relation of organochlorine pesticides to suspended sediment in the stream (Tanner and Lee, 2004). Although this study did not involve collection of sediment or contaminant data, analyses provide insight into high flows that typically entrain sediment (and potentially contaminants) in Johnson Creek. An understanding of controlling factors of stream temperature during low flow and runoff response during high flow may help in the decisions made to maintain and improve water quality in the basin.

\section{Stream Temperature}

Fluctuations in the temperature of Johnson Creek and tributaries are a result of human and natural causes. Low summer stream temperature supports more native fish life, whereas warm temperatures may be harmful to many aquatic organisms, raising concern regarding survival of native fish and other wildlife. A return to a stream temperature regime closer to the predevelopment condition would likely encourage a more native aquatic species composition. The effects of human modification in a stream basin generally cause increases in stream temperature compared to a predevelopment condition. Soil compaction decreases infiltration, which decreases groundwater discharge to the creek. Urban development may direct runoff to a combined sewer system, which also decreases groundwater discharge. Removal of vegetative cover and installation of ponds increases direct sunlight to the stream. Water withdrawals for irrigation decrease stream velocity and depth, increasing warming from the atmosphere.

The Total Maximum Daily Load (TMDL) allocation for temperature of Johnson Creek was set in 2006; it provided goals for reduction of summer stream temperature by increasing nearstream shading (Oregon Department of Environmental Quality, 2006). Because of the large geographic scale of the TMDL and lack of information on groundwater discharge to Johnson Creek, the effect of groundwater discharge on stream temperature was not fully explored. This study reports summer stream temperature decreases in areas of groundwater discharge to the stream and increases in open-water areas.
Groundwater inflow to Johnson Creek was identified by seepage measurements (fig. 4). A similar stream temperature is shown in figure 7 between RM 7.8 and 5.5, where little groundwater enters the stream. In contrast, groundwater discharge between RM 5.5 and 3.2 contributed to a decrease in the temperature of Johnson Creek of about $2-3^{\circ} \mathrm{C}$.

Stream temperature can increase in ponded and openwater areas. Although the flow of Crystal Springs Creek originates as cool groundwater discharge, this stream warms because of exposure to relatively large and shallow open-water areas. Summer warming between the site at Bybee Boulevard (map number 39) and the site at the mouth of Crystal Springs Creek (map number 40) is a result of the configuration of the stream channel in Westmoreland Park where the stream flows through a shallow pond. The 7-day moving average of the daily maximum stream temperature in 2005 is shown in figure 23. Warming of Crystal Springs Creek between the Bybee site and the site at the mouth of the creek is about $2^{\circ} \mathrm{C}$.

The thermal effect of tributary inflows to Johnson Creek depends largely on the relative volume of flow. Although summer temperature of Kelley Creek (map number 29) is low compared to Johnson Creek (fig. 23), streamflow also is low compared to Johnson Creek. Kelley Creek, entering Johnson Creek between the Gresham (map number 26) and Sycamore (map number 30) sites, probably has little effect on stream temperature at the Sycamore site. In contrast, Crystal Springs Creek contributes most of summer streamflow of Johnson Creek at Milwaukie (map number 41) (fig. 4). Summer temperature of Crystal Springs Creek at the mouth (map number 40) usually exceed that of Johnson Creek at Milwaukie (fig. 23). Much of the $1-2^{\circ} \mathrm{C}$ increase in the temperature of Johnson Creek between the Sycamore and Milwaukie sites is attributed to inflow from Crystal Springs Creek.

Summer temperature of Johnson Creek is largely controlled by air temperature. Comparison of stream temperature to air temperature during the warm-weather period (from May to October) of each year provides a reliable relation. A regression relation was developed for each year. The 7-day moving average of the average of the daily maximum and minimum air temperature at the Portland Airport (Oregon Climate Service, 2007) was compared to the 7-day average of the maximum stream temperature at the Gresham and Milwaukie sites. This relation was fairly consistent within each year at each site. The period of record at the Gresham site was from 1999 to 2006, and the average $r^{2}$ value for each year was 0.89 . The record at the Milwaukie site began in 1998, and the average $r^{2}$ value was 0.90 . 


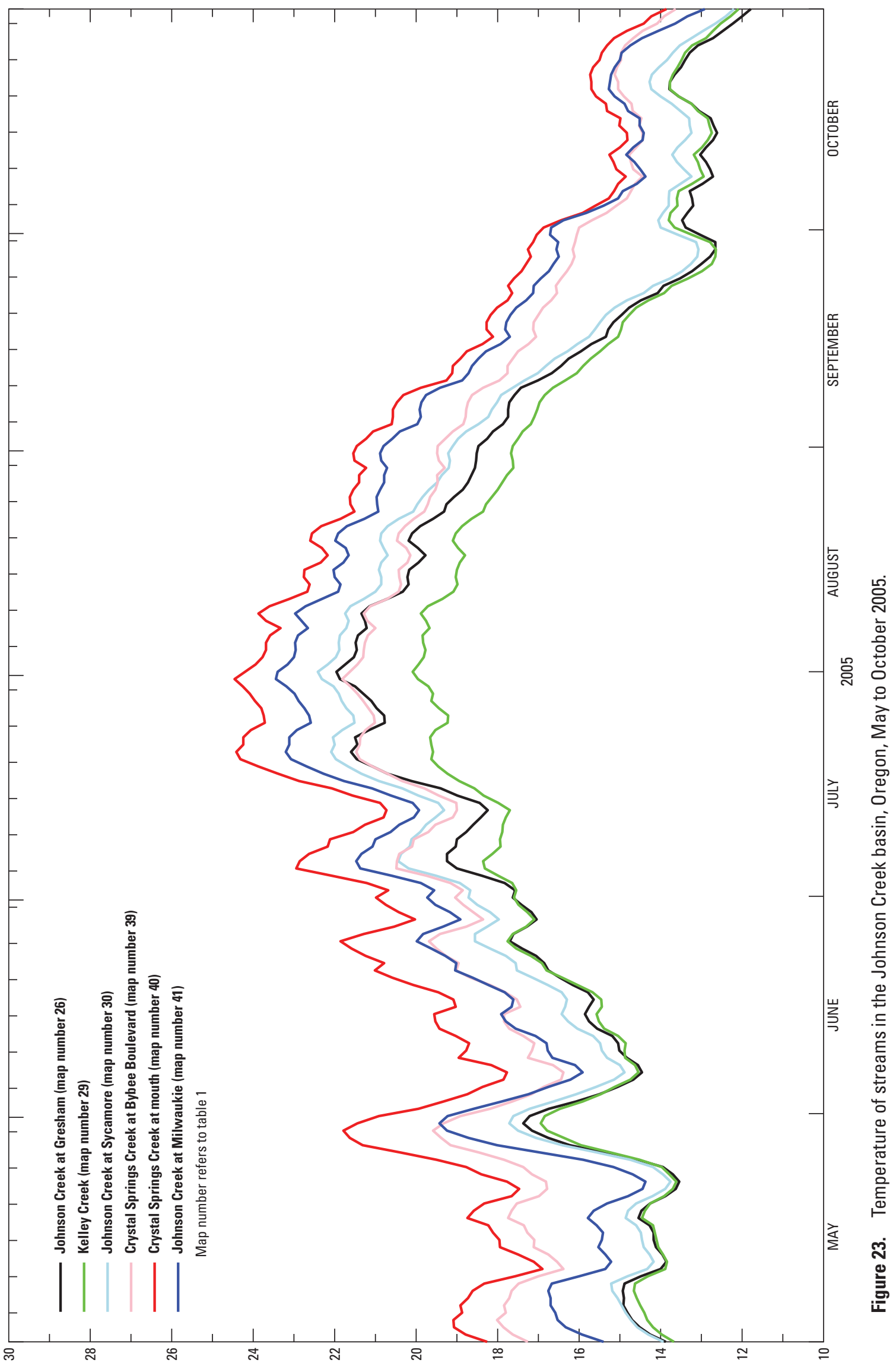


Although the relation of air temperature to stream temperature was fairly consistent from year to year at the Gresham site, the relation at the Milwaukie site was more variable. Estimated stream temperatures resulting from an average air temperature of $22^{\circ} \mathrm{C}$ are shown in figure 24 . At the Gresham site, the predicted stream temperature at that air temperature varied by less than $1^{\circ} \mathrm{C}$ from 1999 to 2006. At the Milwaukie site, a shift from the 1998 to 1999 period to the 2000-2006 period indicated warmer stream temperature for a given air temperature. The shift is attributed to the large decrease in groundwater discharge and subsequent reduction in flow of Crystal Springs Creek. The streamflow of Crystal Springs Creek in 1998 and 1999 was about $17 \mathrm{ft}^{3} / \mathrm{s}$ (fig. 2). Streamflow of Crystal Springs Creek ranged from about 10 to $14 \mathrm{ft}^{3} / \mathrm{s}$ from 2000 to 2006 . This decrease in streamflow resulted in decreased stream velocity, and overall, greater warming in open-water areas of Crystal Springs Creek, resulting in warming of Johnson Creek at the Milwaukie site for a given air temperature. The summer temperature of Johnson Creek at the Milwaukie site at an average air temperature of $22^{\circ} \mathrm{C}$ increased by about $1.5^{\circ} \mathrm{C}$ in the 2000 2006 period compared to the 1998-99 period.

The thermal effect of groundwater discharge and openwater areas on stream temperature may provide insight into meeting stream-temperature standards, informing landuse decisions, and focusing restoration efforts. Land-use decisions that foster increased infiltration (and subsequent groundwater discharge), limit instream withdrawals, and increase nearstream shading may improve the summer temperature regime in Johnson Creek. Restoration efforts focused on elimination of instream ponds and increases in tree canopy particularly in areas of highest summer flows may lead to decreased summer stream temperature.
Continued monitoring of groundwater levels, of streamflow, of temperature, and tracking the many restoration activities underway in the Johnson Creek basin may provide insight into the effectiveness of measures taken to achieve stream temperature goals.

\section{Sediment and Other Contaminants}

The area of the Johnson Creek basin upstream of the Sycamore site contributes more streamflow per-unit-area than the area below this site, where peak flow and volume was large relative to peak streamflow and volume as measured at the Milwaukie site, considering the increase in drainage basin size. Sediment can be a water-quality concern causing problems for fish and other wildlife. Tanner and Lee (2004) showed a relation between organochlorine pesticides and suspended sediment in Johnson Creek. A higher concentration of pesticides per unit of sediment was measured in the area of the basin upstream of the Palmblad Road site (map number 25) compared to the area of the basin upstream of the Sycamore (map number 30) and Milwaukie (map number 41) sites. These results show the importance of managing runoff and minimizing entrainment of sediment in Johnson Creek, particularly in the upper basin.

Land-use activities are part of development in urban, agricultural, and previously undisturbed settings in the Johnson Creek basin. Understanding the transfer of precipitation on the landscape to streamflow, and the sources and fate of sediment and other contaminants in the basin will aid jurisdictions in making land-use decisions for protection of water quality.

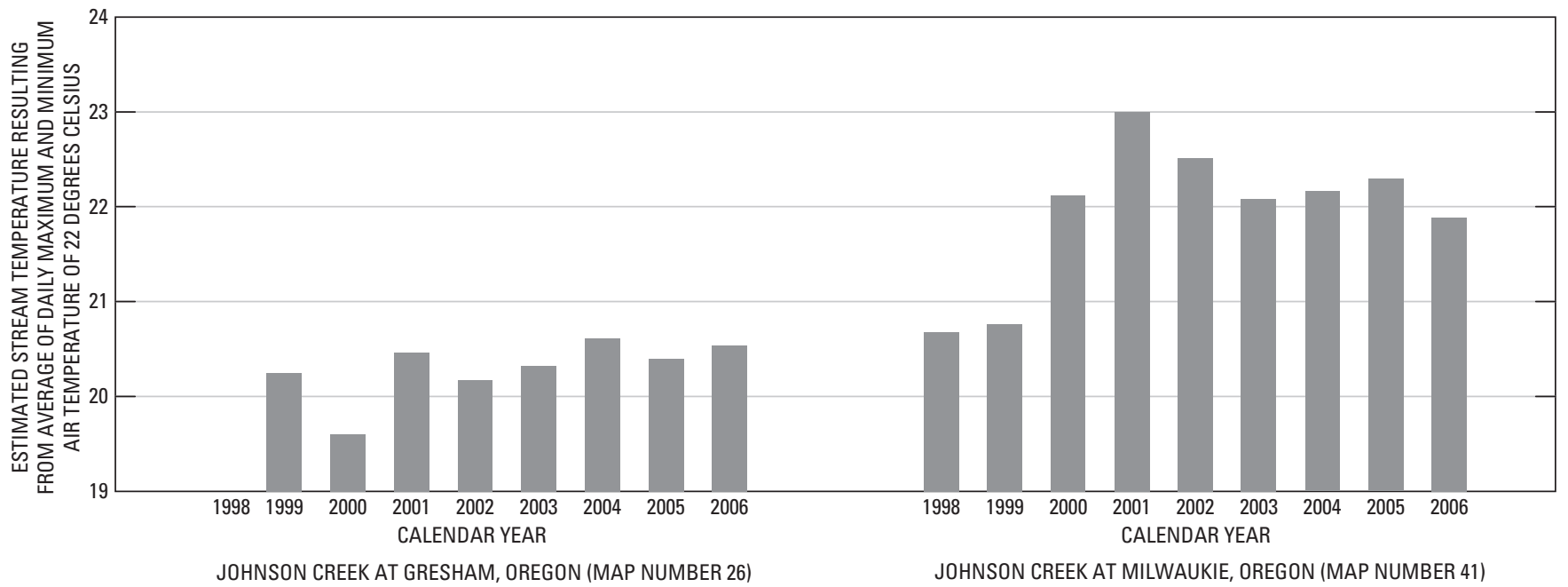

Figure 24. Estimated temperature of Johnson Creek at Gresham, Oregon, and Johnson Creek at Milwaukie, Oregon, based on air temperature at the Portland Airport, Oregon (site number 356751), 1998-2006. Map numbers refer to table 1. 


\section{Potential Future Studies}

This study provides a basis for potential future investigation to enhance our knowledge of the Johnson Creek basin hydrologic system and of the possible effects of land-use changes in the basin. For example, further studies to examine the groundwater flow system could provide information about contributing areas and an insight into the relation between springs and streams within the Johnson Creek basin and throughout the Portland metropolitan area. The installation of a broader network of monitoring wells and development of a fine grid flow model are two efforts that would be of use in gaining a better understanding of the area. Installation of more wells distributed throughout the basin and adjacent areas, with data collection on a decade time-scale would provide the data necessary for increased understanding of groundwater flow and of groundwater interaction with Johnson Creek and tributary streams. And the fine-grid flow model could provide a finer discretization than was previously possible with the coarse-grid regional model made in the 1990s (Morgan and McFarland, 1996).

Identification of groundwater contributing areas of features such as Crystal Springs Creek and Holgate Lake would allow for better determination of causes for variations in streamflow and water levels and provide for greater opportunities for resource protection. Specific to Crystal Springs Creek, further investigation into trends in water levels in wells could lead to better understanding of fluctuations in streamflow. Better understanding of the connection of the aquifer in the Westmoreland Park area to Crystal Springs Creek, Johnson Creek, and the Willamette River, could provide insight into water-level fluctuations in this area. A more detailed analysis of water levels, streamflow, and an elevation survey of the key components in the Westmoreland Park area, including springs, wells, and the creek, also would contribute to an understanding of water level fluctuations.

The groundwater flow system in the volcanic buttes on the southern side of the Johnson Creek basin is not well understood. Dense urban development of this area could lead to negative effects on the hydrology of this area of the basin. Refinements in knowledge of the groundwater flow system and understanding of water uses in the basin could provide guidance to managers on the effects of present and future water withdrawals, and on the effects of land-use changes on base flows of the creeks in this area of the basin.

In the surface-water realm, future study could provide understanding of runoff characteristics of upland areas, particularly on the southern side of the basin, and especially relative to future urban expansion. Analysis of the impact of "green" development, where stormwater is infiltrated onsite, could be compared in a paired-basin study to assess the effectiveness of these measures on flood frequency. From a historical perspective, analyses could be made of the impact of past land-use practices, such as stormwater-disposal methods, on stream response.

Numerous nearstream restoration projects have been completed in the Johnson Creek basin, and more are planned in the coming decades. Several projects involve returning the constructed trapezoidal stream channel to a more natural configuration. The effect of these projects on moderation of high flows and augmentation of groundwater recharge through use of overbank and backwater areas has not been determined. Continued flow monitoring could yield understanding of possible changes in peak streamflow and peak volume. Additional time-of-travel (dye-tracer) studies could provide insight into the effectiveness of the restored features in terms of the timing and dispersive characteristics of the stream.

High stream temperature and sediment (and sedimenttransported contaminants) are problems for water quality in the Johnson Creek basin. Future studies could provide understanding of the effect of measures to reduce thermal loading, such as revegetation, removal of instream ponds, and securing instream water rights. Channel-modification measures underway in 2008 may have an effect on the transport and deposition of sediment in the basin. Understanding of the effect of these changes on sediment transport processes may help guide future restoration work in the Johnson Creek basin.

\section{Summary}

Hydrologic responses to greater than average precipitation in the Johnson Creek basin in water years (WY) 1996-1997 resulted in the flooding of Johnson Creek, elevated groundwater levels, and, over the following several years, increased groundwater discharge to springs. Although the precipitation during distinct storm events resulted in a rise and fall of streamflow on the scale of hours to days, the back-to-back high annual precipitation in WY 1996-1997 led to a response of the groundwater system that lasted for months to years. This study was prompted by inquiry into the causes of floods from increased spring discharge and from an elevated water table, and by a need to better understand spatial and temporal trends in annual, low, and high streamflow of Johnson Creek. The U.S. Geological Survey began the cooperative study in 1997 with the city of Portland. In 2000 the cities of Gresham and Milwaukie and Clackamas County Water Environment Services joined the cooperative study, followed in 2002 by Multnomah County. 
New information was collected for this study, and was analyzed in context with previous studies as well as longterm hydrologic data. New data consisted of a network of groundwater level measurements (including continuous water-level records), numerous streamflow measurements, and continuous records of streamflow and stream temperature.

The average annual total precipitation from WY 1911 to 2006 was about 37 in./yr. Precipitation WY 1996 was 54.7 in., followed by a record $58.7 \mathrm{in}$. in WY 1997. The 3-year moving average annual precipitation in WY 1997, WY 1998, and WY 1999 was the greatest since recordkeeping began. The large inflow (recharge) led to a large outflow (discharge) from the groundwater system to surrounding streams.

Results from water-table mapping and from a regional groundwater flow model of the Portland basin from previous USGS studies indicate that groundwater and surface-water flow divides are not necessarily coincident for the Johnson Creek basin, implying that in some areas of the Johnson Creek basin water that recharges the groundwater system flows out of the basin and discharges to major rivers such as the Sandy, Columbia, or Willamette Rivers. The greater relative discharge observed in the lower reaches of the Johnson Creek basin compared to the upper and middle reaches may be caused by groundwater flow out of the basin in the upper and middle reaches resulting in relatively low base flows in Johnson Creek compared to what might be expected from precipitation amounts in the basin.

Groundwater levels in wells open to the surficial aquifer in the Johnson Creek basin fluctuate generally in a sinusoidal annual pattern in which water levels rise in response to autumn and winter rains and decline during the relatively dry and warm spring and summer seasons. Toward the west, waterlevel fluctuations are damped in magnitude and delayed in time relative to precipitation. In the western area of the basin, water levels in the Westmoreland Park area wells, which are open to a former alluvial channel of either the Clackamas or Willamette Rivers, or both, respond quickly to precipitation and to the levels of the Willamette River and Johnson Creek.

Flooding of Crystal Springs Creek, first recorded in 1997, was caused by elevated groundwater levels and associated increase in groundwater discharge to the springs and the creek. Comparisons made between streamflow of Johnson Creek at Milwaukie and streamflow of Crystal Springs Creek indicated that the high flows of Crystal Springs Creek began in 1996. Comparison of streamflow and precipitation (annual and 3-year moving average) indicated that the relatively high flows of Crystal Springs Creek from 1996 to 1999 probably had not occurred since the channel modifications were made in 1936 during construction of Westmoreland Park, and possibly not since precipitation records began in 1911. A relation was developed between the groundwater level in a well near the springs and streamflow of Crystal Springs Creek in the Reed College area and at the mouth of the creek, enabling prediction of high and low streamflow of Crystal Springs Creek based on groundwater level.'
The appearance of Holgate Lake and occasional flooding in the surrounding area was the result of the shallow water table. Flooding was related to high precipitation years. Groundwater monitoring that began in 1998 and lake-level monitoring that began in 1999 indicated that the lake levels were similar in height to groundwater levels in a nearby well and followed the same pattern of rise and fall. A relation was developed providing some capability to anticipate flooding from Holgate Lake based on early season (autumn to winter) precipitation and antecedent groundwater levels.

Annual, low, and high streamflows were analyzed spatially and temporally using daily mean and annual peak flows of Johnson Creek, and where applicable, of a nearby basin. On an annual basis, streamflow varies across the basin according to several factors. Precipitation is greater in the higher elevation area of the basin. Depending on the direction of groundwater flow and variations in groundwater flow direction at depth, recharge within the surface-water contributing area of the Johnson Creek basin may discharge to Johnson Creek or may discharge to rivers outside of the basin. Some runoff is intercepted by the combined sewer system and is routed out of the basin. Runoff per unit area was greatest in the upper basin, where the average (from WY 1999 to 2006) was 25.3 in., compared to 18.5 and 12.1 in. in the middle and lower basin, respectively. Similarly, runoff as a fraction of precipitation also decreased, where 45, 37, and 28 percent of precipitation resulted in runoff from the upper, middle, and lower areas of the basin, respectively. About half of the increase in annual mean streamflow from the middle to the lower area of the basin during this period was from Crystal Springs Creek.

Low flows varied from year to year, primarily caused by fluctuations in groundwater discharge to Johnson Creek, although low flows were apparently affected by an unidentified water use between 1955 and 1977 as well. Seepage measurements indicated minimal gains in streamflow upstream of RM 5.5 and increased gains toward the mouth of Johnson Creek. Streamflow records indicated minimal increases in low flow between the Gresham and Sycamore sites from 1998 to 2006. Most of the increase in low flows between the Sycamore and Milwaukie sites is attributable to Crystal Springs Creek. Low flows may be exacerbated by minimal groundwater discharge to the stream in the upper and middle areas of the basin, where Johnson Creek captures little groundwater flow. In these areas, groundwater flow leaving the drainage basin is inferred from water-table mapping and previous modeling results. A comparison of low flows of Johnson Creek at Sycamore from 1941 to 2006 to low flows of the Little Sandy River indicated that water withdrawals from Johnson Creek during the low-flow period from 1955 to 1977 may have been the cause of a 50 percent decrease in summer flows during this period.

High flows result from runoff from the land surface and depend on precipitation volume and intensity. Although the magnitude of high flows masks groundwater discharge to the stream during rainy periods, interception by the combined 
sewer system, UIC systems, and a permeable landscape moderates high flows in the lower area of the Johnson Creek basin. The difference in high flow of Johnson Creek at the Sycamore and Milwaukie sites, in terms of the magnitude of peak streamflow and volume of storm runoff, is relatively small considering the increase in drainage basin size.

Temporal trends in flow typically associated with increasing urban development generally were absent in Johnson Creek. Annual flow as a fraction of annual precipitation, low flow (with the exception of unusually low flows from 1955 to 1977), annual peak flows, and the percentage of days in a given year when the daily mean streamflow is greater than the annual mean streamflow, exhibited no trend from 1941 to 2006 . The absence of a temporal trend does not mean that the hydrology of the Johnson Creek basin has been unaffected by human occupation because much of the agricultural, residential, and urban development including the extensive channelmodification of the lower $11 \mathrm{mi}$ of Johnson Creek predated data collection in the basin. Because of the management of stormwater in urban areas, most urbanization additionally was not associated with simple piping of stormwater to the creek. Drywells and other UIC systems have been in use for decades, taking advantage of the infiltration capacity of permeable subsurface deposits in the urban areas. Continued development of innovative onsite methods of stormwater disposal, particularly in upland areas, may lead to decreased peak flows and enhanced recharge to the groundwater system.

Summer temperature of streams in the Johnson Creek basin is affected by the cooling effects of groundwater discharge and by warming from ponded and open-water areas. Although the source of water for Crystal Springs Creek is spring flow, warming due to instream constructed ponds results in a temperature in Crystal Springs Creek which is greater than that in Johnson Creek. Because Crystal Springs Creek accounts for most of the flow in Johnson Creek downstream from its confluence, it warms Johnson Creek during summertime.

High flow of Johnson Creek may entrain sediment and sediment-borne contaminants. Several factors indicate that sediment yield of the basin may be sensitive to conditions in the upper area of the basin. These factors include generally higher precipitation, greater slopes, a dense network of roads and ditches associated with agricultural and rural residential land uses, and a relative abundance of sources of sediment and sediment-borne contaminants compared to the relatively low relief, urban areas of the lower basin.

Continued study of the Johnson Creek basin will provide insight into the response of the hydrology to land-use changes. In particular, runoff from newly acquired areas for urban development in the upper area of the basin may be particularly sensitive to changes in land use.

\section{Acknowledgments}

The authors wish to thank cooperating agencies and their staff including Maggie Skenderian and Frank Wildensee (city of Portland), Carrie Pak (formerly of city of Gresham), Lynne Kennedy and Torrey Lindbo (city of Gresham), the late George MacGregor (city of Milwaukie), Ela Whelan (formerly of Clackamas County), Andrew Swanson and John Nagy (Clackamas County's Water Environment Services), and Kim Peoples (Multnomah County). Special thanks go to Mark Liebe (city of Portland) for inspiration and excellent insight regarding groundwater flow in the basin, and to Ivy Francis (formerly of the city of Portland) for the original request for assistance in 1997. Land owners throughout the basin provided access to properties for data collection during the study. Tiffany Jacklin and Melanie North (USGS) provided data base support. USGS personnel, beginning in the early 1940s provided the basic (and essential) data used in the interpretations developed in this report.

\section{References Cited}

Anderson, C.W., Rinella, F.A., and Rounds, S.A., 1996, Occurrence of selected trace elements and organic compounds and their relation to land use in the Willamette River basin, Oregon, 1992-94: U.S. Geological Survey Water-Resources Investigations Report 96-4234, 68 p., accessed May 28, 2008, at http://pubs.er.usgs.gov/usgspubs/ wri/wri964234

Beeson, M.H., Tolan, T.L., and Madin, I.P., 1989, Geologic map of the Lake Oswego quadrangle, Clackamas, Multnomah, and Washington Counties, Oregon: Oregon Department of Geology and Mineral Industries Map GMS-59, 1 sheet, scale 1:24,000, accessed May 28, 2008, at http://www.oregongeology.com/sub/publications/GMS/ gms059.pdf

Chang, Heejun, 2006, Comparative streamflow characteristics in urbanizing basins in the Portland Metropolitan Area, Oregon, USA: Hydrological Processes, v. 21, no. 2, p. 211-222, accessed October 31, 2008, at http://dx.doi. org/10.1002/hyp.6233

Chestnut, C.R., 1997, Summer Flooding from Crystal Springs Creek Bedevils Westmoreland: Oregonian, July 24, 1997.

Collins, C.A., and Broad, T.M., 1993, Estimated average annual ground-water pumpage in the Portland basin, Oregon and Washington, 1987-1988: U.S. Geological Survey Water-Resources Investigations Report 91-4018, 26 p., accessed May 28, 2008, at http://pubs.er.usgs.gov/pubs/wri/ wri914018 
Conlon, T.D., Wozniak, K.C., Woodcock, Douglas, Herrera, N.B., Fisher, B.J., Morgan, D.S., Lee, K.K., and Hinkle, S.R., 2005, Ground-water hydrology of the Willamette basin, Oregon: U.S. Geological Survey Scientific Investigations Report 2005-5168, 83 p., 1 pl., accessed May 28, 2008, at http://pubs.er.usgs.gov/pubs/sir/sir20055168

Cooper, R.M., 2005, Estimation of peak discharges for rural, unregulated streams in western Oregon: U.S. Geological Survey Scientific-Investigations Report 2005-5116, 134 p., accessed May 28, 2008, at http://pubs.er.usgs.gov/ usgspubs/sir/sir20055116

Dames and Moore, 1998, Draft Final Crystal Springs watershed assessment-Prepared for the City of Portland Bureau of Environmental Services: Portland, Oregon, June, 1998, 75 p., plus appendixes.

Dillin, J.F., Jr., 1997, Citizens Seek Solutions to Crystal Springs Creek Flooding: Sellwood Bee, September 1997.

Edwards, T.K., 1992, Water quality and flow data for the Johnson Creek basin, Oregon, April 1988 to January 1990: U.S. Geological Survey Open-File Report 92-73, 29 p., accessed May 29, 2008, at http://pubs.er.usgs.gov/ usgspubs/ofr/ofr9273

Edwards, T.K., 1994, Assessment of surface-water quality and water-quality control alternatives, Johnson Creek basin, Oregon: U.S. Geological Survey Water-Resources Investigations Report 93-4090, 50 p., accessed May 29, 2008, at http://pubs.er.usgs.gov/usgspubs/wri/wri934090

Edwards, T.K., and Curtiss, D.A., 1993, Preliminary evaluation of water-quality conditions of Johnson Creek, Oregon: U.S. Geological Survey Water-Resources Investigations Report 92-4136, 15 p., accessed May 29, 2008, at http://pubs.er.usgs.gov/usgspubs/wri/wri924136

Flynn, K.M., Kirby, W.H., and Hummel, P.R., 2006, User’s manual for program PeakFQ annual flood-frequency analysis using Bulletin 17B guidelines: U.S. Geological Survey Techniques and Methods 4B4, 42 p., accessed May 29, 2008, at http://pubs.er.usgs.gov/usgspubs/tm/ $\underline{\mathrm{tm} 4 \mathrm{~B} 4}$

Franke, O.L., Reilly, T.E., Pollock, D.W., and LaBaugh, J.W., 1998, Estimating areas contributing recharge to wellsLessons from previous studies: U.S. Geological Survey Circular 1174, 14 p., accessed October 30, 2008, at http:// pubs.er.usgs.gov/usgspubs/cir/cir1174

Freeze, R.A., and Cherry, J.A., 1979, Groundwater: Englewood Cliffs, N.J., Prentice-Hall, 604 p.

Gresham Outlook, 1949, Gilbert Homes Covered by Temporary Lake: Gresham Outlook, March 3, 1949, photograph and caption, p. 1.
Gresham Outlook, 1969, S.E. Long Street Residents Seeking Help from County: Gresham Outlook, February 6, 1969, p. 3.

Helsel, D.R., and Hirsch, R.M., 2002, Statistical methods in water resources: U.S. Geological Survey Techniques of Water-Resources Investigations, book 4, Hydrologic Analysis and Interpretation, chap. A3, 523 p., accessed May 29, 2008, at http://pubs.er.usgs.gov/pubs/twri/ $\underline{\text { twri04A3 }}$

Hinkle, S.R., and Snyder, D.T., 1997, Comparison of chlorofluorocarbon-age dating with particle-tracking results of a regional ground-water flow model of the Portland basin, Oregon and Washington: U.S. Geological Survey Water-Supply Paper 2483, 47 p., accessed May 29, 2008, at http://pubs.er.usgs.gov/pubs/wsp/wsp2483

Hogenson, G.M., and Foxworthy, B.L., 1965, Ground water in the East Portland area, Oregon: U.S. Geological Survey Water Supply Paper 1793, 78 p., accessed May 29, 2008, at http://pubs.er.usgs.gov/pubs/wsp/wsp1793

Insightful Corporation, 2005, S-PLUS® 7.0.6, Release for Windows, December 2005, accessed October 28, 2008, at http://www.insightful.com/support/doc splus win.asp

Johnson Creek Watershed Council, 2006, Within your reach: JCWC Newsletter, v. XIV, no. 2, p. 7.

Jones, M.A., Jones, J.L., and Olsen, T.D., 2000, Groundwater flooding in glacial terrain of southern Puget Sound, Washington: U.S. Geological Survey Fact Sheet FS-111-00, 5 p., accessed May 29, 2008, at http://pubs.er.usgs.gov/ usgspubs/fs/fs 11100

Kennedy, E.J., 1990, Levels at streamflow gaging stations: U.S. Geological Survey Techniques of Water-Resources Investigations, book 3, Applications of Hydraulics, chap. A19, 26 p., accessed May 29, 2008, at http://pubs.er.usgs. gov/usgspubs/twri/twri03A19

Konrad, C.P., and Booth, D.B., 2002, Hydrologic trends associated with urban development for selected streams in the Puget Sound basin, Western Washington: U.S. Geological Survey Water-Resources Investigations Report 02-4040, 40 p., accessed May 29, 2008, at http:// pubs.usgs.gov/wri/wri024040/

Laenen, Antonius, 1980, Storm runoff as related to urbanization in the Portland, Oregon-Vancouver, Washington area: U.S. Geological Survey Open-File Report 80-689, 71 p., accessed May 29, 2008, at http:// pubs.er.usgs.gov/usgspubs/ofr/ofr80689 
Laenen, Antonius, and Risley, J.C., 1997, Precipitation-runoff and streamflow-routing models for the Willamette River basin, Oregon: U.S. Geological Survey Water-Resources Investigations Report 95-4284, 197 p., accessed May 29, 2008, at http://pubs.er.usgs.gov/usgspubs/wri/wri954284

Lee, K.K., 1995, Stream velocity and dispersion characteristics determined by dye-tracer studies on selected stream reaches in the Willamette River basin, Oregon: U.S. Geological Survey Water-Resources Investigations Report 95-4078, 39 p., accessed May 29, 2008, at http:// pubs.er.usgs.gov/usgspubs/wri/wri954078

Lee, K.K., and Risley, J.C., 2002, Estimates of ground-water recharge, base flow, and stream reach gains and losses in the Willamette basin, Oregon: U.S. Geological Survey WaterResources Investigations Report 01-4215, 52 p., accessed May 29, 2008, at http://pubs.er.usgs.gov/usgspubs/wri/ wri014215

McCarthy, K.A., and Anderson, D.B., 1990, Ground-water data for the Portland basin, Oregon and Washington: U.S. Geological Survey Open-File Report 90-126, 56 p., accessed May 29, 2008, at http://pubs.er.usgs.gov/pubs/ofr/ ofr90126

McCarthy, K.A., and Gale, R.W., 1999, Investigation of the distribution of organochlorine and polycyclic aromatic hydrocarbon compounds in the lower Columbia River using semipermeable membrane devices: U.S. Geological Survey Water-Resources Investigations Report 99-4051, 136 p., accessed May 29, 2008, at http://pubs.er.usgs.gov/usgspubs/ wri/wri994051

McFarland, W.D., and Morgan, D.S., 1996, Description of the ground-water flow system in the Portland basin, Oregon and Washington: U.S. Geological Survey Water Supply Paper 2470-A, 58 p., accessed May 29, 2008, at http://pubs. er.usgs.gov/pubs/wsp/wsp2470A

Metro, 2002, Digital elevation model-Portland, Oregon: Metro Data Resource Center, metadata accessed April 10, 2009, at http://rlismetadata.oregonmetro.gov/display. $\underline{\text { cfm? Meta layer id }=1956 \& D b \text { type }=r l i s}$

Moffatt, R.L., Wellman, R.E., and Gordon, J.M., 1990, Statistical summaries of streamflow data in OregonVolume 1, Monthly and annual streamflow, and flowduration values: U.S. Geological Survey Open-File Report 90-118, 413 p., accessed May 29, 2008, at http:// pubs.er.usgs.gov/usgspubs/ofr/ofr90118

Morgan, D.S., and McFarland, W.D., 1996, Simulation analysis of the ground-water flow system in the Portland basin, Oregon and Washington: U.S. Geological Survey Water Supply Paper 2470-B, 83 p., accessed May 29, 2008, at http://pubs.er.usgs.gov/pubs/wsp/wsp2470B
Oregon Climate Service, 2007, Climate data: Corvallis, Oreg., Oregon State University, accessed May 11, 2007, at http:// www.coas.oregonstate.edu/OCS/

Oregon Department of Environmental Quality, 2006, Willamette basin TMDL - Chapter 5, Lower Willamette subbasin: Portland, Oreg., Oregon Department of Environmental Quality, accessed January 4, 2008, at http:// www.deq.state.or.us/wq/tmdls/docs/willamettebasin/ willamette/chpt5lowerwill.pdf

Oregon Water Resources Department (OWRD), 2008, Well database: Salem, Oreg., Oregon Water Resources Department, accessed March 24, 2009, at http://www. oregon.gov/OWRD/PUBS/ToolsData.shtml

Oregonian, 1997, Anger Overflows near Pesky Lake: Oregonian, February 3, 1997.

PRISM Group, 2007, Oregon State University, accessed April 10, 2009, at http://prism.oregonstate.edu/products/ viewer.phtml?file=/pub/prism/us_30s/grids/ppt/Normals/ us_ppt 1971 2000.14.gz\&year $=1971 \_2000 \&$ vartype $=p p t$ \&month $=14 \&$ status $=$ final

Rantz, S.E., and others, 1982, Measurement and computation of streamflow. Volume 1. Measurement of stage and discharge. Volume 2. Computation of discharge.: U.S. Geological Survey Water Supply Paper 2175, 631 p., accessed May 29, 2008, at http://pubs.usgs.gov/wsp/ wsp2175/

Rutledge, A.T., 1998, Computer programs for describing the recession of ground-water discharge and for estimating mean ground-water recharge and discharge from streamflow data-Update: U.S. Geological Survey WaterResources Investigations Report 98-4148, 43 p., accessed May 29, 2008, at http://pubs.usgs.gov/wri/wri984148

Searcy, J.K., 1959, Flow-duration curves-Manual of hydrology, Part 2, Low-flow techniques: U.S. Geological Survey Water-Supply Paper 1542-A, 33 p., accessed May 29, 2008, at http://pubs.er.usgs.gov/usgspubs/wsp/ wsp1542A

Sellwood Bee, 1997, Neighbors Pitch in and Pull Weeds in Crystal Springs Creek: Oregonian, October 1997, p. 1.

Snyder, D.T., 2008, Estimated depth to ground water and configuration of the water table in the Portland, Oregon area: U.S. Geological Survey Scientific Investigations Report 2008-5059, 40 p., accessed August 25, 2008, at, http://pubs.usgs.gov/pubs/sir/2008/5059 
Snyder, D.T., Morgan, D.S., and McGrath, T.S., 1994, Estimation of ground-water recharge from precipitation, runoff into drywells, and on-site waste-disposal systems within the Portland basin, Oregon and Washington: U.S. Geological Survey Water-Resources Investigations Report 92-4010, 34 p., accessed May 29, 2008, at http://pubs. er.usgs.gov/pubs/wri/wri924010

Stonestrom, D.A., and Constantz, Jim, eds., 2003, Heat as a tool for studying the movement of ground water near streams: U.S. Geological Survey Circular 1260, 96 p., accessed May 29, 2008, at http://pubs.er.usgs.gov/ usgspubs/cir/cir1260

Tanner, D.Q., and Lee, K.K., 2004, Organochlorine pesticides in the Johnson Creek basin, Oregon, 1988-2002: U.S. Geological Survey Scientific Investigations Report 20045061, 42 p., accessed May 29, 2008, at http://pubs.er.usgs. gov/usgspubs/sir/sir20045061

Taylor, C.J., and Alley, W.M., 2002, Ground-water-level monitoring and the importance of long-term water-level data: U.S. Geological Survey Circular 1217, 68 p., accessed October 27, 2008, at http://pubs.er.usgs.gov/usgspubs/cir/ $\underline{\operatorname{cir} 1217}$

Trimble, D.E., 1963, Geology of Portland, Oregon and adjacent areas-A study of Tertiary and Quaternary deposits, lateritic weathering profiles, and of Quaternary history of part of the Pacific Northwest: U.S. Geological Survey Bulletin 1119, 119 p., accessed October 28, 2008, at http:// pubs.er.usgs.gov/usgspubs/b/b1119

U.S. Department of Agriculture Natural Resources Conservation Service, 2007, Oregon soil survey dataSoil survey for Multnomah and Clackamas Counties: Washington, D.C., U.S. Department of Agriculture, accessed June 20, 2007, at http://www.or.nrcs.usda.gov/ pnw_soil/or_data.html

U.S. Geological Survey, [2009], Ground-water data for Oregon: Washington, D.C., U.S. Geological Survey, accessed March 24, 2009, at http://waterdata.usgs.gov/or/ nwis/gw

U.S. Interagency Advisory Committee on Water Data, 1982, Guidelines for determining flood flow frequency: U.S. Geological Survey, Bulletin 17B, 183 p., accessed May 29, 2008, at http://water.usgs.gov/osw/bulletin17b/ bulletin 17B.html

U.S. National Oceanic and Atmospheric Administration, 2007, Monthly climate data: Reno, Nev., Western Regional Climate Center, accessed May 29, 2008, at http://www. wrcc.dri.edu/cgi-bin/cliMAIN.pl?wavanc
University of Oregon, 2006, General Land Office MapsDigital Copies of the Cadastral Survey Maps for Oregon, digital images of Township (T) 1 North (N) Range (R) 2 East (E) (1852), T. 1 N. R. 3 E. (1855), T. 1 South (S) R. 1 E. (1852), T. 1 S. R. 2 E. (1854), T. 1 S. R. 3 E. (1855): Eugene, Oreg., University of Oregon, accessed November 2, 2006, at http://libweb.uoregon.edu/map/GIS/Data/ Oregon/GLO/Quadrant 4.htm\#1s

Veeger, A.I., and Johnston, H.E., 1996, Hydrogeology and water resources of Block Island, Rhode Island, with a section on Geology, by B.D. Stone and L.A. Sirkin: U.S. Geological Survey Water-Resources Investigations Report 94-4096, 76 p., accessed October 28, 2008, at http://pubs. er.usgs.gov/usgspubs/wri/wri944096

Wagner, R.J., Boulger, R.W., Jr., Oblinger, C.J., and Smith, B.A., 2006, Guidelines and standard procedures for continuous water-quality monitors - Station operation, record computation, and data reporting: U.S. Geological Survey Techniques and Methods 1-D3, 51 p., accessed May 11, 2007, at http://pubs.usgs.gov/tm/2006/tm1D3/

Waitt, R.B., Jr., 1985, Case for periodic, colossal jökulhlaups from Pleistocene glacial Lake Missoula: Geological Society of America Bulletin, v. 96, no. 10, p. 1271-1286, accessed May 29, 2008, at http://vulcan.wr.usgs.gov/Glossary/ Glaciers/IceSheets/Waitt85GSA/framework.html

Wellman, R.E., Gordon, J.M., and Moffatt, R.L., 1993, Statistical summaries of streamflow data in OregonVolume 2, Annual low and high flow, and instantaneous peak flow: U.S. Geological Survey Open-File Report 93-63, 406 p., accessed May 29, 2008, at http://pubs.er.usgs.gov/ usgspubs/ofr/ofr9363

Wilde, F.D., ed., 2005, Field measurements: U.S. Geological Survey Techniques of Water-Resources Investigations, book 9, chap. A6, accessed May 29, 2008, at http://pubs.water. usgs.gov/twri9A6/

Wilson, W.E., and Moore, J.E., eds., 2003, Glossary of hydrology: Falls Church, Va., American Geological Institute, $248 \mathrm{p}$.

Winter, T.C., Harvey, J.W., Franke, O.L., and Alley, W.M., 1998, Ground water and surface water-A single resource: U.S. Geological Survey Circular 1139, 79 p., accessed May 29, 2008, at http://pubs.er.usgs.gov/usgspubs/cir/cir1139 
Hydrology of the Johnson Creek Basin, Oregon

This page intentionally left blank. 
Publishing support provided by the U.S. Geological Survey

Publishing Network, Tacoma Publishing Service Center

For more information concerning the research in this report, contact the Director, Oregon Water Science Center

U.S. Geological Survey

2130 SW 5th Avenue

Portland, Oregon 97201

http://or.water.usgs.gov 
